UniVERsidAd NACIONAL DE LA PLATA

FACULTAD DE HUMANIDADES Y CIENCIAS DE LA

Educación SECRETARÍA de Posgrado

\title{
Configuración de una "memoria Nepantla" en Borderlands/La Frontera: The New Mestiza de Gloria Anzaldúa
}

\section{Yanet Verenice Cornejo Guzmán}

Tesis para optar por el grado de Maestra en Historia y Memoria Directora Teresa Basile

La Plata, 3 de Mayo de 2019 



\section{Índice}

Agradecimientos 2

Introducción 4

$\begin{array}{ll}\text { CAPÍTULO I } & 13\end{array}$

DE LA NACIÓN A LAS "MEMORIAS FRONTERIZAS”: EL CASO CHICANO 13

$\begin{array}{lll}1.1 & \text { De la nación a las culturas híbridas } & 15\end{array}$

Una mirada sobre el origen de la nación en Ernest Renan 16

Nación y nacionalismo: una pretensión de homogeneidad narrativa 18

Las culturas híbridas que interpelan la homogeneidad de la nación 24

$\begin{array}{ll}\text { Tradicionalismo versus modernización } & 27\end{array}$

1.2 Teorías de la frontera: repensar la memoria y la identidad 32

$\begin{array}{ll}1.3 \text { Memorias en conflicto } & 37\end{array}$

La lengua como escenario de las memorias en pugna 44

¡Si no lo usas se olvida! $\quad 47$

$\begin{array}{ll}1.4 \text { Una mirada a la sociedad chicana } & 48\end{array}$

"Aztlán" en la narrativa chicana $\quad 50$

La compleja asimilación en la sociedad chicana $\quad 53$

La rebeldía del "Pachuco"

El término chicano: una propuesta de identidad $\quad 57$

Las mujeres en la configuración de una narrativa chicana: el caso de Gloria $\begin{array}{ll}\text { Anzaldúa } & 60\end{array}$

CAPÍTULO II $\quad 64$

BORDERLANDS/LA FRONTERA: THE NEW MESTIZA: LA APUESTA POR UNA "MEMORIA NEPANTLA" 64

$\begin{array}{ll}2.1 \text { Borderlborderlands } & 67\end{array}$

Apuntes generales sobre Borderlands... 68

El testimonio en Borderlands... 68

$\begin{array}{ll}2.2 \text { El spanglish y las herencias lingüísticas } & 71\end{array}$

El uso del Code-Switching en Borderlands/La Frontera...

La "lengua rebelde" en el marco de una pedagogía del "control" 81

$\begin{array}{ll}\text { Romper el silencio y ser una "hija de la chingada" } & 87\end{array}$

2.3 Coatlicue-Tonantzin-la Virgen de Guadalupe, la Llorona y la Malinche: $\begin{array}{ll}\text { símbolos de una nueva narrativa chicana } & 91\end{array}$

$\begin{array}{ll}\text { En busca del equilibrio perdido } & 93\end{array}$ 
Coatlicue-Tonantzin-Guadalupe 95

La "Llorona": de la mujer "maldita" a la "rebelde" 100

La Malinche: la mujer "maldita" 104

2.4 Construcción de una "memoria Nepantla" a través de la "Nueva Mestiza" 106

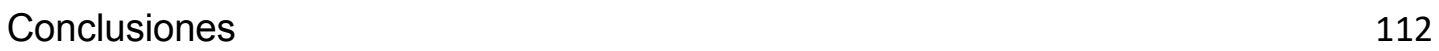

$\begin{array}{ll}\text { Bibliografía } & 115\end{array}$ 



\section{Agradecimientos}

En primer lugar, quiero agradecer a la Dra. Teresa Basile, mi directora de tesis, quien a través de sus agudas observaciones me enseñó a reflexionar de manera exhaustiva sobre mi tema. También me enseñó a escribir de manera clara mis ideas y a no enredarme tanto con el lenguaje. Sé que estos aprendizajes me acompañarán mientras siga pensando y escribiendo. Además, quiero agradecerle porque siguió conmigo a pesar de mi lentitud, mis tiempos tan prolongados para entregar avances, es algo que no sé cómo agradecer, así que sólo puedo reiterar mi admiración.

En segundo lugar, quiero agradecer a mis compañeras y compañeros en Argentina, su presencia fue fundamental para enfrentar las crisis que provoca la distancia del terruño. La extraña sensación de estar disfrutando de otro país, pero a la vez añorar el hogar, solía ser superada gracias a los amigos. Como lo dije en mi tesis de licenciatura y lo reitero en esta: dedico mi tesis a la familia que no elegí y también a la familia que elegí y me ha elegido para compartir el día a día. La lista de nombres sería larga, sólo diré que mis días estuvieron acompañados de mexicanos, argentinos, colombianos y chilenos.

En tercer lugar, quiero agradecerle al equipo administrativo y docente que conforman y conformaron la Maestría en Historia y Memoria (Universidad Nacional de la Plata). Mis aprendizajes durante los dos años que cursé seminarios y conviví con algunos de ustedes me han enseñado a tener una mirada más crítica de mi realidad, de mi contexto mexicano, abrumado por la violencia.

En cuarto lugar, quiero agradecer al Programa de Becas Roberto Carri, porque gracias a sus estímulos económicos fue posible que yo estudiara la Maestría en Historia y Memoria y que viviera en uno de los países que más deseaba conocer por esas idealizaciones que uno en algún momento hace. Cuando solicité la beca estaba acostumbrada a escuchar 
noticias que me sorprendían gratamente sobre Argentina, como la aprobación del matrimonio igualitario (2010) y la discusión sobre si era correcto Ilamar "la presidenta" a quien en ese momento ocupaba la presidencia de la República Argentina, o tenía que ser "la presidente". Desconozco si en Argentina también existió esa discusión, en México se libraron interesantes debates por esta razón.

Por último, quiero hacer una mención especial a mi familia en Estados Unidos, a estas alturas ya son tres hermanos y tres hermanas que viven en aquel país. Ellos han vivido parte de lo que he desarrollado en mi tesis, pues han tenido que cruzar la frontera (la mayoría de ellos de "ilegales") y han tenido que lidiar con comentarios racistas. Aunque algunos ya son residentes, siguen con los miedos de ser "ilegales", creen que ante la mínima falta es posible que les quiten esos papeles que les dan derecho a transitar en un territorio. Así que esta tesis me ayudó a comprender muchas de esas situaciones por las que ellos han pasado y que han marcado sus vidas, pero también las de quienes estamos en México. Mientras hacía la tesis me tocó ver el documental "Los que se quedan" (2008) de Juan Carlos Rulfo y Carlos Hagerman, en donde se retrata y narra el drama desgarrador que es la migración para muchas familias que se quedan y esperan en México. Muchas veces las personas no vuelven a ver a sus seres queridos ni a saber nada de ellos. Desafortunadamente en México el drama migratorio nos alcanza a todos, pero, se podría decir, que soy de las afortunadas, de las que saben dónde viven y de qué viven sus hermanos y hermanas. 


\section{Introducción}

\section{Estado de la cuestión:}

La memoria como preocupación primordial en las sociedades occidentales ha sido uno de los acontecimientos de mayor interés, tanto en el ámbito de la cultura como de la política, al menos desde la segunda mitad del siglo XX. Mientras la modernidad ${ }^{1}$ exhibía una obsesión por el futuro, en la actualidad se observa un notable giro hacia el pasado. Andreas Huyssen resalta que si bien los discursos sobre la memoria fueron impulsados por movimientos sociales y descolonizadores en la década de los sesenta, en los ochenta estas narrativas se intensificaron principalmente en Europa y en Estados Unidos, promovidas por "el debate cada vez más amplio sobre el Holocausto" y "el auge del testimonio". Esta expansión de la memoria, como fenómeno "global", colocó en el centro de las discusiones al "Holocausto como tropos universal del trauma histórico", por eso en distintos contextos históricos y políticos se lo retoma como referencia para explicar genocidios, nociones de trauma, totalitarismos y abusos a los derechos humanos (2001, p. $15,17,21)$.

En el caso de América Latina, los trabajos sobre la memoria han tenido como principales escenarios las dictaduras del Cono Sur (Argentina, Chile y Uruguay, a las que se fueron sumando otras dictaduras como la de Brasil) durante la década de los setenta. Estos trabajos han colocado el tema de la memoria en discusiones políticas, artísticas y académicas (Basile y Trigo, 2015). En particular, el caso argentino es emblemático por el

\footnotetext{
${ }^{1}$ La concepción clásica sobre la modernidad sostiene una imagen racionalista y secular del mundo. El progreso es una idea central de esta y creer en el progreso implica "amar el futuro", porque esta visión significa dar mayor relevancia a los conflictos del futuro que a los del pasado (Touraine, 1994).
} 
activismo de las Madres de Plaza de Mayo, los juicios a las juntas militares, las comisiones de la verdad, las políticas sobre derechos humanos y la preservación de espacios de memoria que han permitido afianzar el debate en el ámbito público. Esta influencia se observa en contextos como el mexicano, en donde se ha abierto la discusión sobre la memoria como política pública por parte del presidente Andrés Manuel López Obrador, quien ha reconocido la necesidad de buscar "verdad" y "justicia" para las víctimas de la violencia desatada con mayor fuerza a partir del $2006^{2}$ cuando el ejército salió a las calles para combatir a los "cárteles" de la droga. En este sentido, las referencias a los casos sudamericanos por sus políticas sobre la memoria son frecuentes en los "Foros Escucha"3.

Si bien no se puede negar la importancia que ha tenido el Cono Sur en las problemáticas sobre la memoria en América Latina, los escenarios y abordajes no se limitan a los contextos dictatoriales, porque la complejidad y

${ }^{2}$ Medida tomada por el entonces presidente Felipe Calderón Hinojosa, quien había llegado al poder acusado de haber cometido fraude electoral. Hay quienes señalan que la medida de sacar el Ejército a las calles fue una de las vías usadas para legitimar su presidencia.

${ }^{3}$ Foros creados por el equipo de transición del presidente de la República, Andrés Manuel López Obrador, cuyo objetivo es escuchar a las víctimas de la "guerra contra el narcotráfico" que ha dejado miles de desaparecidos en el país desde el 2006 a la fecha. Se pretende generar "verdad" y "justicia" para pacificar el país. Una primera medida fue el decreto para crear una Comisión de la Verdad sobre el caso Ayotzinapa el 3 de diciembre del 2018.

Los foros han mostrado una realidad desoladora sobre desaparecidos en México, pues, según el diario La Jornada, se calcula que hay más de 37 mil personas reportadas como desaparecidas hasta el 2018, cifra que sigue en aumento.

Un aspecto que ha desatado la polémica en el país es que el primero de diciembre, en el marco de la toma de protesta como presidente de México, Andrés Manuel López Obrador propuso un "punto final" para los delitos cometidos por los políticos que le antecedieron. La inconformidad de un importante sector de la población radica en que un factor clave para que existan estas desapariciones y violaciones a los derechos humanos es la impunidad orquestada desde los distintos poderes del Estado desde hace décadas. Por lo que resulta inconcebible que salgan sin responder por el cementerio en que se ha convertido México.

https://lopezobrador.org.mx/temas/foro-escucha/ https://www.jornada.com.mx/2018/06/03/politica/011n1pol 
la diversidad de las sociedades latinoamericanas nos posiciona frente a panoramas dispares provocados por factores económicos, políticos y culturales. De esta forma, hay que recalcar que, desde algunas perspectivas, el conflicto en torno a la memoria

arranca con la conquista, se continúa bajo las distintas variantes del colonialismo, el neocolonialismo, el poscolonialismo y el colonialismo interno, y se reformula en la organización de estados modernos, la invención de imaginarios nacionales y la configuración de identidades siempre en vilo, siempre ambiguas, siempre en disputa (Basile y Trigo, 2015, p. 5).

Otear algunas de las memorias desde la conquista como punto de quiebre nos brinda la posibilidad de "pensar las crisis de la memoria que afligen a tantos países de América Latina desde las últimas décadas del siglo pasado como manifestaciones de un proceso de larga duración a escala mundial". Este enfoque permite estudiar "otras crisis de memoria" y "otras memorias en crisis" (p. 7).

Un abordaje de esas "otras memorias en crisis" lo encontramos en Gloria Anzaldúa ${ }^{4}$, quien a través de su libro Borderlands/La Frontera: The

${ }^{4}$ Gloria Evangelina Anzaldúa nació en 1942 en Raymond ville, Texas. Ella fue la mayor de cuatro hermanos. Su infancia estuvo marcada por el campo debido a que su familia realizaba trabajos temporales en distintos ranchos y ahí los miembros de la familia eran objeto de abusos por parte de los patrones. Desde muy temprana edad desarrolló el gusto por la lectura.

En cuanto a su educación, en 1962 se matriculó en Texas Woman's University, pero después del primer año no pudo cubrir más la colegiatura, así que tuvo que abandonar la escuela y trabajar durante dos años para poder retomar sus estudios en la Pan-American University donde obtuvo la licenciatura en Inglés en 1969. Una vez concluida la universidad se dedicó a dar clases en distintas instituciones. En 1972 comenzó una maestría en Inglés y 
New Mestiza plantea una mirada hacia el pasado chicano ${ }^{5}$ para reivindicar símbolos, tradiciones y lenguas no reconocidas y deslegitimadas por sectores "gringos" 6 en los Estados Unidos de Norteamérica. En este sentido, la autora reflexiona, por medio de los términos "border" y "borderlands", sobre los límites fronterizos y el impacto que han tenido en los chicanos. Para ello, trabaja la frontera entre México y Estados Unidos, en donde a nivel territorial nos encontramos con dos tipos de vallas o muros, el físico y el militar (Belausteguigoitia, 2015). Ese muro representa y ha representado un drama para América Latina, se ha convertido en lo que Anzaldúa llama "una herida abierta" que sangra, en donde se exhibe una clara división entre "otros" y "nosotros". A esta línea física, a este muro lo denomina border: "A border is a dividing line, a narrow strip along a steep edge" 7 . Mientras que borderlands "is a vague and undetermined place created by the emotional

Educación en la Universidad de Austin, Texas, y en 1988 fue aceptada para el doctorado en literatura de la Universidad de Santa Cruz. Fue una de las primeras escritoras chicanas abiertamente lesbiana y reconocida por su activismo político. Murió en 2004 por complicaciones derivadas de la diabetes.

${ }^{5}$ Los chicanos viven en los Estados Unidos y han construido una narrativa en la que retoman elementos de diversas culturas, resaltando las referencias hacia el México prehispánico. El punto de partida del relato de este grupo se remonta a la guerra México-Estados Unidos en 1846 que culminó con la firma del Tratado de Guadalupe-Hidalgo en 1848. En dicho tratado se estipulaba la cesión de más de la mitad del territorio mexicano a los Estados Unidos de Norteamérica. Así, los chicanos se reapropian de ese pasado para construir su narrativa. Su argumento central ha sido la necesidad de luchar contra los abusos y las imposiciones de la sociedad angloamericana. Hay quienes señalan que esa lucha se remonta al siglo XIX, pero recién en la década de los sesenta del siglo XX lograron una agenda que les dio gran visibilidad y se logró que se les reconocieran algunos de los sus derechos.

'La Real Academia Española define "gringo" como "extranjero, especialmente de habla inglesa, y en general hablante de una lengua que no sea la española". Por su parte, Anzaldúa utiliza este término para hacer referencia al estadounidense "blanco", al que ha usado su poder para someter y explotar a ciertos sectores en Estados Unidos.

${ }^{7}$ Las citas del libro Borderlands... no serán traducidas al español porque no se reflejaría la construcción de una narrativa a través del spanglish. La traducción significaría la perdida de esa riqueza lingüística que Anzaldúa refleja en el texto al hacer uso de términos provenientes de distintas lenguas. 
residue of an unnatural boundary. It is in a constant state of transition" (1987, p. 3). En borderlands habitan los "atravesados", las "atravesadas", los queer 8 , los que están más allá de lo "normal".

Esta relación border/borderlands es retomada por Abril Trigo a través de los términos "frontera" y "frontería". La frontera funciona como un límite, un muro entre estados nacionales, es "lo que cierra y delimita, lo que obstruye y construye identidades, lo que define la civilización más acá de la barbarie" y la frontería articula un espacio territorial (más que un límite) en el cual se cruzan e hibridizan las diversas culturas. De esta forma, "la frontera legisla la razón de estado; la frontería es indiferente a la nación; la frontera es marca de Historia, la frontería habilita memorias fragmentarias" (1997, p. $80,81)$.

${ }^{8}$ Palabra que es utilizada para definir lo extraño, lo raro y lo desviado. "Queer" era un término despectivo y hacía referencia a los "anormales". Sin embargo, ha sido reivindicado por los estudios de género y actualmente hay una perspectiva epistemológica que se denomina "teoría queer".

Lo queer cuestiona el binarismo de las identidades sexuales, "tales como, hombre/mujer, heterosexual/homosexual, entre otros". Asimismo, "no sólo es un grupo de teorías o un movimiento contestatario, sino también, un modo de aproximarse a la realidad en un incesante cuestionamiento a todo lo que se entiende como natural o inalterable" (Sierra, 2009, p. 30-31). A nivel de movimiento social lo queer implica "la lucha por el reconocimiento de la alteridad, por la recuperación de otras identidades negadas y expulsadas hacia la exterioridad simbólica pero también económica y social" (Sierra, 2009:38). Anzaldúa recurre a este término para dar cuenta de su condición como lesbiana y defender a quienes no "encajen" con los supuestos sobre sexualidad que se han establecido desde un pensamiento patriarcal. 


\section{Estructura de la Tesis}

Esta Tesis está compuesta por dos capítulos. En el primer capítulo "De la nación a las memorias fronterizas: el caso chicano", trazamos un itinerario que va desde la nación percibida como una entidad homogénea hasta su hibridación capaz de reconocer en su interior la presencia de alteridades y cruces culturales. Por eso se aborda la concepción que tiene Ernest Renan (2010) sobre la nación y cuáles son algunos de los elementos que ésta debe tener para poder ser considerada como tal. Posteriormente, se analizan algunas de las críticas realizadas por autores como Homi Bhabha (2000 y 2002), Eric Hobsbawm (1998), Ernest Gellner (2001) y Benedict Anderson (1993) a la idea de nación y su pretensión de una narrativa homogénea, pues esa concepción ha ocultado y/o negado otros relatos que no se "acomodan" con las versiones hegemónicas que justifican el "origen" de una nación, por lo que esa "legitimidad" será disputada, en ocasiones apropiada o revalorada por distintos sectores sociales como muestra Néstor García Canclini (2009) a través de su estudio sobre las culturas híbridas.

En la segunda parte de este capítulo ("Teorías de la frontera: repensar la memoria y la identidad") se retoman algunas teorías de la frontera para reflexionar sobre la identidad. Este punto nos abre la puerta para abordar las "memorias en conflicto" (punto 1.3) desde las teorías de autores como Tzvetan Todorov (2000), Michael Pollak (2006), Hugo Vezzetti (2002 y 2009) y Enzo Traverso (2007). Este sentido conflictivo de la memoria brinda herramientas para abordar algunas líneas sobre el pasado que trabaja Anzaldúa para cuestionar narrativas que pretenden homogeneizar a los chicanos. Un recurso fundamental en esta tarea es el testimonio, porque a través de él se deconstruyen concepciones hegemonizadas sobre el pasado y se abre la posibilidad de encontrar sentidos poco "comunes" o "demeritados". 
Finalmente, en el punto "Una mirada a la sociedad chicana" se exponen algunos de los derroteros históricos de los chicanos, los problemas para construir su narrativa, las críticas a la asimilación, el uso de términos como "pocho" y "pachuco" para denigrar a los chicanos, el señalamiento constante por no hablar de manera "correcta" el inglés y el pensamiento "machista" dominante en el grupo que relegaba a las mujeres a un segundo plano. En la década de los sesenta, los chicanos salieron a las calles para protestar por las condiciones laborales, económicas y políticas en las que se encontraban. Estas manifestaciones son tomadas como un precedente que pone en la escena pública algunas de las problemáticas del grupo, entre ellas las del feminismo chicano que interpela los presupuestos que los hombres chicanos establecían como parte de su narrativa, en la que se relegaba a las mujeres a un ámbito doméstico.

En el segundo capítulo "Borderlands/La Frontera: The New Mestiza: la apuesta por una 'memoria Nepantla", pasamos desde la perspectiva teórica centrada en la crítica al concepto homogéneo de nación y en la visibilización de los procesos de hibridación (constitutivos de la cultura chicana) hacia el análisis de un caso desatacado como es el libro Borderlands... de Anzaldúa, donde la "memoria Nepantla" se convierte en un principio constructivo de su textualidad. Para ello, luego de describir las perspectivas generales del texto (punto 2.1), se analizan los ejes del spanglish ${ }^{9}$ (punto 2.2) y los símbolos femeninos (punto 2.3) como la Virgen de Guadalupe, la Malinche y la Llorona, en tanto detonantes para construir una "memoria Nepantla" y una "Nueva Mestiza" (punto 2.4).

La cuestión sobre el spanglish es central porque Anzaldúa considera que el recurrir a frases o palabras en español dentro de una sociedad en la que se habla principalmente el inglés ha sido motivo de coerción y

${ }^{9} \mathrm{El}$ spanglish surge de la hibridación entre el español y el inglés principalmente. Esta lengua tiene diversas manifestaciones, por lo que no se puede homogeneizar, ya que no es lo mismo el spanglish chicano que el puertorriqueño, llamado "nuyorican" (término que surge de una combinación entre el origen: Puerto Rico, y el espacio en el que la mayoría de los puertorriqueños se establecen: Nueva York). 
discriminación, por lo que es relevante reivindicar esta lengua, exigir su reconocimiento, pues mientras se siga viendo como una lengua bastarda, el rechazo a los chicanos persistirá.

Asimismo, los principales símbolos femeninos que Anzaldúa retoma son: la Malinche, la Virgen de Guadalupe y la Llorona. Estos son deconstruidos para resignificar el lugar de las mujeres en la sociedad chicana. En esta tarea, la autora se remonta a tradiciones prehispánicas que muestran la pérdida de equilibrio entre lo femenino y lo masculino, contribuyendo a una imagen negativa sobre la mujer que terminó siendo reforzada por la narrativa patriarcal española. Sin embargo, estos símbolos representan a mujeres fuertes y con un papel protagónico en la historia del grupo.

También se propone el análisis de la "memoria Nepantla"10, una de esas "otras memorias" que permite articular los cruces entre distintas narrativas, porque a través de ésta se rescatan aspectos lingüísticos, políticos, económicos y culturales que son incluyentes de las alteridades, criticando las perspectivas teóricas que pretenden ser esencialistas respecto a los supuestos que han dado origen a determinadas visiones sobre el pasado.

\footnotetext{
${ }^{10} \mathrm{El}$ término "Nepantla" hace referencia a "estar en medio". Miguel Pastrana Flores señala que este concepto fue enunciado por un indígena a fray Diego Durán para explicar su extraña actitud religiosa y presenta el siguiente testimonio:
}

\footnotetext{
-Padre, no te espantes, pues todavía estamos nepantla, y como entendiese lo que quería decir por aquel vocablo y metáfora, que quiere decir "estar en medio", torné a insistir me dijese qué medio era aquel en que estaban. Me dijo que, como no estaban aún bien arraigados en la fe, que no me espantase; de manera que aún estaban neutros, que ni bien acudían a la una ley, ni a la otra, o por mejor decir, que creían en Dios y que juntamente acudían a sus costumbres antiguas y ritos del demonio, y esto quiso decir aquel en su abominable excusa de que aún permanecían "en medio y eran neutros" (2009, p. 275).
} 
Configuración de una "memoria Nepantla" en Borderlands...

Maestría en Historia y Memoria

Universidad Nacional de la Plata

Finalmente, esta "memoria Nepantla" se articula con la "Nueva Mestiza" propuesta por Anzaldúa y hace referencia a esa posibilidad de transitar de una cultura a otra. La tarea primordial de la "Nueva Mestiza" radica en cuestionar la herencia recibida y reconocer cuáles son los legados que contribuyen a generar una sociedad abierta a las diferencias y a los "otros".

Desde los debates y las perspectivas teóricas elaboradas en América Latina a partir de las últimas dictaduras en el Cono Sur, esta Tesis procura explorar otros contextos latinoamericanos en los cuales la memoria ha jugado y sigue jugando un papel fundamental en la demanda de derechos, como es el caso de la cultura chicana. 


\section{CAPÍTULO I}

\section{DE LA NACIÓN A LAS “MEMORIAS FRONTERIZAS”: EL CASO CHICANO}

El abordaje sobre el pasado, en el contexto de los estudios sobre la memoria, tiene principalmente dos escenarios: el de la memoria y el de la historia, cada uno con sus particulares perspectivas teóricas. Estos campos (historia y memoria) no están separadas y tampoco son necesariamente antagónicos, ya que ahora la disciplina histórica (en algunas de sus vertientes) puede recurrir a los testimonios producidos por las memorias individuales o las colectivas para tomarlas como parte de sus investigaciones (Traverso, 2007). A su vez las memorias sociales hacen uso de las investigaciones históricas, ya sea para reafirmar lo que se cree en torno a un determinado suceso o para impugnar y cuestionar la versión histórica que se pretende erigir.

En este capítulo se abordan distintas perspectivas sobre la memoria para enfocarnos posteriormente en cómo la memoria fronteriza surge desde un "paradigma otro", utilizando los términos de Walter Mignolo (2003, p. 20), donde lo importante no es disputar la hegemonía de un paradigma al estilo tradicional del pensamiento occidental que intenta imponerse sobre otros pensamientos. Al menos ésa ha sido la narrativa sobre los paradigmas desde que fue instalada esta noción por parte de Thomas Kuhn (2013): se trata de un concepto que se originó alrededor de las teorías científicas, colándose en el pensamiento de las ciencias sociales. Para Kuhn cada una de las teorías científicas que explican el mundo es distinta a la otra, no hay un decurso progresivo en las teorías, sino un "rompimiento" con la previa que termina instalando una nueva forma de ver el mundo, una explicación que va modificando los distintos ámbitos de la sociedad, es decir, un nuevo paradigma. 
Contrario al planteo de Kuhn, para Mignolo el "paradigma otro" surge a raíz de la necesidad de contar otra historia, un relato en el que los "ocultados" por el pensamiento dominante puedan alzar la voz. De esta forma "el paradigma otro es, en última instancia, el pensamiento crítico y utopístico que se articula en todos aquellos lugares en los cuales la expansión imperio/colonial le negó la posibilidad de razón, de pensamiento y de pensar el futuro" (2003, p. 20). No sólo se trata de cuestionar los paradigmas que han dominado el pensamiento occidental, sino de evidenciar cómo la producción de éstos prolongaba las circunstancias de opresión de grupos considerados "vulnerables" por sus condiciones económicas, raciales y políticas, entre otras.

De esta forma, se pretende abordar algunas teorías que analizan cómo ha sido posible alzar la voz y construir un "paradigma otro" para los excluidos de las narrativas dominantes, y cómo han logrado rescatar, reivindicar, afianzar o reconstruir una memoria social que les permita resignificar su relación con el pasado y el presente. Uno de esos grupos es el de los chicanos, quienes tienen una historia de lucha afincada en el reconocimiento y la construcción de un relato propio. Este grupo forma parte de esos sectores marginados que han sido relegados dentro de una narrativa dominante en la sociedad estadounidense blanca. De ahí que textos como el de Anzaldúa, Bordelands/La Frontera: The New Mestiza, arremetan contra este relegamiento y reivindiquen una identidad en la que no haya sólo una forma "correcta" de ser chicano. Se trata de una visión sobre la identidad en la que se "eliminan" las políticas de normar lo que es, precisamente, una "auténtica" identidad. Por tal razón, para llegar a esta apuesta teórica que realiza la autora, es necesario abordar algunos aspectos sobre la nación en donde se pretende estipular qué es la identidad y, con base en esto, excluir a "otros" por no ser "nosotros". 


\subsection{De la nación a las culturas híbridas}

La mayoría de las narrativas nacionales establecen una homogeneidad discursiva con carácter sagrado que delimita un "adentro" y un "afuera", un "nosotros" y un "ellos", olvidando que "la nación es una abstracción, una alegoría, un mito, que no corresponde a una realidad constante y precisa, científicamente determinable" (Mariátegui, 2000, p. 67). Estas "ficciones fundacionales" se convierten en el "respaldo" de las tradiciones nacionales para justificar la afiliación, pero también para desaprobar, desplazar y excluir. Sin embargo, cuando se interpelan estas narrativas se "empieza a ver que la nación es construida a través de muchas formas de identificación contingentes, arbitrarias e indeterminadas" (Bhabha, 2000, p. 228), por lo que su carácter "sagrado" se desdibuja.

De esta forma, la concepción de que la nación "era una unidad cultural homogénea, caracterizada por distintas costumbres, prácticas sociales, valores morales, modos de relaciones interpersonales, lenguaje, rituales, mitos, rasgos de temperamento, un sistema común de significados [...]"ha sido fuertemente cuestionada, pero no olvidemos que "los autores nacionalistas a menudo justificaron el derecho de cada nación [...] de preservar su identidad sobre la base de que ésa era la única manera de contribuir al enriquecimiento y al completo desarrollo de la humanidad" (Parekh, 2000, p. 99, 100). Sin embargo, esa pretensión de homogeneidad es una quimera, pues como muestra el trabajo de Néstor García Canclini (2009), las naciones son heterogéneas. 


\section{Una mirada sobre el origen de la nación en Ernest Renan}

Ernest Renan en un artículo “¿Qué es una nación?”[1882] analiza cuáles son los aspectos que originan a una nación con la finalidad de descartar los elementos accidentales y, así, encontrar lo esencial en la misma. De esta forma, el olvido es una de las principales cuestiones que resalta, ya que en los inicios de una nación la violencia está presente, por lo que, para poder construirla es fundamental el olvido de los conflictos y divergencias iniciales que perturban la configuración de la unidad nacional. Sin embargo, a pesar de apelar al olvido sobre determinados actos, hay otros acontecimientos violentos que no deben ser olvidados sino ensalzados por la narrativa que constituye a una nación. Pero ¿qué actos violentos sí deben ser recordados? y ¿cómo deben ser rememorados en ese relato? Aquí aparece un primer punto de tensión en la construcción de una nación, porque si deben ser recordados hechos violentos para rememorar las penurias que nos llevan a estar juntos ¿quién estipula cuáles serán los acontecimientos que permitan reforzar la unidad dentro de una nación? Sobre este punto, Renan menciona que los estudios históricos suelen ser un peligro para la justificación de una nación debido a que evidencian la violencia que está en los cimientos y cuestionan aspectos considerados esenciales para la misma. Por lo tanto, la esencia de la nación radica en compartir muchos elementos en común, pero también en haber olvidado otros $(2010$, p. 26$)$.

Para este autor, hay cuatro aspectos que no son esenciales dentro de la construcción de una nación: las consideraciones etnográficas, la lengua, el territorio y la religión, es decir, ninguno de estos puntos es relevante a la hora del nacimiento de una nación. En este sentido, en el origen etnográfico no puede sustentarse la idea de nación por la diversidad de pueblos que la conforman, por lo que "no hay raza pura", y por lo tanto "hacer depender las políticas del análisis etnográfico es entregarse a una quimera" (p. 29). También en una nación se unen distintos pueblos, muchas veces con 
lenguas diferentes, en consecuencia no existe un fundamento para legitimar a una determinada lengua sobre otra, así que ésta tampoco representa un pilar fuerte para decir que ahí radica lo que es una nación. Lo mismo sucede con el territorio, un país comienza ocupando cierto espacio y después, derivado de ocupaciones o de guerras, expande o pierde parte de su territorio. Por último, la religión completa esta lista de las cuestiones accidentales que forman parte de una nación, ya que se puede ser católico, protestante, o de cualquier otra religión, y seguir perteneciendo a una nación. Si ninguno de los puntos anteriores es relevante, entonces ¿en qué se fundamenta la idea de nación? Renan argumenta que la nación se asienta en un principio espiritual, en una voluntad de permanecer unidos a pesar de las vicisitudes del pasado (p. 35), ya que las desavenencias serán olvidadas. Esa unidad será alimentada por lo que llama "memorias de una nación" (hay que recordar el peligro que implican los estudios históricos para la justificación de nación), pues a través de ciertos relatos se impondrá la necesidad y obligación de trabajar juntos para que la nación permanezca.

La nación moderna, pensada por Renan, fue producto de un momento en el que se buscaba ir más allá de los estados monárquicos que antes habían dominado en algunas latitudes. Como forma de organización política resultó ser un elemento novedoso al partir de un fundamento humano y no teocrático, ni de otra índole. Sin embargo, la idea de nación se articula en una especie de homogeneidad sostenida en un principio espiritual, pero ¿a qué remite este principio? Se refiere al "consenso" que une a los pueblos, sustentado en sus recuerdos, en sus héroes, en sus glorias que implican un gran sacrificio y que interpelan a una nación sobre si está dispuesta a seguir sacrificando y glorificando para seguir siendo. Esta visión tolera pugnas con otras naciones, pero pasa por alto la idea de conflictividad dentro de la nación porque se supone que las disputas fueron enfrentadas en el nacimiento de ésta, no en su presente, ni con su actual sociedad. Por otra parte, el principio espiritual implica que los "pueblos" que componen una nación tengan una adhesión "voluntaria". Pero la nación en la actualidad, y probablemente antes también, no es siempre una elección. No todos los 
grupos que la conforman se pueden identificar con esas glorias o sacrificios del pasado que la justifican. Si bien el "olvido" puede invocarse a través de las narrativas dominantes, nunca se puede controlar completamente en la sociedad, es decir, así como hay una memoria hegemónica de la nación que "difunde" los relatos del origen nacional, también se crean en contraposición relatos que cuestionan aquellas narrativas.

Tampoco puede obviarse que la lengua, la religión, el componente etnográfico y el territorio no debieran ser los ejes sobre los cuales se articule una nación, en muchos casos hay una religión que se declara oficial, una lengua oficial, una "raza" ideal y una referencia dogmática al territorio, es decir, hay una defensa de la nación como si esos elementos fueran centrales y perennes en su constitución.

Por lo tanto, diversos grupos sociales inmersos en una nación han puesto en duda desde distintos frentes esa supuesta homogeneidad y ese principio de unidad que en teoría la caracterizan; han cuestionado ese pasado unívoco y han intentado rescatar o exhibir las memorias de sus antepasados, aquellos que no tuvieron cabida en el pasado "glorioso".

Todos esos principios, que Renan consideraba como aspectos no trascendentales en una nación, son los que fracturan precisamente el principio espiritual que deben sustentarla y han hecho que en la actualidad se cuestione la integridad de la misma.

\section{Nación y nacionalismo: una pretensión de homogeneidad narrativa}

La nación moderna ha suscitado una serie de reflexiones sobre su origen y los aspectos que se consideran fundamentales para ésta. Sin embargo, intentar fijar su inicio y los elementos que la sustentan no es tarea fácil, aunque como señala Hobsbawm "la característica básica de la nación 
moderna y de todo lo relacionado con ella es su modernidad" (1998, p. 23). Es hasta después de la Primera Guerra Mundial, como sostiene Benedict Anderson, que la misma comenzó a ser "la norma internacional legítima" (1993, p. 161). Desde un punto de vista histórico, asumir que la nación no siempre ha estado, o no ha sido como la conocemos hoy en día, permite comprender que no se trata de un constructo político-social perenne, y por lo tanto hay que abordar los supuestos que la conforman para analizarla, cuestionarla y deconstruirla.

Uno de los aspectos a través del cual la nación ha sido desarmada es el de su narrativa fundacional, ya que ésta plantea una homogeneidad discursiva en la que no existen conflictos o donde la justificación de una nación termina por eliminar/ocultar diferencias y establecer un relato que defiende la "unidad" de la nación. Esa "ausencia" de conflictos internos en las narraciones nacionales ha sido interpelada de forma severa a partir de la segunda mitad del siglo XX. Las disputas poscoloniales ocupan un lugar privilegiado en el cuestionamiento de esa homogeneidad nacional (Franz Fanon, Edward Said, Homi Bhabha, Gloria Anzaldúa, entre otros), ya que ponen en evidencia las profundas desigualdades que existen entre "naciones, razas, comunidades y pueblos" (Bhabha, 2002, p. 212) y cuestionan los discursos que legitiman esas desventajas. Aunque para autores como Walter Mignolo (2007), en lo referente a América Latina, la nación ha sido un lugar de conflictos identitarios desde los movimientos independentistas, por lo tanto, él no sostiene la perspectiva poscolonial sino la "decolonial"11, desde la cual rescata las disputas que se han dado durante

\footnotetext{
${ }^{11}$ Los estudios decoloniales retoman los procesos descolonizadores que ha habido en el mundo. En este sentido, "la primera descolonialización (iniciada en el siglo XIX por las colonias españolas y seguida en el XX por las colonias inglesas y francesas) fue incompleta, ya que se limitó a la independencia jurídico-política de las periferias". Pero, "la segunda descolonización", la que es considerada más importante, y es en la que se utiliza propiamente el término "decolonial", es la que propone revisar a fondo "las múltiples relaciones raciales, étnicas, sexuales, epistémicas, económicas y de género que la primera descolonialización dejó intactas" (Castro-Gómez y Grosfoguel, 2007, p. 17). Para Santiago Castro-Gómez y Ramón Grosfoguel (2007), el paradigma de la decolonialidad tiende a
} 
la Colonia a partir de la llegada de los españoles. En esta línea se encuentran también autores como Martin Lienhard (2003), quien muestra cómo en la construcción de las naciones latinoamericanas los mestizos tienen un papel primordial, en contra de las versiones que sólo ensalzan al criollo. Ante este panorama, autores como Homi Bhabha plantean la necesidad de exhibir que hay otras narrativas que disputan y cuestionan la pretendida homogeneidad de la nación, por lo que es fundamental establecer "otro tiempo de escritura que pueda inscribir las intersecciones ambivalentes y quiasmáticas de tiempo y lugar que constituyen la experiencia 'moderna' problemática de la nación occidental” (2002, p. 177).

Es necesario entonces abordar los términos de nación y nacionalismo, sin pretender la univocidad, sino buscando conocer varias perspectivas, que han sido aportadas por algunos teóricos. Como adelantamos, Ernest Renan, en uno de sus intentos por definir la nación, argumenta que ésta es un principio espiritual, un alma nacional que está conformada por una memoria inscrita en el pasado, un legado común, y un consentimiento dado en el presente que reafirma el deseo de vivir juntos y de continuar con aquella herencia (2010).

Sin embargo, esa voluntad de asumir un pasado y consentir lo que se vive en el presente a partir de esos recuerdos ha sido cuestionada, pues ¿quiénes son los que participan en el consenso y estipulan lo que se va a recordar y bajo qué premisas se han desdeñado otros recuerdos? Lo anterior obliga a replantear la necesidad de establecer el acuerdo desde un enfoque en el que se asuma la diversidad que constituye a las naciones, por lo tanto la voluntad presente se fundamentaría en el reconocimiento de la diferencia.

Por su parte Hobsbawm menciona la complejidad de dar una definición de nación, pues en sus investigaciones detectó cómo el término, con esas condiciones objetivas que buscaban algunos autores -entre ellos identifica a Renan-, no se adapta siempre a lo que se supone debe ser una prolongado las condiciones de profunda desigualdad en América Latina. 
nación. De ahí que prefiera hacer un estudio histórico sobre lo que se ha entendido como nación y cómo ha tenido un uso distinto en diversos momentos. Una de las certezas que sí plantea el autor respecto a la nación es que no considera a ésta "como una entidad primaria ni invariable" (1998, p. 18). A su vez, Benedict Anderson la define de la siguiente manera: "una comunidad política imaginada como inherentemente limitada y soberana". El autor sostiene que se trata de una "comunidad imaginada" porque los miembros de una nación jamás se conocerán, pero a pesar de esto, y tal vez al estilo de Renan, vive en ellos una comunión. De ahí que Anderson hable de un "tiempo homogéneo vacío [...] donde la simultaneidad es, por decirlo así, transversa, de tiempo cruzado, no marcado por la prefiguración y la realización, sino por la coincidencia temporal, y medida por el reloj y el calendario" (1993, p. 23, 46). Esta reflexión de Anderson lleva a preguntarse sobre los aspectos que hacen posible esa simultaneidad, esa comunidad imaginada y ahí es donde aparece uno de los elementos que ha hecho posible a la nación: el nacionalismo.

Hobsbawm entiende que el nacionalismo exige a cada ciudadano un deber político con su nación, deber que está por encima de todos los demás asuntos públicos. En una línea similar a Ernest Gellner (2001), sostiene la idea de que el nacionalismo da origen a la nación y no al revés. Para ambos autores el nacionalismo parte de una base dudosa, es decir, se fuerzan varios elementos constitutivos de una nación a fin de que lo que se estipula pueda darse por sentado. De esta forma, Hobsbawm expone que "el nacionalismo requiere creer demasiado en lo que es evidente que no es como se pretende" (1998, p. 20).

En la construcción de los estados-nación, tener una narrativa fundacional se considera uno de los aspectos más relevantes, pues es lo que permite articular, hacia el interior, la pertenencia a un relato común homogeneizante y hacia el exterior diferenciarse de las otras naciones. Sin embargo, ese mismo discurso genera los conflictos tanto dentro como fuera de una nación, en palabras de Jacques Derrida, estamos ante un 
"fármacon". Este autor en "La farmacia de Platón" (1997) realiza un análisis del término griego "fármacon", en su estudio indica que esta palabra tiene dos acepciones, por un lado funciona como "remedio" y por el otro como "veneno". Si bien Derrida describe distintos usos del fármacon, hay uno que, al ser trasladado al terreno de la narrativa nacional, contribuye a la comprensión del conflicto suscitado ante una escritura fundacional que se pretende homogénea. Se trata del fármacon en el terreno de la escritura, pues por un lado a ésta se le considera la solución, pero por otro lado esa escritura omite o invisibiliza aquello que no queda plasmado en lo escrito. "EI fármacon de la escritura era bueno para la hipomnesis (re-memoración, recolección, consignación) y no para la mneme (memoria viva y conocimiento) [...]" (p. 135). Así todo relato fundacional rememora eventos y olvida otros.

Precisamente es esa dicotomía la que lleva a Homi Bhabha a pensar su condición de sujeto poscolonial y considerar que el presente está atravesado por migraciones, diásporas y desplazamientos provocados por conflictos territoriales, políticos y económicos principalmente. En este sentido, por esa condición de migrante y ser partícipe de la experiencia poscolonial, Bhabha ocupa lo que denomina un espacio liminar, una borderlands (Anzaldúa, 1987), un in-between que lo llevó a cuestionar visiones homogéneas y horizontales de la nación, observando la heterogeneidad y la verticalidad con la que en realidad está constituida la misma. Fue desde el interior de lo que se considera una nación sostenida en una narrativa común donde terminaron desbordándose los sentidos y evidenciando la diversidad que entraña realmente ésta. Bhabha reconoce la existencia de un tiempo "doble y escindido" de la representación nacional, que cuestiona la visión homogénea y horizontal asociada con la comunidad imaginada de la nación. En una narrativa idealizada sobre la nación, se suele hablar de "pueblos" como entes históricos que terminan por adherirse voluntaria o violentamente a la identidad nacional, sin embargo, los pueblos no forman comunidades fijas y contemplativas de lo que se supone les debería representar, sino que "son también una compleja estrategia retórica 
de referencia social; su reclamo de representatividad provoca una crisis dentro del proceso de significación e interpelación discursiva". En este sentido, se acepta que no puede haber una narrativa legítima en nombre del "pueblo", porque supone una representación reduccionista, en cambio se tendría que hablar de "pueblos" para hacer visibles los conflictos que muchas veces tienen entre sí. Entonces debemos asumir que la nación se vuelve un espacio "liminar" que está internamente marcado por los discursos de minorías, por autoridades antagónicas y tensas localizaciones de la diferencia cultural. Por lo tanto, "la figura liminar del espacio-nación aseguraría que ninguna ideología política podría reclamar para sí la autoridad transcendente o metafísica". Hay una rebeldía dentro de ese espacio narrativo no sólo para disputar el lugar de dominador, sino también para exhibir la absurda pretensión de necesidad y exclusividad que se le atribuye al relato fundacional de una nación. Bhabha destaca la presencia de "contranarrativas" que continuamente borran las fronteras totalizantes de la nación y alteran sus identidades esencialistas (2000, p.182, 184, 185).

Menciona, además, la importancia de la diferencia cultural y no de una simple pluralidad, pues la diferencia cultural entraña no sólo lo diverso dentro de la narrativa, sino también un nuevo punto de vista -el de las minorías- desde el cual mirar la forja de significados. "El objetivo de la diferencia cultural es rearticular la suma de conocimiento desde la perspectiva de la posición significante de la minoría que resiste la totalización, la repetición que no retornará como lo mismo" (2002, p. 199). En la narrativa nacionalista se puede identificar la idea de un "nosotros" delimitado y rígido frente a un "ellos" que también es asumido como homogéneo:

¿Y quiénes son «ellos»? Obviamente, y virtualmente por definición, los que «no son nosotros», los extraños que son enemigos por su propia condición de extraños. Extraños presentes, extraños pasados, incluso extraños puramente 
hipotéticos como en Polonia, donde, pese a la total ausencia de judíos, sigue utilizándose el antisemitismo para explicar los males del país. Si no existieran los extranjeros con sus viles trucos, habría que inventarlos (Hobsbawm, 1998, p. 184).

"Ellos" representan a los grupos que dentro de una nación son excluidos y/o rechazados bajo argumentos culturales y raciales, principalmente. Pero esa exclusión no conduce a la pasividad, resignación o sacrificio. Los "otros", dentro de una nación, resisten y confrontan la narrativa homogeneizadora.

\section{Las culturas híbridas que interpelan la homogeneidad de la nación}

Cuando se asume que una nación es heterogénea, y que la mayoría de las veces esa diversidad no genera un vínculo pleno entre quienes la conforman, se deben analizar, entonces, los procesos mediante los cuales esas heterogeneidades conviven, adoptan y adaptan prácticas que, desde cierto punto de vista, "pertenecen a otros". Para hablar de esa heterogeneidad, se ha retomado el estudio sobre culturas realizado por Néstor García Canclini (2009) ya que es un análisis enfocado en algunas de las naciones latinoamericanas y que trasciende, de cierta forma, los términos utilizados tradicionalmente para explicar los procesos de interacción cultural, como son "mestizaje" y "sincretismo".

El término "mestizaje" ha sido utilizado para hacer referencia a las mezclas raciales. En el caso de México, la narrativa sobre el mestizaje dominó durante casi todo el siglo XX. Este relato respondió a la necesidad de generar un proyecto nacional después del conflicto revolucionario de 1910. De ahí la noción de "raza cósmica" de José Vasconcelos (1948), una 
raza perfecta por ser producto del mestizaje entre los distintos pueblos que conformaban el país. Sin embargo, en las últimas décadas, se ha desacreditado el discurso sobre el mestizaje que explica la conformación de la nación mexicana. Este descrédito viene, por un lado, porque se asumió que con esa narrativa México anclaba su homogeneidad como nación. Por otro lado varios autores han señalado que el mestizaje sólo se refiere al cruce entre indígenas y españoles, ocultándose la presencia de comunidades de chinos, africanos, japoneses, entre otras (Carroll, 1995; Navarrete, 2004).

Por su parte, el término "sincretismo" ha sido utilizado en el contexto latinoamericano para dar cuenta de los procesos de transformación religiosa que se dieron a partir de la llegada de los españoles en el siglo XV (aunque también se habla de sincretismo cultural, político, filosófico). El sincretismo supone una reinterpretación simbólica y ritual de determinadas prácticas y creencias, no una sustitución. Para Jordi Gussinyer (1996), este fenómeno religioso describe una actitud consciente de ciertos grupos sociales que asumen "otras" prácticas religiosas para evitar sufrimientos y poder seguir adorando a sus dioses. En este sentido, "se dice que los indios enterraban a los ídolos tras los altares o bajo el basamento de las cruces para seguir adorándolos mientras los misioneros creían que rendían culto a la nueva religión"12 (Carrasco, 1975, p. 201).

De esta forma, en el libro Culturas híbridas, García Canclini plantea una cuestión central sobre las dinámicas sociales: ¿cómo conviven grupos que parecen ser "antagónicos" desde ciertas visiones puristas y maniqueas? Al respecto, el autor sostiene que las relaciones sociales no son estáticas ni rígidas, sino que entran en cruces que él denomina hibridaciones, las cuales consisten en "procesos socioculturales en los que estructuras o prácticas

\footnotetext{
${ }^{12}$ Por nueva religión se entendía al catolicismo español. Esta forma de actuar de los indígenas ante símbolos y rituales católicos provocó un sincretismo, pues se pueden rastrear elementos indígenas en muchas de las imágenes y edificios que son producto de la colonia.
} 
discretas, que existían en forma separada, se combinan para generar nuevas estructuras, objetos y prácticas" (García Canclini, 2009, p. 14). Pero ¿cómo se logra que esas estructuras o prácticas se combinen? ¿cómo se da el cruce? Por varias razones, no siempre bien planeadas: por motivos migratorios, de intercambio económico, entre otras.

Asimismo, en el texto desarticula la homogeneidad con la que los discursos nacionales legitiman su hegemonía cultural y se pretenden poseedores de una identidad verdadera. No hay identidades "puras" o "auténticas", por lo que no existe la posibilidad de hablar en nombre de una identidad unívoca, y de hecho resulta un riesgo pretender que la identidad sea estática, pues eso hace que ciertos grupos asuman una posición cerrada y aislada frente a otros. De ahí que se proponga abordar la hibridación desde la heterogeneidad, porque sólo desde ese lugar es que se podrán comprender las transformaciones culturales que se dan en el seno de las sociedades.

El término "híbrido" irrumpió en el escenario latinoamericano con una perspectiva innovadora para analizar los complejos procesos culturales que se dan en esta parte del continente. A través de este concepto García Canclini desarticula las dicotomías entre lo tradicional y lo moderno, lo popular y lo culto, oposiciones sostenidas por disciplinas que marcaban las diferencias entre lo "culto" y lo "popular"13. Sin embargo, en América Latina son muchos los ejemplos en donde coexisten lo culto y lo masivo, así como lo tradicional y lo moderno, por lo que, el autor desarma la oposición entre las culturas "premodernas" y el mercado que se maneja según las reglas de la modernidad, pues ambas se entrecruzan y "conviven".

${ }_{13}$ Desde el análisis de García Canclini, las ciencias sociales han contribuido en la construcción de estas dicotomías, pues, por ejemplo, el antropólogo y el sociólogo registran formas de vida pero con "escalas de observación" distintas, por lo tanto construyen una visión parcial de sus objetos de estudios. 


\section{Tradicionalismo versus modernización}

En Apocalípticos e integrados, Umberto Eco cuenta cómo los cambios en el seno de las sociedades suelen representar, para algunos, un hecho traumático. Por ejemplo, la aparición de la escritura significaba el fin de la memoria como tal, aunque ese sentido de catástrofe respecto a la memoria no nos asusta más por el hecho de que hemos sido testigos de las ventajas que ha representado la escritura. Ese temor excesivo a los cambios representa la actitud de los "apocalípticos", quienes no sólo imaginan el fin de un orden, sino la degradación de una sociedad. Su contraparte la encontramos en los "integrados", quienes no ven ningún peligro ante lo que viene y celebran esas transformaciones sin ningún tipo de crítica (2009, p. 51, 66). Este estudio de Eco brinda algunas claves para comprender la pugna que plantea García Canclini entre tradicionalistas y modernistas en el contexto latinoamericano.

En América Latina se ha registrado un intenso debate sobre las condiciones que originaron algunas de las naciones latinoamericanas. También se ha discutido si éstas son modernas al estilo europeo o si aún no han alcanzado la "utopía moderna". Dentro de este debate, se encuentran autores que defienden el surgimiento de un pensamiento moderno en América Latina, tal es el caso de Aníbal Quijano (1988, p. 13), al sostener que esta zona geográfica no fue pasiva y simple receptora de los cambios que se estaban generando en Europa. Si bien estas transformaciones fueron provocadas por la llegada de los europeos al continente americano, no sólo esta parte del mundo sufrió cambios con su arribo, pues también a los europeos se les removieron los presupuestos sobre el mundo que hasta ese momento concebían.

Asimismo, tampoco comparte la afirmación de que las ideas ilustradas son simplemente exportadas desde Europa a América Latina, y aquí son adoptadas y adaptadas por intelectuales latinoamericanos, ya que existen 
evidencias que demuestran que la modernidad se daba en Europa y también en América Latina ${ }^{14}$. Sin embargo, reconoce que existe una paradoja en el contexto latinoamericano respecto a esas ideas de modernidad, porque en Europa se trató de un proceso, en cierto sentido, "homogéneo" al implicar los ámbitos intelectuales, políticos y sociales. Mientras que en América Latina se gestó a nivel intelectual y político, pero no se trató de un proceso que permeara en todos los ámbitos sociales.

Para García Canclini, la permanencia de algunos pensamientos y costumbres en América Latina puede ser visto "como resultado del desigual acceso a los bienes de la modernidad" (1997, p. 112), pero también se debe reconocer que en otros casos se trata de hibridaciones con resultados productivos. Esta idea de hibridación cuestiona esa noción de pasividad e imposición con la que se han concebido algunos procesos culturales en América Latina. Los sectores considerados marginados o relegados de la hegemonía también han generado estrategias que les permiten coexistir y apropiarse de otras manifestaciones sociales. En este sentido, la historia reciente (última mitad del siglo $\mathrm{XX}$ ) hace referencia al relato de cómo las élites y los sectores populares han encontrado la forma de "hibridar lo moderno deseado" y preservar, a través de esa hibridación, lo tradicional que se quiere seguir conservando.

Al igual que Quijano, García Canclini marca una diferencia entre lo que es propiamente el proyecto moderno y lo que implica el proceso de modernización en América Latina. Sin embargo, mientras que para Quijano la modernización arrancó después de la Segunda Guerra Mundial, lo que

\footnotetext{
${ }^{14}$ Cuando Humboldt viene a América, no oculta su sorpresa de encontrar que los círculos de intelectuales y de estudiosos americanos, en cada uno de los principales centros que él visita, conocían lo mismo y estudiaban lo mismo que sus contrapartes europeos, no solamente porque leían lo mismo sino, ante todo, porque se interesaban por los mismos problemas, porque se hacían las mismas cuestiones y procuraban investigarlas con idéntico apasionado afán, aunque bajo condiciones menos propicias. Y que, en fin, el espíritu de la modernidad y sus promesas y necesidades estaban en desarrollo por igual en América que en Europa (Quijano, 1998, p. 13-14).
} 
implicó que perdiera su anclaje con las promesas de la modernidad y directamente se abrieran las puertas al capital, sin que se hubiesen establecido mecanismos democráticos que erradicaran prácticas autoritarias para preservar el poder (1988, p. 18); García Canclini aborda cómo se ha dado esa modernización en connivencia con sectores tradicionalistas, es decir, no asume un discurso de homogeneidad respecto al proceso de modernización porque advierte que en la complejidad latinoamericana no hay un patrón de inclusión/exclusión tajante entre las élites sociales y los sectores "desprotegidos".

De esta forma, se puede identificar que entre los tradicionalistas y los modernizadores existió una pugna que parecía irreconciliable, según García Canclini, cuando ambas posturas pretendieron generar objetos puros. Los tradicionalistas postularon culturas nacionales "auténticas", alejadas de los embates de la industrialización y de las amenazas extranjeras. Los modernizadores concibieron la posibilidad de generar conocimiento autónomo, sin restricciones de ningún tipo. Así, mientras unos abogaban por la "conservación" de las tradiciones y se alarmaban por las transformaciones provocadas por la modernización, los modernizadores valoraban de manera positiva los cambios que se generaban con la entrada de "novedades". Este conflicto se agravaba en la medida en que los tradicionalistas veían amenazado lo que consideraban unas tradiciones legítimas, pues para éstos el conjunto de bienes y prácticas que "nos identifican como nación o como pueblo" se asumen como si fueran lo más sagrado, algo que representa el pasado y que, por lo tanto, justifica el presente. En términos de García Canclini, ese pasado "es apreciado como un don", por lo que no puede ser cuestionado, al contrario, se tiene que preservar y transmitir (2009, p. 17, 150). Para la cultura tradicionalista, en la medida en que se tenía claro cuál es el supuesto pasado que sustenta la identidad, era evidente quiénes representaban una amenaza y posible traición a la herencia sagrada, al no colaborar en la conservación y la trasmisión de la misma. En este sentido, el rechazo hacia los modernizadores iba mucho más allá del simple hecho de representar la "novedad". 
Esta paradoja sobre los desacomodos de la modernidad en América Latina, mencionada por Quijano, aparece también en García Canclini al sostener que algunas élites, en principio, intentaron asumirse modernas, excluyendo a las culturas indígenas ( $p .71$ ), sin embargo, advierte también que no se puede homogeneizar e indicar que todas las élites responden a patrones modernistas. Pero, una vez entrando al siglo XX, se observa un nuevo tipo de modernismo cultural, que se preocupa ahora por los problemas sociales de sus países y recupera elementos "tradicionales" y "originales" de cada uno de los países, como fue el indigenismo ${ }^{15}$ en México, que es resaltado en la corriente muralista posterior a la Revolución Mexicana de 1910.

La modernización, entendida -según Quijano- como la instalación del modelo económico capitalista, garantiza (de cierta manera) el acceso democrático a los bienes de consumo, pues en un mercado que necesita expandirse, los privilegios de algunos, en cuanto al acceso de "exclusivos productos culturales, pierde relevancia" (García Canclini, 2009, p. 85). Ya no se trata de ver quién tiene la "cultura" que se necesita para acceder a determinados productos considerados de "alta" (arte) o "baja" (artesanías) cultura, sino quién tiene el recurso para hacerse de una millonaria pieza de obra de arte. Evidentemente bajo esa lógica tampoco se garantiza que todos puedan tener acceso. Si bien regularmente las élites cuentan con el recurso para comprar esas millonarias piezas de arte, de lo que se trata es de observar cómo ciertos productos culturales considerados de "alta" cultura comienzan a circular en objetos que pueden ser accesibles para diversos sectores sociales. Pero lo mismo sucede con ciertas artesanías, las cuales trascienden sus ámbitos locales para ubicarse en un mercado mundial, tal como sucede con los diablos de Ocumicho, Michoacán (México). García

\footnotetext{
${ }^{15}$ Durante el período posrevolucionario se intentó resaltar la importancia que habían tenido los indígenas en la conformación de la nación mexicana. Por ejemplo, en el caso del muralismo, Diego Rivera resalta la importancia de los indígenas en la historia de México, plasmando en sus murales formas de vida indígena.
} 
Canclini los pone de ejemplo para especificar que estas artesanías han sido resignificadas y se han convertido en obras de arte.

Por lo que se ha expuesto, la dicotomía tradicionalistas/modernistasmodernizadores se ha difuminado y, más allá de la amenaza que para los sectores tradicionalistas representaba la modernización, se ha demostrado que no se han anulado las tradiciones. En todo caso "la modernización disminuye el papel de lo culto y lo popular tradicionales en el conjunto del mercado simbólico, pero no los suprime", más bien expone cómo lo "culto" y lo "popular" entran en una lógica en la que ambos se apropian de estrategias para permanecer en un mercado simbólico: "Los movimientos populares también están interesados en modernizarse y los sectores hegemónicos en mantener lo tradicional, o parte de ello, como referente histórico y recurso simbólico contemporáneo" (García Canclini, 2009, p. 18, 257).

El proceso de hibridación que se da en las sociedades mostraría que los bordes para definir los límites entre culturas son difusos. Al interior de las naciones también están las fronteras porosas, también están presentes las pugnas por las narrativas. Esta hibridación entre sectores en apariencia antagónicos implica conflictos, imposiciones, desapariciones, es decir, no se puede asumir como el resultado de un "cruce feliz", o no al menos en todos los casos.

La perspectiva de una visión homogénea sobre el pasado respecto a una nación no tiene cabida en el devenir de los grupos sociales, ya que, como queda de manifiesto en el abordaje teórico de García Canclini, las sociedades se valen de distintas perspectivas, pasadas y presentes, para situarse en las diferentes configuraciones sociales, por lo que su estudio no responde a expectativas de homogeneidad, sino de heterogeneidad. 


\subsection{Teorías de la frontera: repensar la memoria y la identidad}

Borderlands/La Frontera... es considerado "un hito fundacional de los estudios de frontera" ${ }^{16}$ (Trigo, 2012, p. 151). Estudios de/sobre frontera (border theory) que desde finales de los ochenta cobraron relevancia en América Latina y Estados Unidos. Desde estos estudios, se han analizado fenómenos como la migración, las diásporas y los desplazamientos forzados. Si bien estos escenarios de migración y desplazamiento no son nuevos, sí "se ahondaron con los procesos de transnacionalización y globalización de las últimas décadas" (Basile, 2012, p. 121).

En un inicio, la generación de una "teoría de la frontera" estuvo focalizada sobre la problemática fronteriza entre Estados Unidos y México, esto provocó que muchos de los análisis y visiones sobre esta línea se pretendieran replicar en otras fronteras. Sin embargo, se ha señalado el peligro y el riesgo de esencializar los conflictos desatados en la frontera norte de México al querer abordar otras fronteras como si se presentaran conflictos parecidos (Grimson, 2004; Vila, 2001; Johnson y Michaelsen, 2003). En este sentido, Pablo Vila (2001) ha argumentado que incluso en el caso de la frontera entre México y Estados Unidos, los problemas son distintos dependiendo del lado en que se estudien, pues no es lo mismo vivir la frontera del lado mexicano, que habitarla del lado estadounidense.

A pesar de que no se puede hablar sobre una "teoría de la frontera" por lo que se ha señalado previamente, David E. Johnson y Scott Michaelsen reconocen el papel que han tenido los estudios chicanos para impulsar los estudios sobre la frontera y generar teorías sobre esta:

\footnotetext{
${ }^{16}$ Junto al texto de Anzaldúa aparece Border Writing de Emily Hicks, por su importancia en los estudios de la frontera.
} 
Configuración de una "memoria Nepantla" en Borderlands...

Maestría en Historia y Memoria

Universidad Nacional de la Plata

Los estudios chicanos, más que los estudios étnicos, los poscoloniales o los relativos a la zona limítrofe entre Estados Unidos y México, convirtieron el concepto de frontera en algo asequible e incluso necesario para los discursos más amplios de los estudios literarios norteamericanos, de la historia de Estados Unidos y de los estudios culturales en general (2003, p. 46).

Teniendo en cuenta estas consideraciones sobre los estudios de la frontera, se hará un análisis respecto al alcance que han tenido algunos de los aportes en este campo. En este sentido y de acuerdo a lo que se ha mencionado hasta el momento, abordar el tema de la identidad como tal pareciera entrar en contradicción con la perspectiva de la heterogeneidad cultural que se ha venido sosteniendo, así que resulta pertinente aclarar que la noción de identidad que se maneja se aleja de una visión unívoca y estática, justo porque este enfoque no alcanza a dar cuenta de los cambios que generan distintas dinámicas sociales. Por lo que se aborda la identidad desde lo que plantean algunos estudios de/sobre la frontera porque posibilitan una mirada heterogénea sobre la misma.

Para Alejandro Grimson, "una teoría de la frontera es una teoría de la cultura" (2003, p. 14), pero ¿qué entiende por frontera y por cultura? Sobre la frontera sostiene que no debe perderse de vista el sentido humano que tiene, pues, por ejemplo, cuando se clasifican los rasgos humanos, se inventan esas diferencias que generan "fronteras" entre los mismos. El problema con estos límites es que se olvida que son contingentes y frágiles, por lo que terminan formando parte de lo que se considera "inevitable" (Grimson, 2011, p. 26). Textos como el de Anzaldúa transformaron las concepciones sobre las fronteras, porque no sólo se plantearon en términos de cruce y límite, también se vislumbraron en términos de conflicto y desigualdades (2011, p. 131). 
La frontera no puede ser simplificada a una línea divisoria en donde de un lado están los buenos y del otro lado los malos, porque se tiene que admitir que, aun con las resistencias que en un determinado momento pueden surgir de uno o de otro lado, hay desplazamientos, hay circulación en ambos sentidos (2011, p. 129). De ahí que la frontera ya no se entienda sólo como línea divisoria entre territorios, sino como un espacio en donde se cruzan, intercambian e hibridizan las identidades y los universos simbólicos. Por eso, en un análisis sobre la frontera no se puede sólo pensar en términos de la lógica que impera con la migración, también tenemos que pensar en los receptores de la migración, cuál es el discurso que predomina, cómo conciben la frontera, cuál es la narrativa en torno a los territorios expulsores de migrantes, entre otros aspectos que determinan la construcción de las fronteras identitarias.

Sobre el término "cultura", el autor informa que existen diversas definiciones en el terreno de las ciencias sociales, pero "cultura" es un concepto que abarca hábitos, creencias y rituales, ya que un análisis profundo no sólo busca describir los elementos comunes en una sociedad, sino, adentrarse en las "configuraciones culturales" que enmarcan desigualdades y poderes que dictaminan las relaciones al interior de una sociedad y también en sus dinámicas con otros grupos (2011, p. 43). Asimismo, se debate los riegos que implica abordar el estudio sobre una cultura desde su contexto, pues eso supondría el aislamiento y asumir que existen límites fijos $y$, entonces, ¿cómo se explican los cruces, las filtraciones y las influencias que hay entre culturas?, en palabras del autor "¿cuál es la frontera de un contexto cuando los significados circulan?" (2003, p. 14).

Así, en esta dinámica de circulación que se da entre los elementos culturales que vuelven difusas las fronteras ¿cómo se puede pensar la identidad? Grimson indica que no se puede confundir cultura con identidad, porque si la cultura hace hincapié en prácticas, tradiciones y creencias, la identidad haría referencia a "los sentimientos de pertenencia a un colectivo y 
a los agrupamientos fundados en intereses compartidos" (2011, p. 139). La identidad se entiende, entonces, como la asunción consciente de elementos que generan pertenencia, de ahí que se hable de una "identificación". Sin embargo, no en todos los casos se podría estar hablando de una identificación consciente derivada de ese sentimiento de pertenencia, pues sabemos que hay ocasiones en las que se intenta a toda costa imponerla.

Para Russ Castronovo "la frontera es más que un sitio de dominación: es también un 'terreno diferenciado' surcado por 'corrientes discursivas diversas". Se trata de un espacio ambiguo que reditúa beneficios (y perjuicios) para quienes las cruzan y para las "formaciones ideológicas"17 que configuran las realidades sociales. Pero también esas "formaciones ideológicas" sobre la frontera están sometidas a una serie de conflictos que impiden que alguna de esas manifestaciones pueda declarar una "oposición absolutamente victoriosa" (2003, p. 207, 221). Aquí surgen preguntas como ¿la finalidad de los conflictos culturales surgidos en la frontera es alzar la bandera de la victoria? ¿De qué victoria estamos hablando? ¿Del reconocimiento de una identidad por parte de otros grupos sociales? ¿De la imposición de una identidad sobre otros grupos sociales? Se entiende que la idea es evidenciar que aun cuando se intente, por ejemplo, imponer una identidad "de manera absoluta", esa pretensión es imposible; sin embargo, también se presta para pensar cuál es el alcance de los grupos sociales que

\footnotetext{
${ }^{17}$ Para Russ Castronovo, la nación es una "formación ideológica" que suele mirar las fronteras con intenciones de sacar provecho anexando más territorio. Pero también están quienes buscan cruzarla con fines distintos. Es evidente que aunque en ambas dinámicas se busque "sacar provecho", la que busca anexar más territorio no tiene una relación simétrica con los que sólo buscan cruzarla. En este sentido, las fronteras habilitarían una doble tensión: los que buscan cruzarla y los que buscan expandirla anexando más territorio. En el caso de la frontera con México esa tensión se mantiene en ambos sentidos, pues a pesar de que Estados Unidos ya anexó parte del territorio mexicano, la amenaza de la invasión con "fines de seguridad" ha sido una constante en los últimos años, sobre todo con el auge del conflicto por el narcotráfico y la llegada de Donald Trump a la Casa Blanca; además, aunque el fenómeno migratorio ha disminuido en los últimos años, la frontera norte de México sigue siendo un punto de cruce para los latinoamericanos.
} 
disputan la legitimidad de su identidad dentro de la narrativa dominante en la que están insertos.

Como ya se ha mencionado, para Anzaldúa border es la línea divisoria entre territorios y borderlands es el territorio de cruce que desarma la lógica expulsiva de la frontera. Esta relación border/borderlands es retomada por Abril Trigo a través de los términos "frontera" (border) y "frontería" (borderlands). La frontera es "lo que cierra y delimita, lo que obstruye y construye identidades, lo que define la civilización más acá de la barbarie". Separa a un estado del otro, es el espacio donde se establece quiénes son los ciudadanos y quiénes son los extranjeros, quiénes constituyen un "nosotros" y quiénes son esos "otros" que ponen en "peligro" a la nación. La frontera es un muro, una separación, una valla, un sistema de exclusión/inclusión, una línea que delimita lo legal de lo ilegal. En cambio, la frontería es un territorio donde se dan los cruces culturales, es el espacio donde se hibridizan las identidades y hay circulación e intercambio de significados culturales. De esta forma, "la frontera legisla la razón de estado; la frontería es indiferente a la nación; la frontera es marca de Historia, la frontería habilita memorias fragmentarias" (1997, p. 80, 81). En este sentido, la frontera es "permeable y hermética a la vez, [...] crea y renueva sus códigos para cada grupo social, de acuerdo con la disímil distribución de los capitales económicos, sociales y culturales" (Vizcarra: 2005, p. 67, 76).

De esta forma, los estudios sobre la frontera no sólo indagan la concepción de ésta como límite geográfico-político, sino, también como un espacio desterritorializado en donde las culturas se encuentran y reinventan. Por tal razón, las fronteras representan actualmente el espacio donde los procesos globales, económicos y culturales se muestran con mayor intensidad (Garduño, 2003).

Hugo Vezzetti menciona que las disputas por la identidad son al final también disputas sobre las memorias sociales generadoras de éstas. La identidad puede considerarse como un elemento social blindado a la incertidumbre "o bien puede constituirse como un espacio de reconocimiento 
y descubrimiento, una construcción capaz de sostener una acción más lúcida y renovadora del pasado" (2002, p. 33). Por lo que pensar la memoria y la identidad desde la noción de frontería/borderlands permite vislumbrar los cruces, las fugas, las filtraciones y los conflictos que se dan en las sociedades.

Las interpelaciones a una narrativa unívoca y la demanda por incluir las alteridades de diversa índole; la puesta en crisis de las dicotomías excluyentes entre tradicionalismo y modernización; la visibilización de las tensiones y conflictos al interior de una nación; la diseminación de dispositivos de hibridación junto con la configuración de una textualidad que deviene un espacio de frontería, atravesado por cruces, intercambios, mezclas y sacudido por disputas, fugas y demandas, constituyen principios constructivos en Borderlands....

\subsection{Memorias en conflicto}

Maurice Halbwachs hace una distinción entre "memoria individual" y "memoria colectiva" (2004). Si bien ya ha sido muy criticada la noción de "memoria colectiva" porque implica la subordinación de las memorias individuales a la colectiva, lo relevante es la justificación de cómo la memoria trasciende el aspecto de facultad individual de recordar para llegar al terreno social de generación, transmisión y reinterpretación de recuerdos. En este sentido, para Michael Pollak la memoria es la operación a través de la cual algunos grupos esperan resguardar determinados hechos y versiones del pasado que les permitan mantener un cierto grado de cohesión como grupo (2006, p. 25). El señalamiento de "un cierto grado" indica que esos hechos y versiones sobre el pasado están mediados no sólo por reinterpretaciones de los propios grupos sociales, sino por los cruces que se tienen con otros grupos. Si las líneas culturales son difusas ¿por qué no serían también difusas las líneas que separan a una memoria de otras? 
Pollak afirma que cuando la historia oral comenzó a estudiar a los sectores marginados y a las minorías, empezaron a surgir lo que denomina "memorias subterráneas" que se oponen a la "memoria oficial" o nacional. Para él, esas "memorias subterráneas" emergen en momentos de crisis e inician disputas. Pero mientras llega ese momento, esas memorias luchan contra el olvido, al que algunas veces parecen estar condenadas, transmitiendo sus recuerdos entre círculos cercanos (familiares y amigos), esperando el momento en el que haya una redistribución de las cartas políticas e ideológicas (2006, p. 18, 20).

Para Enzo Traverso la memoria es una construcción permeada por las vivencias posteriores que terminan por modificar los recuerdos: "La memoria, sea individual o colectiva, es una visión del pasado siempre mediada por el presente". El autor considera que es fundamental cuestionar esa subjetividad de la memoria no para desacreditarla, sino para establecer un horizonte de comprensión que permita "inscribirla en un conjunto histórico más vasto". De ahí que aparezca, de manera inevitable, la figura del historiador, quien se convierte en un guardián de la memoria al abandonar la visión positivista de la historia, lo que lo convierte en un sujeto activo en la formación de una "memoria colectiva", trascendiendo, pero no desacreditando, la memoria individual. Traverso indica que esta "memoria colectiva" no es unívoca, es plural y conflictiva $(2007$, p. $74,77,78)$.

Asimismo, hay memorias que son sostenidas por los estados o por ciertas instituciones, mientras que otras están ocultas o prohibidas, de ahí que marque la diferencia entre memorias "fuertes" y memorias "débiles" ( $p$. 86). Sin embargo, esta diferenciación no significa un factor determinante, es decir, una memoria "débil" no está condenada a serlo siempre, ni una memoria "fuerte" tiene garantizado su estatus como tal.

Por su parte, Tzvetan Todorov en Los abusos de la memoria (2000) habla sobre una "memoria literal" y una "memoria ejemplar". La "memoria literal" sería aquella que no permite ir más allá de lo que se podría considerar una interpretación al pie de la letra, por decirlo de alguna forma, 
de un hecho, o supone interpretar los hechos como si no cambiaran. Mientras que la "memoria ejemplar" permite reinterpretar ese pasado en el presente con miras hacia la construcción de un futuro, éste sería el tipo de memoria ideal en la medida en que se aprenden y se engendran lecciones para las generaciones herederas de esas memorias.

Todorov argumenta que toda memoria es selectiva, no hay una memoria total sobre algún acontecimiento ni una versión definitiva, esto implica una labor activa por parte de los grupos sociales a fin de mantener vivos los recuerdos que alimentan versiones sobre su pasado. "La memoria tiene entonces un papel altamente significativo como mecanismo cultural para fortalecer el sentido de pertenencia y a menudo para construir mayor confianza en sí mismos (especialmente cuando se trata de grupos oprimidos, silenciados y discriminados)" (Jelin, 2005, p. 224). Vezzetti también sostiene que "la memoria social es selectiva y recupera los sentidos del pasado a partir de marcos y soportes diversos" (2002, p. 16). La memoria tiene un doble horizonte al estar en el presente y en el pasado, por lo que esta posibilidad es la que permite hablar de un pasado que se transmite como herencia. Sin embargo, el peligro de esta transmisión es que se pretenda compactar ese pasado borrando de él las fracturas y así intentar imponer un presente falsamente reconciliado (Vezzetti, 2009, p. 14).

Vezzetti plantea la necesidad de trabajar en una "memoria justa", cuyo objetivo principal radica en la búsqueda de una sociedad más justa. Esta memoria conlleva la obligación de indagar sobre el pasado de una manera compleja, porque no se trata sólo de recordar lo que pasó, sino abordar cuál fue y es el papel del estado, de la sociedad y de otros sectores ante determinados acontecimientos. Lo que se pretende es restituir la memoria de las víctimas, dimensionar el daño y, de cierta forma, repararlo. El autor insiste en la urgencia de una "memoria justa" porque, en su análisis, considera que, en los últimos años en el contexto argentino, se ha hecho un "uso político del pasado" que se evidencia, sobre todo, "en contiendas electorales o en crisis coyunturales" (2009, p. 39). 
De esta forma, la "memoria justa" apuesta a un equilibrio entre el déficit y el exceso de memoria. También apela a los procedimientos judiciales (juicios contra responsables de los delitos perpetrados), pero no se conforma sólo con éstos, sino que aboga por una transformación de los ámbitos morales y culturales (p. 55), por lo que resulta insuficiente que el reclamo por el reconocimiento de un pasado sólo alcance los ámbitos políticos y judiciales. Ocupar esos recintos significa haber ganado un terreno importante, sin embargo, es necesario generar una conciencia para no quedar a merced de revanchismos. Las condenas judiciales, como sostiene Vezzetti, jamás repararán el daño hecho y tampoco se podrá encarcelar a todos, de ahí que la noción de "memoria justa" debe trascender este ámbito.

En cierto sentido, las "memorias subterráneas" (Pollak), las memorias "débiles" y "fuertes" (Traverso), la "memoria literal" y la "memoria ejemplar" (Todorov) convergen o dan pie a la "memoria justa" de Vezzetti, porque esta noción apuesta por el reconocimiento de las divergencias en las miradas hacia el pasado, pero sin perder de vista la necesidad de construir una sociedad más justa. La noción de "memoria justa" no borra los conflictos, ni tampoco pone en el mismo nivel a todas las memorias, como si todas fueran "legítimas", sino que cuestiona las movedizas arenas en las que pueden estar instaladas las políticas de la memoria pública.

También en Borderlands...Anzaldúa plantea la necesidad de una "memoria justa", porque no intenta sólo establecer una disputa pública respecto a otras memorias, ni legitimar a los chicanos sólo a partir de reivindicar algunas luchas a nivel político, sino que procura trascender esos dos ámbitos con la finalidad de que, en una primera instancia, se reconozca el pasado de abusos al que su comunidad ha sido sometida; $y$, en una segunda instancia, se asuma la legitimidad de su lengua y la posibilidad de reinterpretar algunos símbolos femeninos que han sido utilizados para justificar el sometimiento de las mujeres chicanas. 


\section{El testimonio como vehículo de las memorias}

Esther Cohen, en su texto Los narradores de Auschwitz, resalta la importancia del testimonio como recurso a través del cual los "testigos" no sólo dan cuenta de lo acontecido, sino que pueden dar vida y humanizar los acontecimientos pasados y presentes. En este sentido, "el testigo bien podría ser, en nuestro tiempo, quien viniera a ocupar el lugar de la resistencia, el de la oposición al olvido [...]". Una oposición que conlleva "la recuperación del habla", pero también significa un acto de justicia ante lo que "otros/as" no pueden o no han podido decir, por lo que el testimonio (en el contexto de actos de barbarie y represión) no se hace a título personal, ya que se invoca a un "nosotros/as", a una "comunidad". "Porque la justicia va estrechamente ligada a la capacidad de narrar y de relatar historias" (2006, p. 59,61$)$.

Borderlands... forma parte de los textos testimoniales, aunque va más allá de su límite, ya que en él Anzaldúa narra su existencia, lo que es vivir en una frontera y en una frontería. El libro se constituye también en un testimonio acerca de lo que es ser una mujer chicana y lo que significa reflexionar sobre las tradiciones heredadas. Con este texto la autora alza la voz frente a aquellos que han procurado silenciar su cultura, los que han intentado cortar su lengua, una lengua rebelde que no se subsume al que se considera el idioma correcto, sino que le permite reivindicar y decir lo que históricamente los chicanos no han podido comunicar. Así, recupera algunos de los acontecimientos de su "comunidad" en Estados Unidos y lo hace a través del spanglish. Por tal razón, el uso del testimonio se vuelve uno de los aspectos centrales del texto y se une a las voces testimoniales que denuncian e interpelan las posiciones de esos otros que en sus discursos y narrativas los ignoran, los intentan callar, los "destinan" al olvido.

Actualmente se reconoce la trascendencia e importancia del testimonio en la búsqueda de verdad y justicia en los grupos sociales, 
además de brindar la posibilidad de construir identidades grupales que permitan reivindicar y/o rechazar aspectos del pasado para que, en la medida de lo posible, se cuente con una visión propia y acorde con las luchas por la identidad que se han librado. Pero también el testimonio tiene el imperativo del recuerdo, de no olvidar las atrocidades y abusos que se han cometido (Cohen, 2006).

En la importante tradición latinoamericana del testimonio, Miguel Barnet, en su Biografía de un Cimarrón (1997), recoge el testimonio de un cimarrón que permite dimensionar la vida que en su momento llevaban los esclavos en la sociedad cubana y cómo estaban dispuestos a correr el riesgo de escapar y vivir una libertad plagada de riesgos, pero era esa libertad o morir como esclavo. Este testimonio también exhibió las tradiciones y creencias de los esclavos, no desde la visión hegemónica que solía satanizarlos y/o denigrarlos, sino desde la perspectiva de una persona que estaba inserta en el corazón de los esclavos.

Por su parte, el testimonio de Anzaldúa mostró cuestiones poco conocidas de la sociedad chicana desde la visión de una mujer. En este relato se reflejan aspectos culturales que ensalzan a los chicanos, pero también se exponen otros que cuestionan y critican la idiosincrasia del grupo, sin pasar por alto que su testimonio se focaliza, la mayor parte del tiempo, en el análisis del uso de la lengua para reivindicar la identidad chicana y recordar constantemente cuál es el origen de sus luchas como grupo. Este testimonio de Anzaldúa también observa cómo los chicanos realizan una comparación entre el conflicto que se generó con la llegada de los europeos al "Nuevo Mundo" y la invasión que ellos sufrieron cuando los territorios que ocupaban fueron "invadidos" por Estados Unidos y obligados a despojarse de lo que tenían, despojos no sólo en el sentido material, sino también de prácticas, tradiciones y lengua.

Martin Lienhard, en La voz y su huella (2003), indica que los europeos no fueron indulgentes con los nativos americanos respecto a la lengua, sino que a través de la escritura intentaron afianzar su visión del mundo, 
desdeñando la oralidad como herramienta para dar cuenta de los acontecimientos considerados trascendentes. De esta forma, los europeos "impusieron su sistema de comunicación oficial, basado en la preeminencia absoluta de la escritura alfabética" (p. 14). Pero los indígenas siguieron considerando a la memoria como un vehículo para transmitir sus relatos, aspecto que hizo posible el surgimiento "de una literatura alternativa" (Ferro, 2017 , p. 300). La sociedad chicana se vio inmersa en una marginalidad de este tipo, ya que pasaron de ser mexicanos con el español como lengua, a ser parte de otro país, con otra lengua y con exigencias de asimilación a la nueva cultura. Anzaldúa manifiesta lo poco común que era encontrar escritos del idioma en que se comunicaban los chicanos, ella misma se sorprendió cuando tuvo acceso a una novela en spanglish ${ }^{18}$. No existía propiamente una documentación que diera cuenta de una memoria escrita. Así su libro pretende testimoniar cómo lograron preservar una memoria como grupo a través de la oralidad, de algunas prácticas y de algunas tradiciones.

Volviendo a la cuestión testimonial del texto de Anzaldúa, de acuerdo a lo que menciona Lienhard, Borderlands... está inserto en lo que se denomina una literatura "alternativa", en donde se libran batallas semióticas, "espacios donde se redefinen, ficticia o ficcionalmente, los lugares respectivos de los 'vencedores' y de los 'vencidos'” (2003, p. 33). A diferencia de lo que aconteció con la llegada de los españoles al "Nuevo Mundo" cuando no existía un predominio de la escritura, sino que la oralidad era una de las fuentes principales de comunicación en el sistema de los indígenas, en la identificación como grupo social de los chicanos ya hay una conciencia de la importancia de la escritura, es decir, ya se asume que sin una tradición escrita es más difícil el reconocimiento de las luchas grupales, la preservación de una memoria y, por lo tanto, la construcción de una narrativa propia.

\footnotetext{
${ }^{18}$ La novela a la que hace referencia Anzaldúa es City of night de John Rechy, publicado en 1963. Un libro que abordaba abiertamente el tema de la homosexualidad.
} 


\section{La lengua como escenario de las memorias en pugna}

Una de las disputas más visibles en el marco de la nación es el de la lengua, no sólo cuando se trata de un idioma distinto se generan conflictos, también hay problemas en los usos de una misma lengua cuando no son vistos como los correctos por quienes establecen las normas "adecuadas". En este sentido, muchas veces el tema de la lengua es utilizado como un eje fundamental de una nación y para determinar quiénes quedan excluidos de la idea de ciudadanos simplemente por no hablar la lengua indicada. Un ejemplo de esto lo expone Ana Celia Zentella, en su artículo "La hispanofobia del movimiento 'inglés oficial' en los Estados Unidos para la oficialización del inglés" (1995), al describir cómo en la década de los ochenta resurgió con fuerza la discusión sobre si el inglés debiera ser la lengua oficial de los Estados Unidos, ya que este idioma es considerado parte de la identidad nacional. En 1981 se propone la "Enmienda a la Lengua Inglesa", una enmienda que contaba a nivel político con un amplio respaldo del sector republicano ${ }^{19}$ al coincidir con los argumentos propuestos por quienes defendían ( $y$ defienden) que el inglés tiene que ser la lengua oficial, pero dicha Enmienda no fue aprobada. Dentro de las "razones" que se utilizaron para su defensa se encuentra la siguiente:

los estadounidenses que no hablan el inglés estándar son deficientes, y aquéllos que hablan otras lenguas son menos iguales aún. Consecuentemente, en conformidad con el cada vez más popular recurso

\footnotetext{
${ }^{19}$ En Estados Unidos predominan dos partidos políticos: Los Demócratas y Los Republicanos. Así, cuando se menciona "sector republicano" se hace referencia al partido político Republicano, que fue fundado en 1845. En las últimas décadas, a este partido se le ha asociado con políticas económicas neoliberales y con políticas sociales conservadoras (Aguirre, 2001). De ahí que algunas de las posturas republicanas en temas migratorios y de derechos humanos sean consideradas conservadoras.
} 
americano de las soluciones legales, los no hablantes de inglés no son dignos de igual protección ante la ley. (1995, p. 26)

Los chicanos con el spanglish entraban en ese estatus de los estadounidenses deficientes y no eran, de acuerdo a la cita, ciudadanos "iguales", eran un poco más iguales que los que no hablan el inglés, pero no eran considerados ciudadanos norteamericanos plenos. Pero ¿quiénes eran los que defendían la idea del inglés como lengua oficial? La autora ubica a distintas organizaciones de la sociedad civil, entre las que se encontraban English Only y US English, principalmente, apoyadas por amplios sectores de la población blanca y grupos conservadores. Si bien estas organizaciones enfocaban sus críticas a todas las lenguas que no fueran el inglés, Zentella considera que el objetivo principal era la comunidad hispana. Este razonamiento lo sustenta en el hecho de que en sus propagandas las organizaciones mencionadas usaban como ejemplo a la gente latina. Sin embargo, los argumentos trascendieron el uso de la lengua y aprovecharon ese debate para introducir otros aspectos de la comunidad latina, ya que estos grupos en defensa del inglés alegaron que culturalmente los hispanos tienen una serie de prácticas que amenazan la democracia estadounidense, como los es la cultura del soborno en América Latina, es decir, el soborno se asume como una cuestión ya enraizada en los latinoamericanos.

Volviendo al tema de la lengua, para Zentella hay una distorsión en las organizaciones que critican la presencia del español en los Estados Unidos, ya que hubo regiones, sobre todo al sur, donde predominaba el español. Este aspecto no es novedoso si tenemos en cuenta que Estados Unidos se apropió de una parte del territorio mexicano, ese no es un fenómeno de las migraciones de las últimas décadas, sino que data de hace más de un siglo. 
Otro de los problemas que encarna esta "hispanofobia" es que no suele distinguir las variaciones en el español que hablan los latinos, mucho menos sus dialectos: "La hispanofobia no distingue entre los coloradans, cuyas raíces en los Estados Unidos vienen de hace más de 200 años y los ilegales recién llegados, o entre la clase media de los cubanos blancos de Florida y los puertorriqueños pobres no blancos de Nueva York" (Zentella, 1995, p. 59).

Este tipo de problemáticas con la lengua suele presentarse en muchas naciones, pero no siempre son respaldados por los gobiernos, aunque sí por amplios sectores de la población. En la actualidad muchos de los sectores considerados marginados han logrado alzar la voz y exigir el reconocimiento de su lengua. Esto sólo ha sido posible por "la lengua rebelde", una lengua que, con el paso del tiempo y a pesar de los embates por "cortarla", ha logrado sobrevivir. Sin embargo, no es una tarea fácil, la idea del monolingüismo sigue dominando en muchos países, sin entender la pobreza cultural que eso significa. Las lenguas se enriquecen con el cruce lingüístico, y es en este cruce cuando se ponen en entredicho las pretensiones conservadoras de algunos defensores del monolingüismo. George Steiner, en Logocratas (2007), menciona que el monolingüismo es una de las pobrezas de los Estados Unidos, un país que podría enriquecerse de la diversidad de lenguas que han confluido a lo largo de la historia, pero se ha empecinado por defender la supremacía del inglés, aspecto que compara con Europa, donde en la mayoría de los países hablan al menos dos lenguas. Esta también es una de las críticas principales que realiza Anzaldúa en su texto, donde sostiene que el parámetro para saber si los chicanos han logrado ganar en la constitución de su identidad lingüística está dado por la aceptación y penetración del spanglish en la cultura anglosajona dominante, prevaleciente en los Estados Unidos. 


\section{¡Si no lo usas se olvida!}

Como ya se ha mencionado, la cuestión del spanglish es central en Borderlands..., pues es a través de esta lengua que se narra la forma en que los chicanos libran varias batallas, además de que también exige ser reconocido. En este punto, Anzaldúa es tajante, ya que si el spanglish sigue considerándose una lengua ilegítima, entonces su grupo sigue siendo visto como un sector no reconocido en el contexto de la sociedad estadounidense.

Martin Lienhard (2003) sostiene que con la llegada de los españoles a América Latina hubo un desplazamiento de las lenguas indígenas para dar paso a la de los colonizadores. Sin embargo, eso no significó que se perdieran las lenguas "nativas" o que las lenguas que se imponían no se hubiesen enriquecido con el cruce. Las resistencias para adoptar otras lenguas estuvieron del lado de los invasores, aspecto que al parecer no representó un "problema" significativo para los indígenas, pues se comunicaban a través de la lengua que impusieron los colonizadores en ciertos contextos, pero seguían hablando su lengua nativa en otros espacios.

Para Lienhard, en las sociedades donde hay un bilingüismo suele presentarse un fenómeno conocido como diglosia. Este fenómeno "remite a la coexistencia, en el seno de una formación social, de dos normas lingüísticas de prestigio social desigual". Un ejemplo de esto lo encontramos en las sociedades de la Colonia, pero también lo hallamos en el texto de Anzaldúa con el caso de los chicanos en los Estados Unidos, donde existe una relación desigual entre el inglés y el spanglish ${ }^{20}$. Así, "la diglosia es una práctica específica, asimétrica, del bilingüismo. En sus contactos con los representantes del poder, los hablantes nativos de la norma subalterna se suelen ver obligados a servirse, aunque la desconozcan, de la norma alta"

${ }^{20}$ Como se ha señalado, el spanglish surge de la combinación de varias lenguas, como tal tiene una relación desigual frente al inglés, pero también frente al español al considerar que no es una lengua "correcta". 
(2003, p. 147,148). Norma alta entendida como la lengua de la hegemonía, de los que detentan el poder de indicar cuál es la "correcta". A pesar de esta relación desigual, lo que también intenta mostrar Lienhard es cómo, a pesar de las intenciones de reprimir y "cortar", las huellas de una lengua persisten por su uso, un uso no aceptado, pero que desde la práctica no reconocida puede "preservarse", como es el caso del spanglish, que se derivó, principalmente, del uso de dos lenguas: inglés y español. En este sentido, se sabe que los chicanos tuvieron que hacer un esfuerzo por conservar su lengua, ya que sin su uso, sin su transmisión ésta corría el riesgo de desaparecer, de ser olvidada.

\subsection{Una mirada a la sociedad chicana}

Cuando se revisan algunos documentos para acercarse a una idea más o menos uniforme de lo que es la sociedad chicana, esa unidad no existe, como casi en ninguna sociedad. Lo que sí se percibe es una reivindicación de los movimientos chicanos por la exigencia de derechos y de reconocimiento. Así, por ejemplo, Roberto Rodríguez (1996, p. 1) menciona que, para algunos historiadores, los "orígenes" del movimiento chicano se ubican en 1521 cuando las fuerzas de Cuauhtémoc se enfrentan a los invasores españoles. Pero para otros, arranca con el final de la guerra entre México y Estados Unidos en 1848 (Gutiérrez, 1993, p. 47). Ahora bien, fue en la segunda mitad del siglo XX, específicamente en la década de los sesenta, cuando este movimiento chicano focalizó sus demandas y generó una base social de lucha que no tenía antecedentes.

Para Ramón Gutiérrez, la década de los sesenta representa un quiebre no sólo en la historia de los que en ese momento se asumían como 
mexicoamericanos ${ }^{21}$, sino también para el Black Power (sintagma que se utilizó en la década de los sesenta para defender los derechos de los afroamericanos principalmente en Estados Unidos). El autor considera incluso que el movimiento chicano de esos años tuvo su impulso a raíz de las protestas de los afroamericanos. El punto crítico, y que orquestó estos movimientos, se ubica en la "promesa" rota que representó no alcanzar el "Sueño Americano" después de la Segunda Guerra Mundial. Los mexicoamericanos que pelearon en la Segunda Guerra Mundial creyeron que al regresar lograrían una movilidad social y serían parte de las "bonanzas" económicas de los Estados Unidos. Sin embargo, sólo para los "blancos" fue una realidad ese sueño (1993, p. 44).

De ahí que en los sesenta se articuló un movimiento social que denunciaba el relegamiento que sufrían los chicanos en distintos ámbitos de la sociedad estadounidense. En este sentido, hubo dos grandes vertientes de este movimiento. Por un lado, estaba el movimiento estudiantil que buscaba ocupar espacios que regularmente les eran negados en las instituciones educativas, principalmente las universidades. Por otro lado, estaba la lucha por los derechos laborales, principalmente la de los trabajadores agrícolas (Rodríguez, 1996, p. 1).

Ahora bien, una de las críticas más comunes a los inicios de la lucha chicana, y que marca otro quiebre dentro del mismo movimiento, es que los dirigentes varones no reconocían un rol activo de sus compañeras en la búsqueda de derechos y en la construcción de la identidad grupal (Blackwell, 2008, p. 351). A pesar de esto existen evidencias de que al interior del movimiento un grupo de mujeres se posicionó y cuestionó el "machismo" de sus compañeros, que las condenaba a asumir los roles que tradicionalmente habían ocupado las mujeres chicanas: ser madres y dedicarse al cuidado abnegado de los hijos.

\footnotetext{
${ }^{21} \mathrm{En}$ algunos textos este término aparece como "mexican-american" y es utilizado para hacer referencia a los mexicanos que migran a los Estados Unidos y a los hijos de mexicanos nacidos en ese país.
} 
Por ejemplo, el discurso [...] creó una posición contradictoria para las mujeres en la que eran vistas como las portadoras de la tradición, la cultura y la familia, y a la vez eran borradas como sujetos de derechos políticos. En el movimiento, la construcción del género sexual para las mujeres estaba basada en lo que se ha llamado "la chicana ideal" (Blackwell, 2008, p. 367).

Otro ejemplo de la crítica feminista hacia el movimiento lo encontramos en el poema "Machismo is part of our culture", de Marcela Christine Lucero-Trujillo (citado en Ruiz, 2008, p. 120), en donde se arremete contra la naturalización del "machismo" como parte intrínseca de la cultura chicana, ya que ellas no están dispuestas a asumir esa justificación. De esta forma, una mirada a la sociedad chicana no puede pasar por alto el papel trascendente que las mujeres tuvieron en el movimiento al deconstruir gran parte de los presupuestos culturales que las relegaban básicamente a un papel pasivo dentro de la sociedad chicana.

\section{“Aztlán" en la narrativa chicana}

Los movimientos sociales gestados en la década de los sesenta, en cierto sentido, demandaban la inclusión de los chicanos en la sociedad estadounidense para poder desenvolverse en distintas áreas que hasta entonces eran propias de una sociedad angloamericana (educación, política, economía), es decir, no se trataba sólo de lograr mejoras en las condiciones de vida, sino de acceder a una plataforma común de derechos que les brindara la posibilidad de incidir y ocupar espacios negados a los chicanos 
hasta ese momento, exceptuando a aquellos que a través de la asimilación gozaban de derechos, pero a costa de "mimetizarse" con los valores de la sociedad blanca.

Las narrativas chicanas, en la búsqueda de su identidad, parten del mito fundacional "Aztlán" que les ha permitido teorizar los rumbos por los cuales ha caminado y pretende deambular el grupo.

La leyenda cuenta que la tribu azteca, guiada por su dios tutelar Huitzilopochtli, emigró hacia el sur de su antigua patria Aztlán para hallar la tierra prometida en el Valle de Anáhuac. Aztlán, 'tierra blanca' del norte, es ahora símbolo de la tierra que ocupan los chicanos y que consideran suya (Morales, 1978, p. 99).

Luis Leal, en su artículo "El concepto de Aztlán en la poesía Chicana" (2000), argumenta que "Aztlán" puede ser concebido como un lugar geográfico al sur de los Estados Unidos o también es un símbolo a través del cual se articula la identidad de los chicanos. "Aztlán" en sentido geográfico se refiere al territorio que habitaron las culturas ancestrales que dieron vida a las grandes culturas prehispánicas del México antiguo. Este espacio estaría ubicado al sur de los Estados Unidos, específicamente en algunos de los territorios que le fueron quitados a México a partir de la firma del Tratado de Guadalupe-Hidalgo en 1848. En este sentido, el mito de "Aztlán" plantea el retorno a ese lugar, un regreso simbólico que conlleva rememorar cómo fueron despojados de esos territorios.

El mito de "Aztlán" cuestiona que a los chicanos se les trate como "extranjeros" en lo que consideran es su "propia" tierra, donde se inició el trayecto de sus antepasados (indígenas). De esta forma, con la presentación 
del ambicioso proyecto "Plan Espiritual de Aztlán"22, en 1969, lo que se pretendía era "una recuperación de la herencia cultural mexicana e indígena para crear una conciencia positiva en el chicano que lo incite a la acción contra la injusticia" (Martín-Rodríguez, 2006, p. 50).

Uno de los principales problemas con el que se enfrentaron quienes pretendían construir una narrativa chicana fue la "asimilación" cultural a la sociedad estadounidense blanca, pues algunos sectores consideraban que la "asimilación" era una condición para ser aceptados como ciudadanos plenos. Sin embargo, dicha asimilación sólo la lograban unos pocos, y esos pocos tenían características muy específicas. Por ejemplo, Anzaldúa en La Prieta testimonia que para su madre el color piel oscura la identificaba como india y un atuendo sucio la hacía parecer mexicana "puerca".

"No salgas al sol", mi mamá me decía cuando quería salir a jugar. "Si te pones más oscura pensarán que eres una india. $Y$ no te ensucies la ropa. No quieres que la gente diga que eres una mexicana puerca". Nunca reconoció que aunque ya éramos americanos por seis generaciones, aún éramos mexicanos y todos los mexicanos son parte indios (1988, p. 157).

22 El Plan Espiritual de Aztlán es un manifiesto que establece las bases para unificar el movimiento chicano. En este plan se afincan las bases principales del movimiento: "el chicano es de origen indígena" y "sus abuelos fueron aztecas que emigraron hacia el sur" (Leal, 2000, p. 218). Fue lanzado durante la Conferencia de Denver en 1969. En esta conferencia se estableció una base organizada para seguir impulsando el movimiento chicano. También surgió el Movimiento Estudiantil Chicano de Aztlán (MECHA), una de las organizaciones que ha luchado por los derechos de los chicanos. 
Por su parte, Cherríe Moraga ${ }^{23}$, en "La güera" (1988), confirma estos mismos prejuicios, pero desde la posición de la "blanca", desde la mujer que ha crecido en un contexto en el que lo "blanco era lo correcto" y lo "prieto" ocupaba la zona de vergüenza, marginación e ignorancia.

\section{La compleja asimilación en la sociedad chicana}

Si bien, como ya se ha indicado, una de las principales demandas de los chicanos era el reconocimiento y la inclusión en la sociedad "gringa", tenían claro que esa inclusión no implicaba el abandono de creencias, prácticas y tradiciones relacionadas, principalmente, con la cultura mexicana. Sin embargo, otros sectores de mexicoamericanos demandaban la asimilación cultural como forma de acceder a las "bonanzas" de la sociedad anglosajona estadounidense.

Ahora bien, ¿qué se entiende por asimilación cultural? Para Roberto Herrera Carassou, la asimilación "implica la subordinación de una cultura a otra con toda la carga ideológica de etnocentrismo que ello representa" (2006, p. 162). En los inicios del movimiento chicano ya se criticaban las posturas asimilacionistas reflejadas, sobre todo, en la literatura mexicoamericana con libros como Pocho (1959), de José Antonio Villarreal, texto emblemático sobre este tema y en donde se refleja cómo para algunos de los hijos de mexicanos nacidos en Estados Unidos resultaba algo negativo que otros hijos de mexicanos se negaran a asumir la cultura

${ }^{23}$ Cherríe Moraga es una de las escritoras chicanas más influyentes. Su madre, quien tuvo un impacto relevante en su vida, tiene ascendencia mexicana y su padre es "gringo". Ella es de piel blanca, por lo que remarca la posición de privilegio que implicaba nacer con ese color y cómo eso contribuyó a que los primeros años de su vida se sintiera parte de la sociedad angloestadounidense. Sin embargo, su lesbianismo la lleva reflexionar sobre el lugar de opresión generado por el color de piel y las preferencias sexuales: "Mi lesbianismo es la avenida que me ha permitido comprender mejor el silencio y la opresión, y sigue siendo el más claro recordatorio de que no somos seres humanos libres" (1988, p. 21). 
anglosajona estadounidense. En este sentido, el término "mexicoamericano" se utilizaba para describir de forma general la migración de personas de México a Estados Unidos, pero también hacía referencia a aquellos individuos que no deseaban asumir la identidad chicana. Esto queda reflejado en el análisis comparativo que hace Francisco Javier Cortázar Rodríguez entre el "chicano" y el "mexicoamericano" cuando especifica que este último es usado como una opción para denominar a la población de origen mexicano en Estados Unidos y tiene, desde su perspectiva, "un carácter más asimilacionista a la cultura norteamericana, es de carácter conservador y apolítico, siendo usado sobre todo en Texas" (2004, p. 128).

A quienes se consideraba que habían asimilado la cultura norteamericana se les llamaba "pochos". Esta denominación era utilizada para referirse a los individuos "agringados" que renegaban de la cultura mexicana. La distinción del pocho como el que había asimilado la cultura norteamericana venía de los propios migrantes y descendientes de estos, ya que en México a todos los hijos de migrantes mexicanos que nacieron en Estados Unidos, o se naturalizaron como ciudadanos de aquel país, se los llamaba "pochos". Nombre que, en cualquier caso, tenía una connotación negativa ya sea para una parte del grupo o para la totalidad, debido a que "se aplicaba para denigrar a individuos considerados traidores a su pueblo y su cultura, ridiculizando su adopción de rasgos angloamericanos" (Hernández, 1993, p. 41).

Ser "pocho" era mal visto por la comunidad a la que se pertenecía, ya que se consideraba una forma de renegar del sistema de valores con el cual se identificaba la comunidad de "origen". Se tiene registro de que este apodo "aparece como denominación públicamente reconocida en libros, periódicos, reseñas teatrales y canciones chicanas durante la década de 1920" (Hernández, 1993, p. 39).

De acuerdo a lo que se ha descrito, el pocho no tenía la intención de búsqueda de una identidad como grupo social, según las investigaciones de autores como Hernández (1993) y Hernández-Gutiérrez (1994), ya que su 
objetivo era la asimilación a la cultura estadounidense: "Al pocho se le asociará frecuentemente con ese estigma lingüístico y cultural, y su retrato también puede incluir la representación de la deshonestidad, en contraste con las virtudes implícitas en la observación de las normas tradicionales mexicanas" (Hernández, 1993, p. 33). Sin embargo, la forma de hablar y de ser del pocho es una de las reivindicaciones que hará Anzaldúa, indicando que cuando ella habla el inglés muchas personas de su comunidad la han tachado de traidora, de pocha, pero ser pocho es también una forma de ser del chicano.

En este sentido, Anzaldúa trabaja el tema de la asimilación cultural no desde una perspectiva negativa, como regularmente se venía haciendo, sino que intenta desentrañar cómo se puede articular una identidad que retome aspectos de la cultura estadounidense y la mexicana, es decir, Anzaldúa no propone una identidad que sólo recupere aspectos de la cultura mexicana, sino que se deben tener en cuenta las culturas que confluyen en la tradición chicana. Su postura no será, entonces, la de rechazo hacia quienes eran considerados asimilados a la cultura dominante, sino que reflexiona sobre los aspectos que llevan a determinados sujetos a buscar la asimilación cultural.

\section{La rebeldía del "Pachuco"}

Para Guillermo Hernández, en su libro La Sátira Chicana, la figura del "pachuco" se remonta a un grupo de jóvenes en el sur de los Estados Unidos, específicamente en el Paso, Texas, que a inicios de los años treinta del siglo pasado tuvieron una fuerte influencia del caló ${ }^{24}$ mexicano. Asimismo, "el término pachuco tiene un significado más específico, puesto

${ }^{24}$ El caló viene del argot popular que se utiliza en los barrios, principalmente de la Ciudad de México, pero que en el caso del pachuco se ha resignificado de una forma muy particular. 
que se refiere a un estilo de vestimenta, al uso de la jerga del bajo mundo y a una actitud heterodoxa hacia las normas, tanto dentro como fuera de la comunidad chicana" (1993, p. 52).

Esta figura, dentro de la sociedad chicana, es una de las que más ha levantado polémicas debido a esa actitud mencionada por Hernández, o a formas de ser que no siempre son bien vistas, basta recordar las reflexiones que sobre el pachuco realiza Octavio Paz, en el Laberinto de la Soledad (2004). Paz menciona que durante su estancia en los Estados Unidos el grupo que más le llamó la atención fue el de los pachucos, precisamente porque ellos encarnan una serie de contradicciones y transgresiones que son poco comunes.

Para Paz, los mexicanos en Estados Unidos son personas que no han logrado integrarse a esa sociedad, no porque ésta no se los permita, sino porque mantienen ese aire rebelde que les impide asimilarse. El problema se agrava porque estos mexicanos reniegan de serlo, se avergüenzan de su pasado mexicano, por lo que terminan en un lugar intermedio (entre México y Estados Unidos), y ese espacio intermedio, lleno de inquietudes e inseguridades es lo que ha engendrado al pachuco. Para el autor en sus disertaciones sobre la identidad del mexicano, el pachuco es una de las formas de ser del mexicano.

Al no ser aceptado en la sociedad estadounidense, el pachuco exagerara su personalidad como una forma de llamar la atención: "El pachuco ha perdido toda su herencia: lengua, religión, costumbres, creencias. Sólo le queda un cuerpo y un alma a la intemperie, inerme ante todas las miradas. Su disfraz lo protege y, al mismo tiempo, lo destaca y aísla: lo oculta y lo exhibe" (p. 17). En palabras de Paz, este grupo social ha hecho poco para ser integrado a la sociedad estadounidense, en comparación con la comunidad afroamericana, que ha hecho lo posible por integrarse a la sociedad. De cierta forma, le parece incomprensible que los mexicanos, a pesar de no haber "sufrido" como los afroamericanos, no se hayan esforzado para integrarse a la sociedad estadounidense. 
El pachuco ocupa un lugar de rechazo en dos sentidos, por un lado, la aversión que él tiene hacia algunos sectores de la sociedad estadounidense, y por otro lado, la segregación que su forma de ser genera en la sociedad en que se encuentra. La no aceptación de este individuo se debe a la posibilidad de transgresión que encarna. El problema radica, según Paz, en que el pachuco es incapaz de proponer, su postura consiste en colocarse en un lugar distinto a los estándares sociales de la cultura en la que se encuentra inserto. Es decir, no saca provecho de la personalidad transgresora que le ha adjudicado la sociedad estadounidense, se queda en una especie de inmovilismo y su figura sólo remite a un grado de violencia por su aspecto físico, pero no la lleva más allá.

Al igual que el pocho, Anzaldúa también reivindica la forma de ser del pachuco, reconociendo la influencia que ha tenido el lenguaje de éste en la conformación de una lengua de frontería (1987, p. 56).

\section{El término chicano: una propuesta de identidad}

En los años previos al inicio del movimiento la palabra "chicano" tenía una connotación peyorativa al ser la forma en que se designaba a un mexicano de clase inferior. Como se ha indicado, "mexicoamericano" refería a alguien nacido en Estados Unidos de ascendencia mexicana o a alguien que se había naturalizado estadounidense (Ramírez, 2008, p. 93).

Cuando se reivindica este término, se establece un "consenso" 25 que estipula que ser "chicano" tiene que ver con asumirse como tal y no con haber nacido en los Estados Unidos, con tomar conciencia sobre las luchas chicanas con la finalidad de construir una narrativa que les diera identidad, lo cual no significa que se trate de un grupo homogéneo ni que enarbole una

\footnotetext{
${ }^{25} \mathrm{Al}$ menos esas son las posturas que asumen quienes defienden que las identidades deberían ser impuestas.
} 
identidad unívoca. De hecho, al bucear en la historia de los chicanos, se puede observar cómo se ha mantenido un impulso combativo y crítico dentro del grupo.

Cuando México pierde gran parte de su territorio (lo que actualmente es Arizona, Nuevo México, Texas, California y Colorado), aproximadamente cien mil mexicanos pasaron a formar parte de tierras extranjeras y además dejaron de ser propietarios de tierras para convertirse en una minoría explotada que trabajaba, en muchos casos, en lo que fue su antigua propiedad (Arellano Aguilar, 1982).

A pesar de las condiciones desfavorables que tuvieron los mexicanos después de que perdieron sus tierras, hubo resistencia por parte del grupo como lo indica María Isabel Arellano Aguilar: "de 1848 a 1875, aproximadamente, se caracterizó por la resistencia legal y extralegal [...] se rebelaron clamando la justa aplicación de la ley que hasta entonces se les había negado" (1982, p. 45). Sin embargo, en los años posteriores se agravaron las condiciones de los chicanos, sobre todo a raíz de la Gran Depresión del año 1929, ya que se fue excluyendo cada vez más a este grupo, relegándolo a actividades de producción primaria bajo una total desprotección. En estas circunstancias, los chicanos fueron objeto de una serie de violaciones. Una de estas, la que más suspicacia engendró en los chicanos en los años treinta, fue la de las deportaciones que comenzaron a afectarlos, no importaba si se era ciudadano o no. Las redadas, gran parte de éstas en los campos, levantaban a una cantidad considerable de "migrantes" con el fin de repatriarlos: "La repatriación de los años treinta estableció las bases de los recelos y la intranquilidad de la población chicana de hoy en día" (1982, p. 46).

Sin embargo, esa desconfianza no sólo proviene de las tentativas por repatriar al mayor número de chicanos a territorio mexicano, sino que también se sustenta por el lugar incómodo que ocupan del lado norteamericano, es decir, su historia refleja que no eran una sociedad 
deseada para los "gringos". Se los percibe como mexicanos portadores de todos los defectos que lo largo de muchos años se les han adjudicado.

La frontera entre México y Estados Unidos, como línea divisoria impuesta luego de la firma del Tratado de Guadalupe-Hidalgo en 1848, no solo se encargó de separar territorios, sino también de dotarlos de valores dicotómicos cargados de un contenido moral, cuyo polo positivo sería "estadounidense-blanco-clase media" y el negativo, "mexicano-piel de color-pobre" (Martín, 2009, p. 136).

Pero ¿qué aspectos se pueden considerar para identificar elementos propios de los chicanos? Hay distintos factores que es posible rastrear desde la firma de Tratado de Guadalupe-Hidalgo y que han permanecido hasta el día de hoy. Constituyen un grupo con un pasado muy ligado a México (ya sea porque consideran que sus ancestros habitaban los territorios tomados por Estados Unidos o porque tienen una historia migratoria), también siguen presentes condiciones como la marginación y la pobreza, y además son un grupo vinculado a la búsqueda de derechos civiles y a la construcción de una narrativa propia. Recién en la década de los sesenta se lograron articular una serie de demandas para exhibir la explotación y la marginación que el pueblo chicano había sufrido durante más de un siglo. Este movimiento agrupaba, como adelantamos, desde estudiantes hasta trabajadores de distintas áreas. Sin embargo, quien logra tener una mayor visibilidad y ser el símbolo del movimiento chicano fue César Chávez (Arellano Aguilar, 1982). Un líder obrero que, incluso en la actualidad, se lleva los papeles protagónicos de la lucha chicana como el símbolo del trabajador explotado. Después de ese movimiento encabezado por César Chávez, que tenía un carácter obrero, han sido las organizaciones 
estudiantiles las que han logrado establecer en la agenda pública de Estados Unidos las demandas por eliminar la marginación y lograr el reconocimiento del grupo.

A partir de la década de los ochenta del siglo pasado las mujeres irrumpen con mayor fuerza en el movimiento chicano, hay quien considera que fue a raíz de la publicación del libro Este puente, mi espalda en 1981 cuando se inicia la lucha política de las mujeres de color, entre ellas las chicanas, pero el activismo previo contradice dicha aseveración (Blackwell, 2006). Lo que sí se puede indicar es que a partir de esa década se plantea una agenda en donde la lucha por la construcción de la narrativa chicana debe partir de reconocer las tensiones internas del grupo, sobre todo con las mujeres, y deshacerse de ciertas tradiciones y prácticas que reafirmaban su sumisión.

\section{Las mujeres en la configuración de una narrativa chicana: el caso de Gloria Anzaldúa}

En el apogeo del movimiento chicano, cuando éste hubo ganado ciertos derechos civiles, surge una de las líneas que más lo cuestionó: se trata de las mujeres, quienes fueron relegadas a un segundo plano, incluso desacreditadas en sus demandas y acusadas de "traicioneras" (Blackwell, 2006). "Las Chicanas, como otras mujeres de color, se vieron forzadas a elegir entre pelear por las causas feministas o pelear los aspectos étnicos y raciales de sus comunidades", sostiene Anzaldúa (2012, p. 9).

Efectivamente una de estas mujeres que luchó por cambiar las condiciones de las chicanas fue Gloria Anzaldúa, quien nació el 26 de septiembre de 1942, perteneciente a una sexta generación de mexicanos que vivían en territorio texano, en un rancho llamado Jesús María que se ubica en el Valle de Río Grande al sur de Texas (Anzaldúa, 2012). 
Texas, un estado con fuertes problemas raciales, le mostró desde su infancia la relación asimétrica ${ }^{26}$ entre los chicanos y los "gringos" en ámbitos laborales y escolares. A ello se suma una visión de inferioridad que asumían los propios chicanos. Estos aspectos, racismo e inferioridad -que a lo largo de su testimonio serán parte central en sus teorizaciones sobre el lenguaje, la sexualidad, el grupo social al que pertenece, la mujer, entre otros- son los pilares que conformaban el discurso ideológico de la supremacía blanca hacia los chicanos. Sin embargo, como bien sostienen Norma Cantú y Aída Hurtado, en la introducción a la edición conmemorativa de Borderlands: "la terrible ironía estaba en que en algunas áreas del Valle cerca del $85 \%$ de los residentes eran descendientes de familias que estaban, como la de Anzaldúa, viviendo en el área antes de que Texas fuera parte de Estados Unidos"27 (2012, p. 5).

Anzaldúa también fue una de las primeras chicanas en manifestar su lesbianismo, un aspecto transgresor en la sociedad chicana en la medida en que se venía discutiendo y disputando cuál era el lugar de la mujer chicana dentro de su entorno social. Recordemos que los primeros movimientos sociales, comandados por hombres en su mayoría, abogaban por un lugar más conservador de la mujer, y cualquiera de ellas que se saliera de ese patrón era considerada como alguien que estaba del lado del "gringo" (Gutiérrez, 1993). La reinterpretación y reconfiguración de su condición de "mujer" permitió evidenciar que hay un grado de opresión y segregación en las mujeres que forman parte de grupos oprimidos. Es decir, la lucha de las mujeres que provienen de sectores subalternos no es la misma del llamado "feminismo hegemónico"28, por lo que se plantea hablar de las mujeres

\footnotetext{
${ }^{26}$ Relación asimétrica que, en muchos casos, condenaba a los chicanos a permanecer en condiciones de pobreza y marginación.

${ }^{27}$ Las citas en inglés tomadas de la crítica académica serán traducidas. "The terrible irony was that in some areas of the Valley at least $85 \%$ of the residents were of Mexican descent whose families had, like Anzaldúa's, resided in the area before Texas was part of the United State".

${ }^{28}$ Bell Hooks crítica que el feminismo institucionalizado terminó por ocultar a un feminismo que buscaba generar conciencia e ir más allá de la lucha por la igualdad de género, pues
} 
desde otro lugar, desde el lugar de los no privilegiados, desde el lugar de los llamados "feminismos de color"29.

Las mujeres de color (las "prietas") se separan en la década de los ochenta del feminismo hegemónico y de las clases medias anglosajonas, pues son evidentes dos cosas: que a las mujeres no nos unen las mismas características, ni las que se vinculan a la discriminación, ni las que definen nuestros intereses y necesidades, ni las que nos describen como mujeres. La segunda tiene que ver con las diversas luchas y discursos que se generan a partir de las filiaciones que sobrepasan aquellas vinculadas al género, es decir de clase, de color y de sexualidad (Belausteguigoitia, 2015, p. 16).

Esos nuevos elementos se verán reflejados a lo largo del libro, pero como idea central se encuentra la conciencia de la "mestiza", una conciencia que rescata símbolos de diversas culturas para dotar de significado al lugar de la mujer en la sociedad chicana.

primero había que "enfrentarse a su sexismo interiorizado". De esta forma, "cuando el movimiento feminista se renueve, reforzará las estrategias que permitan que un movimiento de masas acabe con el sexismo, la explotación y la opresión sexista que subyugan a todo el mundo [...]" (2017, p. 33).

Para Belausteguigoitia el "feminismo de color" desarticuló la idea de un "nosotras" automático sostenido por el feminismo hegemónico dominado por mujeres "blancas” (2015, p. 16).

29"Somos mujeres cuya infancia transcurrió en todo tipo de calles [...]. Somos mujeres de todo tinte de color y grado de clase" (Moraga y Castillo, 1988, p. 9) 
Configuración de una "memoria Nepantla" en Borderlands...

Maestría en Historia y Memoria

Universidad Nacional de la Plata

Anzaldúa a pesar de sus condiciones socioeconómicas logró estudios universitarios. La escuela, ese aparato estatal para educar, ocupó un lugar central en la vida de la autora, pero no para ensalzarla, sino como un espacio en el que ella era testigo de los mecanismos a través de los cuales se pretendía obligar a los chicanos a hablar el inglés y a asimilarse a la cultura "gringa". No sólo no estaba de acuerdo con la pretensión de extirpar el español, también reprueba los métodos a través de los cuales se intentaba conseguir esos resultados, procedimientos que en su mayoría conllevaban la humillación y hasta la violencia física. 


\section{CAPÍTULO II}

\section{BORDERLANDS/LA FRONTERA: THE NEW MESTIZA: LA APUESTA POR UNA "MEMORIA NEPANTLA"}

Borderlands/La Frontera: The New Mestiza se publicó en septiembre de 1987. La aparición de este texto fue recibida con beneplácito por distintos sectores de la sociedad chicana, sobre todo aquellos que ocupaban puestos académicos en las universidades y/o eran activistas de las causas chicanas. Actualmente, Anzaldúa sigue ocupando un "lugar predominante en los debates en torno a la ciudadanía, la identidad y la justicia social" (Belausteguigoitia, 2015, p. 13). Por otra parte, para Cantú y Hurtado la publicación de este libro fue un acto de coraje y una apuesta por la innovación que suele traer la diversidad cultural, "la inclusión de la sexualidad en la producción académica y política, y hablar de una justicia social basada en la inclusión y no en la exclusión"30. Por tal razón, "cuando Borderlands fue publicado generó un tsunami de admiración, de aprecio y, para algunos, un sentido de conexión espiritual; estudiantes y académicos encontraron que era un trabajo inspirador y transformador"31 (Cantú y Hurtado, 2012, p. 6, 9).

En este libro se desarrolla una teoría sobre la frontera, para esto la autora utiliza el lugar geográfico de su nacimiento: el sur de Texas, territorio fronterizo que le permite crear una metáfora de los cruces culturales y psicológicos que están presentes en las sociedades. En este sentido, "borderlands viene a ser, para Anzaldúa, un espacio liminal y psicológico que

\footnotetext{
30 "The inclusion of sexuality in all academic y political production, and a call to social justice based on inclusion rather than exclusion".

31 "When Borderlands was published, it generated a tsunami of admiration, appreciation, and, for some, a real sense of spiritual connection; students and scholars found the work inspiring and transformative".
} 
ella denomina 'nepantla' o 'espacio de en medio"' (Cantú, 2015, p. 55). Así, el libro usa como pretexto esta línea divisoria para hablar de las "otras" fronterías/borderlands, es decir, de los límites del lenguaje, de la identidad, del género, de la raza, entre otros, explorando y analizando qué narrativas han legitimado prácticas que han establecido fronterías que se han naturalizado, dicha revisión deconstruye con la finalidad de lograr una nueva narrativa.

El texto está dividido en dos partes: la primera parte se llama "Atravesando Fronteras/Crossing Borders" y está compuesta por siete capítulos. La segunda parte se llama "Un Agitado Viento/Ehécatl, The Wind" y tiene seis capítulos. Además, en la primera parte domina la prosa, mientras que en la segunda sólo es poesía. Borderlands... es en sí mismo un texto genéricamente híbrido: "la definición de un género (para este escrito) resulta imposible pues navega entre ensayo, relato, ficción, autobiografía y narrativa poética" (Belausteguigoitia, 2015, p. 19). Pero también la hibridez lingüística es un aspecto presente porque a pesar de que la mayor parte del libro está escrito en inglés, la presencia del español es constante e incluso se rescatan muchas palabras consideradas como regionalismos y arcaísmos ${ }^{32}$. En este sentido, se desafían los cánones del uso "correcto" del lenguaje, no sólo porque se emplean varios términos en español que se podrían considerar "mal usados" o fuera de un español vigente, sino porque escribe, como ya se ha señalado, en spanglish, lenguaje considerado incorrecto para algunos de los que defienden la "pureza" del español y del inglés (Betti, 2010 y 2016).

Asimismo, retomar determinados temas desde el punto de vista de la frontería/borderlands tiene un objetivo: mostrar cómo es posible construir la "Nueva Mestiza"33, una propuesta contestataria que busca generar diálogos con "otras" y "otros". Se asume que al ser la cultura chicana el resultado del

\footnotetext{
${ }^{32}$ En especial, se reivindica "un habla rural considerada 'no culta"' (Cantú, 2015, p. 51).

${ }^{33}$ Como se verá, la propuesta de la "Nueva Mestiza" es fundamental en el texto de Anzaldúa, pues a través de esta idea plasma una narrativa de cruces, que interpela a los esencialismos que "justifican" identidades.
} 
cruce de otras culturas mexicanas y estadounidenses, su condición es la hibridez, contrario a las ideas asimilacionistas (en el contexto estadounidense) que abogaban por dar primacía a la cultura "anglo", por ser considerada superior. Anzaldúa no estima que una cultura sea superior a la otra, ni que aporte más que otra, sino que enfoca la configuración de una tercera cultura, la chicana. Ahora bien, decir que retoma las culturas mexicanas y "gringas" como parte fundamental de la identidad chicana conlleva asumir que hay una selección deliberada de estas culturas, de ahí que se hable de la "conciencia de la mestiza". Esto lo confirma José Luis Leal cuando argumenta que los chicanos realizan una elección premeditada de acontecimientos históricos para construir y reconstruir una narrativa propia. En el caso de la historia de México, se suelen retomar periodos prehispánicos, la Independencia de 1810 y la Revolución de 1910 (2000, p. 215).

Si bien estos periodos históricos son importantes y también son retomados en el texto de Anzaldúa, las reinterpretaciones centrales tienen que ver con símbolos femeninos que, en el marco de la narrativa nacional mexicana, responden a los patrones tradicionales de las mujeres. Estos símbolos femeninos son: la Virgen de Guadalupe, la Malinche y la Llorona. Estas reinterpretaciones son centrales porque permiten deconstruir narrativas que encajonan a las mujeres en ideas de sumisión, traición y maldad, como se observará.

Finalmente, a partir de la lectura de Borderlands... se hace una propuesta para estudiar otras formas de memoria a través de lo que se denomina "memoria Nepantla", porque esta noción de "Nepantla", de "lugar intermedio", es la que da a luz a la "Nueva Mestiza", pero ese dar a luz obliga a mirar las herencias culturales y a deconstruirlas. 


\subsection{Borderlborderlands}

Como se ha expuesto, en el prefacio a la primera edición de su libro, Anzaldúa realiza una distinción conceptual fundamental sobre lo que es border y borderlands. Estos conceptos marcan un eje dentro de la estructura del libro al ser los términos con los que trabaja la noción de límite y de transgresión a lo largo de su texto. De la misma forma, la autora considera que un lugar de frontera genera un tercer espacio entre culturas y sistemas sociales, donde la hibridez se manifiesta con mayor intensidad (Cantú y Hurtado, 2012, p. 6). Para dar cuenta de ese fenómeno en donde viven y conviven de manera simultánea sociedades que pueden concebirse como excluyentes o contradictorias, introduce el término "Nepantla", que es una palabra de origen náhuatl y que significa "estar en un espacio intermedio". Anzaldúa se apropia de este término para argumentar la capacidad de transformación física, espiritual y material. En este sentido "Nepantla" representa un espacio liminal donde esas transformaciones pueden suceder (Keating, 2006, p. 8).

De esta forma argumenta que "the actual physical borderland that I'm dealing with in this book is the Texas-U.S Southwest/Mexican border. The psychological borderlands, the sexual borderlands and the spiritual borderlands are not particular to the Southwest". Anzaldúa se considera una mujer de frontería, no sólo por haber nacido en un territorio fronterizo, sino porque creció entre dos culturas "the Mexican (with a heavy Indian influence) and the Anglo (as a member of a colonized people in our own territory)"34 (1987). Estas herencias culturales son las que configuran la narrativa de la autora, aunque hace un énfasis especial en el legado mexicano por tratarse de un patrimonio que ha determinado a los chicanos en varios sentidos que van desde el lugar que ocupan en los Estados Unidos, algunas prácticas y costumbres, hasta símbolos culturales que han influido en concepciones sobre la mujer.

${ }^{34} \mathrm{Ambas}$ notas forman parte del prefacio. 


\section{Apuntes generales sobre Borderlands...}

Abordar el libro de Gloria Anzaldúa resulta una tarea compleja que se traduce en una diversidad de estilos en la escritura que lo vuelven un texto híbrido, ya que no se puede catalogar en un sólo género literario. Utiliza distintas formas de escribir y a través de esas formas genera lo que ella considera el testimonio sobre su vida y su comunidad.

Para poder desentrañar y realizar un análisis reflexivo sobre cómo Anzaldúa defiende, rescata e intenta preservar símbolos, mitos y creencias en torno a una visión de lo humano más incluyente y tolerante es pertinente enfocarse en dos pilares claramente fijados en el texto (que no son los únicos, pero sí son retomados constantemente y en esa medida se pueden calificar como primordiales). Dichos temas son: la lengua y los símbolos reinterpretados como parte de la herencia cultural. Cada uno de estos puntos daría por sí mismo un análisis prolijo, pero para vincularlos con los estudios sobre la memoria resulta permitente analizar la configuración de la "memoria Nepantla".

\section{El testimonio en Borderlands...}

Para Belausteguigoitia, la escritura de Anzaldúa es de frontera (que corresponde a la frontería de Abril Trigo) y, en ese sentido, trabaja lo académico, lo testimonial y lo autobiográfico (2015, p. 26). Aunque, como argumenta Cecilia Núñez, predomina el tono testimonial del texto (2015, p. 76). Las reflexiones académicas las inserta ya sea para realizar una crítica al pensamiento racional occidental, o para resaltar ideas que le ayudan a construir su noción de "Nueva Mestiza". Así, desde el punto de vista testimonial, en Borderlands... se trabaja una escritura de triple identidad en varios sentidos: relación entre lo mexicano, lo "gringo" y lo chicano; relación 
entre el español, el inglés y el spanglish; relación entre el "yo" (Anzaldúa), "nosotros" y los "otros".

En la relación "yo", "nosotros" y "otros" se encuentran referencias permanentes a la memoria colectiva ("nosotros") y a la memoria individual ("yo"); en este ir y venir de lo colectivo a lo individual hay un cuestionamiento constante hacia la narrativa heredada, porque sólo reflejaba lo que pensaban los "anglos" ("otros") acerca de los chicanos para seguir justificando el lugar de opresión que ocupaban.

Como también indica Belausteguigoitia, este ejercicio testimonial de la autora se convierte en un eje pedagógico de suma importancia, ya que "conjuga una enorme complejidad con una seducción y urgencia a la acción y al cambio, no sólo al activismo sociopolítico, sino al cambio personal e íntimo" (2015, p. 25).

El testimonio de Anzaldúa arranca cuando plantea que la frontera entre México y Estados Unidos es una "herida abierta" (1987, p. 3), ya que con esa metáfora no sólo se aborda el presente desigual en la frontera, sino que, precisamente, esa es una herida que no se ha cerrado desde mediados del siglo XIX, cuando parte de México pasó a ser de los Estados Unidos. En esta "herida abierta [...] se vuelve complicado existir y de la cual es sumamente doloroso hablar" (Núñez, 2015, p. 77). Así, la autora genera un testimonio comunitario, documentado por lo que ella fue escuchando a lo largo de su vida sobre el drama que implicó ser extranjero en tierra propia, sin ningún tipo de mediación por parte de algún gobierno para que se cumplieran los acuerdos firmados en el Tratado de Guadalupe-Hidalgo, quedando a la deriva y desprotegidos en muchos sentidos. En dicho tratado, firmado en 1848, se estipulaba que los mexicanos que vivían en los territorios apropiados podían permanecer ahí, pero en el lapso de un año tenían que definir si querían tener la ciudadanía mexicana o la estadounidense, sino se tomaba o se hacía una declaración manifiesta al respecto, entonces se asumía que aceptaban la ciudadanía estadounidense (Soberanes y Vega, 1998, p. 24). Lo anterior era lo que determinaba el 
Artículo IX del tratado, sin embargo poco tiempo después este artículo fue modificado y se estableció que quienes tuvieran la ciudadanía mexicana, la ciudadanía estadounidense les sería dada cuando el gobierno norteamericano lo considerara conveniente (Soberanes y Vega, 1998), lo cual hizo que la situación de los habitantes de estos territorios, pertenecientes ya a Estados Unidos, fuese más complicada, porque la desprotección de las leyes norteamericanas y la no aplicación de lo que se había firmado en el tratado permitieron una serie de abusos y vejaciones. Abusos que Anzaldúa denuncia en su texto y que no sólo remiten a las condiciones laborales, donde regularmente eran explotados, sino que hacen referencia a cómo su familia poco a poco fue perdiendo las propiedades que tenían en los Estados Unidos hasta quedar sin nada. La escritora chicana narra cómo después de una larga sequía que había asolado las tierras del Sur de Texas, donde la familia de la autora tenía posesiones territoriales, "a smart gabacho lawyer took the land away mamá hadn't paid taxes. No hablaba inglés, she didn't know how to ask for time to raise the money. My father's mother, Mama Locha, also lost her terreno" (1987, p. 8). Anzaldúa va describiendo la serie de engaños y arrebatos de tierra a través de los cuales se fue relegando a los chicanos a muy pocas opciones de vida. Esas pocas opciones se redujeron en muchos casos al trabajo en el campo y en las casas de los blancos estadounidenses.

My sister, mother and I cleaned, weighed and packaged. (For years afterwards I couldn't stomach the sight of an egg.) I remember my mother attending some of the meetings sponsored by well-meaning whites from Rio Farms. They talked about good nutrition, health, and held huge barbeques (p. 9). 
De esta forma, la autora a través de su experiencia de vida, de su testimonio, da cuenta de lo que ha sido, es y quiere que sea el pueblo chicano. Se trata de un texto que deconstruye algunos de los elementos que se han querido asumir como inherentes a los chicanos y que han servido para someter y humillar a su comunidad. En conclusión, la narración gira en torno a "los atropellos y las prohibiciones que pesan sobre sí misma y sobre los chicanos que han creado esta nueva identidad a partir del exilio" (Núñez, 2015, p. 77).

\subsection{El spanglish y las herencias lingüísticas}

Una de las características principales de Borderlands...es su hibridez lingüística. El texto se escribe en español (distintas variantes de este idioma), náhuatl e inglés, aunque dominan el inglés y el español. A lo largo de la escritura existe una alternancia de códigos entre las últimas lenguas mencionadas, por lo que se inscribe en lo que se denomina la teoría del Code-Switching (Lakhtikova, 2017; Lipski, 2003; Poplack, 1980). En este sentido, la lengua es uno de los pilares del texto, en primer lugar, porque hay en él una denuncia de cómo el spanglish ha sido mal visto y se ha intentado reprimir en distintos ámbitos. En segundo lugar, porque es a través de la lengua que se refleja cómo ésta no es un aspecto que se pueda delimitar, no se puede establecer cuáles son las fronteras de un idioma, ya que los términos son apropiados, reapropiados, interpretados y reinterpretados por las sociedades. Desde esta perspectiva, el spanglish se justificaría por su uso, porque forma parte de una forma de vida y aunque se intenten establecer marcos reguladores y puristas (academias del lenguaje), su uso los trasciende: se está frente a "una manera de vivir, marcada de hibridación, de identidad, de multiculturalismo, que en los Estados Unidos representaría a muchos latinos que viven entre estas dos realidades" (Betti, 2010, p. 41). A pesar de esto, Lipski menciona cómo el spanglish representa para algunos 
críticos una "enfermedad lingüística de consecuencias mortales para la vitalidad de la lengua española, no sólo en los Estados Unidos sino a través del mundo" (2003, p. 235). Se trata de una lengua "inapropiada" para quienes defienden tanto al español como al inglés en su sentido "puro". Silvia Betti también recalca que "a menudo se ha escrito y se escribe que el spanglish es fruto de la ignorancia, de los que no tienen cultura o recursos suficientes para aprender bien el inglés $y$, en algunos casos, incluso el mismo español” (2010, p. 33).

Anzaldúa vivió en carne propia las críticas que se han expuesto sobre el spanglish. Así, muestra cómo por distintos medios los "gringos" intentaban "cortar la lengua que habla español". Pero esos medios no sólo responden a los sectores dominantes de los Estados Unidos, sino que la misma madre de la autora le recriminaba el hecho de que hablara inglés con un tono mexicanizado: "Pa' hallar buen trabajo tienes que saber hablar el inglés bien. Qué vale toda tu educación si todavía hablas inglés con un 'accent', my mother would say, mortified that I spoke English like a Mexican" (1987, p. 54). Existía un prejuicio hacia el spanglish, ya que era visto como un impedimento para ingresar a la sociedad estadounidense blanca.

Defender al spanglish ha representado una de las principales batallas libradas por los chicanos en los Estados Unidos: "hablar y escribir spanglish ha sido una postura de rebeldía ante el entorno anglosajón dominante [...] y les confiere identidad y unidad como nueva cultura híbrida" (Prieto, 2004). Anzaldúa indica que en la defensa del spanglish se han enfrentado a una serie de obstáculos establecidos, sobre todo, por sectores poseedores de la potestad para indicar cuál es la lengua "correcta" (1987, p. 54). En este sentido, el spanglish al ser una lengua que retoma términos del inglés y del español se enfrentaba con una doble deslegitimidad, ya que, por un lado, están quienes sostienen que el español se desvirtúa por el modo que lo recupera el spanglish; por otro lado, están quienes defienden la pureza del inglés, por lo que es una amenaza el uso que hacen de esta lengua los hispanohablantes (Betti, 2016). En suma: "Chicano Spanish is considered by 
the purist and most Latinos deficient, a mutilation of Spanish" (Anzaldúa, 1987, p. 55).

El spanglish "is a border tongue", una lengua que se desarrolló a partir de la mezcla entre distintas culturas, por lo cual "Chicano Spanish is not incorrect, it is a living language" (p. 55). Esta lengua explica un fenómeno que se remonta al momento en que comienza un tránsito bilingüe producto de la firma del Tratado de Guadalupe-Hidalgo, pero el término "es acuñado por Salvador Tió en 1948" y con ello "da una idea precisa de la conducta verbal que caracteriza a muchas de las comunidades de origen hispano que residen en Estados Unidos" (Betti, 2010, p. 32).

Anzaldúa explica que los chicanos hablan español estando inmersos en una sociedad donde el inglés es la legua hegemónica, pero ellos no son anglos. Se nutren de ambas lenguas, aunque también tienen influencias de otras. Ante este panorama: "what recourse is left to them but create their own language?" (1987, p. 55). El spanglish surgió del cruce de culturas y también de una necesidad de poder generar canales de comunicación a través de los cuales sea posible transmitir saberes entre el grupo: "El spanglish es el producto del mestizaje y de la migración, y a su vez frontera entre dos lenguas, dos culturas, dos sensibilidades y dos modos de ver y afrontar la vida" (Betti, 2016, p. 69).

Como bien informa Betti (2010), el spanglish no es exclusivo de los chicanos (a pesar de que su surgimiento es asociado con el momento en que gran parte del territorio mexicano pasó a ser de los Estados Unidos), pues se encuentran variantes de esta lengua en los puertorriqueños, los cubanos, entre otros, derivadas de sus propias lenguas. Teniendo en cuenta esto, resulta conveniente observar cuáles son las vertientes lingüísticas que se articulan en el spanglish de los chicanos. Anzaldúa identifica el inglés estándar, que sería el inglés promedio, aceptado por las academias, que habla la sociedad estadounidense, el working class and slang English, el Standar Spanish, el Standard Mexican Spanish, el North 
Configuración de una "memoria Nepantla" en Borderlands...

Maestría en Historia y Memoria

Universidad Nacional de la Plata

Mexican Spanish dialect, el Chicano Spanish (Texas, New Mexico, Arizona and California have regional variations), el Tex Mex y el Pachuco (p. 55).

My "home" tongues are the languages I speak with my sister and brothers, with my friends. They are the last five listed, with 6 and 7 being closest to my heart. From school, the media and job situations, I've picked up standard and working class English. From Mama grande Locha and from reading Spanish and Mexican literature, I've picked up standard Spanish and Standard Mexican Spanish. From los recién llegados, Mexican immigrants, and braceros, I learned the North Mexican dialect. With Mexicans I'll try to speak either Standard Mexican Spanish or the North Mexican dialect. From my parents and Chicanos living in the Valley, I picked up Chicano Texas Spanish, and I speak it with my mom, younger brother (who married a Mexican and who rarely mixed Spanish with English), aunts and older relatives. (p. 56)

Anzaldúa indica que con las chicanas de Arizona y Texas puede hablar un poco de español; pero con las chicanas de California habla casi siempre en inglés. De los chicos de su misma edad tomó el "pachuco", la lengua de los Zoot Suiter- "un estilo de vestir que usaban los jóvenes latinos y afroamericanos en la América de la Gran Depresión y que provenía de la tradición del jazz" (Mejía, 2016, p. 474). El "pachuco" es una lengua de rebelión contra el español estándar y el inglés estándar, que pocos pueden entender por la cantidad de términos nuevos y distorsionados que integra. Sin embargo, algunos conceptos ya se han difundido y hoy forman parte del 
español mexicano, como por ejemplo: "ruca" que significa muchacha o mujer, "vato" que significa muchacho, "simón" que significa sí, entre otros.

Otro aspecto que diferencia el spanglish del español es que en aquel idioma se pegan dos vocales adyacentes como cohete/cuete, y también se quitan consonantes de ciertas palabras como lado/lao. Algunos texanos del sur pronuncian la f como si fuera una j, jue por fue. Además, son utilizados arcaísmos como "haiga", "truje", "semos ansina", "naiden", y anglicismos como "parkiar" por park, "watchar" por watch, entre otros (p. 56, 57).

Finalmente, el spanglish sirve de vehículo de comunicación de un universo propio a pesar de que no hay consenso respecto a su legitimidad en un sentido lingüístico: "El spanglish considerado expresión polimorfa, pseudo lengua, lengua fronteriza, jerga, comportamiento verbal híbrido, código 'bastardo', 'aberración', 'mezcla sin importancia', juego, es el producto de la migración, pero también es vehículo de sentimientos y nostalgias [...]" (Betti, 2016, p. 73). Anzaldúa insiste en que cuando se habla mal de esta lengua se la hiere. "Ethnic identity is twin skin to linguistic identity-I am my language". Aunque asume que la lucha por el reconocimiento tendrá que seguir, se niega a recurrir solamente al español o al inglés para comunicarse como una forma de "acomodarse" a la lengua de los demás, y solicita que se haga un esfuerzo por entender o hablar el spanglish, de lo contrario: "my tongue will be illegitimate" (p. 59).

\section{El uso del Code-Switching en Borderlands/La Frontera...}

El Spanglish es una lengua de frontería y como tal es el ejemplo de la tensión que se genera cuando una lengua trasciende los límites impuestos a la misma para considerarla correcta. Anzaldúa profundiza sobre la importancia de la lengua en una sociedad de frontería y cómo esa lengua tiene un papel fundamental para la construcción de una narrativa chicana. 
De esta forma, se puede observar que hay un acercamiento academicista hacia el spanglish, un acercamiento que intenta legitimar dicho lenguaje más allá de los usos cotidianos dentro de la comunidad chicana. De ahí que la autora se valga de la teoría del cambio de código (Code-Switching) para llevar el debate sobre el spanglish más allá del dominio comunitario, precisamente para poder trascender los límites que como grupo se han generado.

Para Anzaldúa no sólo es importante que los chicanos se sientan orgullosos de su lengua, también le interesa que el spanglish deje ese lugar de bastardía que se le ha dado en Estados Unidos, por eso hace énfasis en entablar diálogos con los "anglos" a fin de traspasar límites y que su lengua pueda ser más conocida y reconocida.

¿Pero en qué consiste esta teoría del Code-Switching? El CodeSwitching o la alternancia de códigos consiste en el uso de uno o varios idiomas en la escritura de un texto: "Una de las particularidades de la alternancia de códigos es que la sintaxis se desarrolla principalmente a partir de una de las lenguas en contacto incorporando al discurso elementos léxicos y culturales de otra lengua" (Spoturno, 2005, p. 2). En el caso de la escritura chicana suele predominar el inglés sobre el español. Por su parte, los escritores lo utilizan ya que intentan reflejar el habla cotidiana de su comunidad, utilizando los términos que en determinadas situaciones son más significativos (Martin, 2005, p. 403). Además, es una forma de documentar ese encuentro de dos lenguas, el inicio del hibridismo que da origen a una tercera lengua y que permite a los chicanos comenzar a forjar un espacio de protesta desde el terreno lingüístico.

En este caso, se ha relacionado el spanglish con los chicanos, pero, como se ha mencionado, se debe tener en cuenta que existen varios spanglish y que cada uno de ellos tiene características que impiden homogeneizar esta lengua. Se reconoce que los primeros indicios de esta lengua se remontan a fines del siglo XIX, cuando México pierde parte de su territorio, por lo cual la primera manifestación del spanglish es chicana, sin 
que esto signifique que sea más importante que el resto (Fernández, 2004; Betti, 2010).

El uso de términos o frases en español por parte de escritores y escritoras chicanos/as en sus textos responde a la necesidad de contar con palabras que tengan un mayor impacto en el habla de la comunidad, ya que no es lo mismo decir fuck you que decir "chíngate", la carga lingüística y cultural de estas palabras las coloca en una dimensión simbólica distinta dentro de la comunidad chicana: "El recurso a otra lengua plantea una alteridad, una marca de heterogeneidad, respecto del propio discurso. Entendemos que en la literatura chicana la alternancia de códigos tiene el estatuto de rasgo distintivo ya que constituye un acto de identidad" (Spoturno, 2005, p. 1, 2).

John Lipski, lingüista y uno de los principales teóricos del CodeSwitching, argumenta que una de las principales críticas que hacían quienes no aceptaban esta alternancia de códigos, era que existía una confusión mental, una incapacidad para separar dos lenguas, con esto se ponía en entredicho el bilingüismo de las personas. Sin embargo, estudios posteriores demostraron, según Lipski, que se requiere ser una persona muy hábil para hacer un uso correcto de varias lenguas. Con el paso de los años, también se ha observado cómo se pueden encontrar regularidades gramaticales en los textos donde se aplica el Code-Switching que permiten realizar un estudio sobre un idioma que se ha abierto poco a poco un espacio en los Estados Unidos (1985).

Para Lipski, se pueden ubicar dos tipos de Code-Switching: the intersentential (intersentencial) y the intrasentential (intrasentencial). El primero es usado por aquellas personas que aún no dominan del todo un segundo idioma o no saben cómo hacer un desplazamiento de términos dentro de una sentencia, por eso suelen cambiar una frase o término sólo al final de dicha sentencia. Por su parte, en el segundo uso "el cambio 
impresiona al observador por sus suaves transiciones entre el lenguaje" 35 (1985, p. 3). Un ejemplo de esa sutileza en el manejo de los términos se encuentra en Anzaldúa, pues en su escrito se observa una alternancia en los códigos que no descontextualiza la narración, sino que, precisamente, pone mayor énfasis en lo que se pretende exponer.

In the fields, la migra. My aunt saying, "No corran, don't run. They'll think you're del otro lao." In the confusion, Pedro ran, terrified of being caught. He couldn't speak English, couldn't tell them he was fifth generation American. Sin papeles -he did not carry his birth certificate to work in the fields. La migratook him away while we watched. Se lo llevaron. He tried to smile when he looked back at us, to rise his fist. But I saw the shame pushing his head down, I was the terrible weight of shame hunch his shoulders. They deported him to Guadalajara by plane. The furthest he'd ever been to Mexico was Reynosa, a small border town opposite Hidalgo, Texas, not far from McAllen. Pedro walked all the way to the Valley. Se lo llevaron sin un centavo al pobre. Se vino andando desde Guadalajara (1987, p. $4)$.

En este párrafo también se pueden observar algunas de las formas que Lipski menciona como usos comunes del Code-Switching. Por ejemplo, el autor indica que con frecuencia un mismo término o frase se pone primero en una lengua y luego se traslada a la segunda que se está utilizando. En la cita anterior vemos cómo utiliza este recurso: "No corran, don't run". Esta

35 "Shifting immediately impresses the observer by its smooth transitions between the language". 
forma de hacer énfasis en una frase es un uso recurrente en el texto de Anzaldúa y se puede encontrar en los siguientes ejemplos:

- Nuestra abogada siempre serás/ Our mediatrix you will always be (p. 30).

- En boca cerrada no entran moscas/ Flies don't enter a closed mouth (p. 54).

El cambio de código es también un recurso de la autora para que un público más amplio tenga acceso a su lectura.

Otras formas gramaticales que suelen estar presentes en los textos escritos con alternancia de códigos son las que utilizan el sustantivo en inglés y el verbo en español, o viceversa, como por ejemplo:

- The U.S, Mexican border es una herida abierta. (p. 3)

- Los atravesados live here. (p. 3)

- La gorra, el rebozo, la mantilla are symbols of my culture's "protection" of women. (p. 17)

De esta forma, Lipski concluye que la alternancia de códigos en la escritura no es una confusión en el uso de los términos, al contrario, la utilización de estos tiene que ver con fines literarios específicos que permiten resaltar aspectos deseados (1985, p. 73). Así pues, Anzaldúa en el prefacio de su libro indica que: 
The switching "code" in this book from English to Castillian Spanish to the North Mexican dialect to TexMex to a sprinkling of Nahuatl to a mixture of all these, reflects my language, a new language -the language of the borderlands [...]Presently this infant language, this bastard language, Chicano Spanglish, is not approved by any society.

La posibilidad de alternar diversas lenguas es, entonces, para Anzaldúa una fuente de riqueza. En este sentido, "[...] muestra cómo el code-switching no es sólo un cambio de un lenguaje a otro como si fuera un discurso continuo, sino que se basa en los recursos de ambos lenguajes para expresar pensamientos e imágenes coherentes" ${ }^{36}$ (Martin, 2005, p. 406). El spanglish, además de entablar un diálogo no sólo con la sociedad chicana, le permite a Anzaldúa crear un puente entre las culturas mexicana y estadounidense, dos sociedades a través de las cuales busca comprender su herencia.

Desde el Code-Switching también va a reflexionar sobre el uso de los pronombres como la primera y la tercera persona del plural, ya que, por ejemplo, el "we" en inglés es un pronombre neutro que se utiliza para lo masculino y lo femenino, por lo que la autora considera que este pronombre en inglés no permite hacer énfasis en la fortaleza del "nosotras" como colectivo.

The first time I heard two women, a Puerto Rican and a Cuban, say the word "nosotras", I was shocked. I had

\footnotetext{
${ }^{36}$ [...] shows how code-switching is not so much a change from one language to the other as it is a continuous discourse, drawing upon the resources of both languages to Express coherent thoughts and images".
} 
Configuración de una "memoria Nepantla" en Borderlands...

Maestría en Historia y Memoria

Universidad Nacional de la Plata

not know the word existed. Chicanas use nosotros whether we're male or female. We are robbed of our female being by the masculine plural. Language is a male discourse (1987, p. 54).

Como expone Tara Lockhart (2007), esta reflexión plantea la relegación cultural de las mujeres por medio del lenguaje. Asimismo, en una entrevista, Anzaldúa argumenta que este uso del "nosotras" tiene un doble sentido, ya que el "nos" hace referencia al we y el "otras" hace referencia a otras mujeres, a las que dentro de un discurso colonial no tienen voz, las que son relegadas por su color de piel y por su condición económica (Ikas, 2012, p. 281).

\section{La "lengua rebelde" en el marco de una pedagogía del "control"}

En el capítulo cinco, "How to tame a wild tongue", Anzaldúa describe una visita al dentista. A partir de esta narración se genera una metáfora sobre la "lengua rebelde": el dentista procura controlar su lengua, domeñarla, y se exaspera ante sus excesos y el flujo de la sangre ("We're going to have to do something about your tongue"), con cierto grado de enojo y dice que "I've never see as strong or as stubborn" (1985, p. 53). La autora se pregunta ¿cómo se domina una "lengua salvaje"? y es desde esta pregunta que se narran una serie de situaciones en las que a los chicanos se les corregía por hablar español o por hablar mal el inglés (1987).

Un aspecto que sobresale en este capítulo es el papel jugado por la escuela para intentar domesticar la lengua de quienes no hablaban inglés y para remarcar que un "buen" manejo de este idioma significaba una posibilidad de acceso a la sociedad "gringa". En este sentido, Virginia 
Crisco, en una investigación que realizó sobre los usos que hacen de las lenguas los estudiantes que proceden de una cultura lingüística distinta a la del inglés en los Estados Unidos (como los hijos de padres mexicanos o nacidos en México), encontró que en "las instituciones académicas se espera que los estudiantes aprendan el inglés para volverse parte de la cultura dominante americana" (2004, p. 51). Sin embargo, muchos de los estudiantes entran en conflicto, pues por un lado reciben la presión de los padres para que no olviden su herencia cultural, pero por otro lado, se enfrentan a un discurso que exalta la asimilación lingüística como camino necesario para ser reconocido en la sociedad "gringa". En el caso de Anzaldúa la presión para que aprendiera un inglés "correcto" y sin acento, no sólo provenía de los ámbitos institucionales, sino que también su madre la controlaba para que hablara bien el inglés, pues esa era la "garantía" para poder tener un ascenso social $(1987$, p. 53).

Paulo Freire, en Pedagogía del Oprimido (2005), brinda herramientas para abordar rutinas escolares que justifican una relación jerárquica entre estudiantes y docentes. En este sentido, la escuela es uno de los espacios sociales que se encarga de asegurar que los estudiantes sean receptores de las ideas consideradas como "legítimas" sobre la cultura en que se está inmerso. Este es un lugar clave para propagar ideas y educar a las personas respecto a ciertos paradigmas rectores de una sociedad. Además, la escuela es el lugar perfecto para que los individuos, con orígenes distintos, asimilen la cultura en que están insertos. Así, la tarea de la escuela, planteada desde la relación opresor-oprimido, consiste en seguir respaldando los presupuestos que fundamentan a las naciones.

Para Freire, las relaciones entre educador y educandos representan una lógica de dominación entre el opresor y el oprimido, ya que los estudiantes son la parte pasiva de esa relación, los "ignorantes" que acuden a aprender, los que sólo deben escuchar las disertaciones del docente, quien se encarga de resguardar el orden preestablecido socialmente, es decir, repite y transmite los mitos que dan "sentido" y justifican un "orden" social. La 
escuela se vuelve un espacio en el que asimilación se impone a los "oprimidos", pues "para conquistar ciertas satisfacciones deben adaptarse a los preceptos que se establecen de forma vertical" $(2005$, p. 77,202$)$.

En la literatura hay muchos ejemplos de este funcionamiento de la escuela, en donde se muestra el papel central del docente para concretar objetivos cuyo fin es aleccionar a los alumnos a una determinada forma de pensar y de ver el mundo. También hay ejemplos donde los educandos se rebelan ante lo que se espera de ellos. A continuación se presentan dos textos literarios que ejemplifican esta relación "opresor-oprimido" en el ámbito escolar.

El cuento "Paco Yunque" (1984), de César Vallejo, se centra en el espacio del aula escolar como escenario de reafirmación del sistema de dominación: el alumno que posee riqueza es superior y el docente ${ }^{37}$ se ve subyugado ante su dinero y justifica sus abusos.

"Tizoc" (2015), poema del escritor mexicano Yolotl Senemi, refleja una situación contraria a la de "Paco Yunque". En el cuento de Vallejo hay una sumisión tanto del estudiante Paco como del docente a un sector económico empoderado, y una aceptación del orden establecido, mostrando cómo la escuela puede funcionar como un aparato de reproducción de ese orden. EI poema, en cambio, está vinculado con la "lengua rebelde" de Anzaldúa, puesto que allí el alumno no se calla ni se somete silencioso a la autoridad, tal como la narrativa nacional impone.

\section{[...] Tizoc, deja de estar soñando en clases deja de soñar que eso no nos pertenece,}

\footnotetext{
${ }^{37}$ Durante sus clases, el profesor deja en claro la preferencia por el niño rico, Humberto Grieve, quien tiene una relación de dominación hacia otro de los niños, Paco Yunque, quien es hijo de unos empleados de la familia Grieve, y por eso, en varias ocasiones, Humberto dice que Paco Yunque es su muchacho.
} 
Configuración de una "memoria Nepantla" en Borderlands...

Maestría en Historia y Memoria

Universidad Nacional de la Plata

en un instante vendrá el presidente a saludarte, párate correctamente y se muy amable.

-Buenas tardes, Tizoc.

¿A qué tarde se refiere señor presidente?

¿Quizá de aquella tarde en que se mató a tanta gente inocente?

-No, Tizoc, yo me desvelo por la seguridad de nuestro país.

¿Y cuándo viene a México a velar por el nuestro?

-Tizoc, estás reprobado.

Que repruebe el mar de mi reproche

que mis huaraches ya no tienen correa para más soporte, ¿qué acaso el sol pertenece a una cierta clase de gente?

-Salte del salón, Tizoc.

Salgo porque solo afuera respiro el último suspiro de libertad, porque sentado y en un salón nunca me enseñarán qué es amar.

-Tizoc, no hables así.

¿Desde cuándo ponen candado en la boca del humano?

¿Desde cuándo se deja de soñar si de eso está hecha esta tierra?

-Estás perdido, Tizoc.

Desde que tengo memoria he perdido respeto y ganado el insulto.

-Así son las cosas, Tizoc.

¿Y los que no somos así y nos negamos, en dónde quedamos?

[...]

(Senemi, 2015, p. 12, 13) 
En Tizoc el docente es el "moldeador", el "amasador" del estudiante, pero "fracasa" al no conseguir el comportamiento adecuado ante una autoridad como el presidente, a quien exhibe por su ausencia ante las problemáticas del país. Tizoc es un nombre náhuatl que significa "el que hace sacrificio", y en el poema representa a los sectores indígenas que han sido marginados, que han sido silenciados, de ahí que el presidente también es alguien que ha gobernado para otro país, no para el México de Tizoc. Este poema guarda una estrecha relación con Anzaldúa por la rebeldía manifiesta en no permanecer callado, en desatar su lengua ante los intentos de control.

Para Anzaldúa resulta central la experiencia como alumna chicana en los primeros años de su educación y después en los años de la universidad. En ambos momentos la autora se enfrenta al mandato de no hablar el español, ni inglés con acento mexicano, no sólo porque no era la lengua "correcta" en los Estados Unidos, sino porque para ser una "verdadera" estadounidense tenía que hablar el inglés. La autora recuerda que su maestro en los primeros años escolares la reprimía cuando intentaba corregir la pronunciación de su nombre y le decía: "If you want to be American, speak 'American.' If you don't like it, go back to Mexico where you belong" (p. 53). Esta escena refleja varias cuestiones: una de ellas es la labor correctiva del profesor hacia el estudiante indicándole qué lengua tiene que hablar y además se remarca la impertinencia de que el alumno "corrija" al docente. Otro aspecto resaltado es el desprecio del docente hacia su alumna de origen mexicano, a quien no le reconoce su pertenencia a Estados Unidos. Por ello la escuela, en la experiencia de la autora, tampoco era el lugar de inclusión social de los chicanos, al contrario, eran exhibidos y humillados sólo por el hecho de no hablar inglés, pronunciarlo mal o usar frases en español.

Hay además otro aspecto relevante: los "gringos" asumían que quien hablaba español era mexicano. Ello se debe a la zona en la que se 
desarrolla la escena, sur de Texas, pero esta también refleja una concepción homogénea sobre los hablantes del español.

La autora vivió otra situación conflictiva durante sus años de universidad al aludir que "At Pan American University, I, and all Chicanos students were required to take two speech classes. Their purpose: to get rid of our accents" (p. 54). No sólo se trataba de que hablaran el inglés, sino de que lo pronunciaran bien, haciendo una especie de "blanqueamiento" de la lengua. La intención era ocultar, en la medida de lo posible, las referencias culturales consideradas "inferiores", apelando a una idea anglosajona de superioridad que justificaba la imposición de una lengua sobre otra: "El Anglo con cara de inocente nos arrancó la lengua. Wild tongues can't be tamed, they can only be cut out" (p. 54). Pero este arranque de la lengua tiene repercusiones en otros ámbitos, porque no se trata sólo de la exigencia de asimilarse a una cultura -aunque este aspecto de la asimilación también es cuestionable, porque los chicanos son considerados seres inferiores, humanos que están por debajo de los estándares de una cultura que se considera superior en todos los sentidos-, también se intenta sostener la versión histórica de los beneficios de la apropiación que hizo Estados Unidos de esos territorios. Versión que entra en conflicto con el testimonio de Anzaldúa y que se refleja en distintos momentos, pero con mayor fuerza cuando se encuentra frente al "opresor".

Jacques Ranciére en el Maestro Ignorante plantea el problema de la relación alumno/maestro en su concepción tradicional y argumenta que en el fondo de dicho nexo suele estar presente la superioridad del maestro y su autoridad para marcar las directrices a los alumnos y de esta forma moldearlos a determinadas perspectivas. Por tanto, esos docentes que reprendían a Anzaldúa por su acento y por hablar español "cumplían" con su rol dentro de un sistema educativo. De esta forma, así como se establece que la escuela es un espacio para generar conocimiento, también puede ser un lugar que garantiza la continuación de un orden social: "La misma naturaleza que abre a todos los espíritus la carrera de las ciencias 
quiere un orden social donde las clases estén separadas y donde los individuos se conformen con el estado social que les ha sido destinado" (Ranciére, 2002, p. 23).

La creencia sobre la inferioridad de los chicanos no sólo era gestada en el interior del grupo, sino que formaba parte de la narrativa que los fue permeando hasta interiorizar esa inferioridad y asumir lo que de ellos se decía. Como expresa Ranciére "lo que atonta al pueblo no es la falta de la instrucción sino la creencia en la inferioridad de su inteligencia" (2002, p. 25).

\section{Romper el silencio y ser una "hija de la chingada"}

La alternancia de códigos, para introducir términos o frases en español y náhuatl principalmente (Amezcua, 2016, p. 11), no es sólo para mostrar la capacidad de dominio de distintas lenguas que tiene Anzaldúa, sino, como sostiene Norma Cantú, para desafiar al lector. En Borderlands..., a través del spanglish, también se recuperan y reinterpretan herencias culturales. Plasma en su escritura que los chicanos son el resultado de cruces y reivindica términos considerados como manifestación del México rural o simplemente usos "arcaicos" del español (2015, p. 49, 56), así como otros en náhuatl poco usados en español, tal es el caso de Nepantla, término que se vuelve central en el texto para reflexionar sobre "borderlands (Anzaldúa, 1987), "fronterías" (Trigo, 1997) e "in-between" (Bhabha, 2002). En este sentido, "el español chicano reivindicado por la autora hunde sus raíces en ese espacio intermedio y participa de esa misma ambigüedad" (Amezcua, 2016, p. 10), lo mismo sucede con el inglés, al hacer un uso que no es considerado el "adecuado".

Ya se ha mencionado que las mujeres estaban constreñidas a roles tradicionales, lo que les impedía tener un papel activo en las luchas sociales 
libradas por los chicanos, principalmente, en la segunda mitad del siglo XX. Ese bloqueo a las mujeres también implicó su silencio en la narrativa chicana, en donde los "protagonistas" de las luchas eran hombres: "La práctica de contar la historia del movimiento chicano frecuentemente no sólo borra la participación que tuvieron las mujeres desde un comienzo, sino que genera una hegemonía masculina dentro de esas narrativas" (Blackwell, 2008, p. 351). Maylei Blackwell sostiene que las mujeres chicanas lucharon a la par de los hombres en el movimiento de los años sesenta, aunque fueron invisibilidades y no se les reconoció su lucha. En este sentido, organizaciones sociales como "Hijas de Cuauhtémoc"38 rescatan el papel protagónico de las chicanas durante esos convulsos años.

Ese silenciamiento de las chicanas se puede observar en dos niveles: el primero tiene que ver con una narrativa que las oculta, invisibiliza o excluye, según indica Blackwell. El segundo remite a un uso del lenguaje, tanto en inglés como en español, que termina por reafirmar estereotipos femeninos.

Una mujer en la cultura chicana tenía que ser reservada, callada, sino quería pasar por "chismosa", no podía objetar lo que dijeran personas de autoridad, sino quería ser vista como "malcriada". Ser "hocicona", "repelona", "chismosa" era humillante para las mujeres. "In my culture they are all words that are derogatory if applied to women --I've never heard them applied to men" (Anzaldúa, 1987, p. 54). De ahí que la autora también

\footnotetext{
${ }^{38}$ En el contexto chicano, "Hijas de Cuauhtémoc" creó un periódico que incidió con ideas feministas en algunos sectores del movimiento. El primer periódico apareció en 1971 y sólo se publicaron tres. Los trabajos de historia oral realizados por Maylei Blackwell evidencian el activismo de las mujeres chicanas a pesar de los intentos por borrarlas (2008).

El nombre de la organización fue tomado del "Club Femenil Antirreeleccionista Hijas de Cuauhtémoc", un grupo de mujeres que exigieron sus derechos durante el porfiriato y la Revolución de 1910. El activismo de estas mujeres es considerado uno de los antecedentes que llevó a Lázaro Cárdenas a presentar en 1937 una reforma a la ley para otorgar el voto a las mujeres en México. Este dictamen fue aprobado, pero el derecho a votar fue alcanzado hasta 1953 (Erlij, 2005; Blackwell, 2008).
} 
retome términos en español para hacer un análisis histórico, descubriendo un uso despectivo y denigrativo de estos conceptos hacia las mujeres. Estas palabras juegan un papel relevante en la construcción del feminismo chicano y la edificación de una narrativa que tenga en cuenta el lugar de opresión de la mujer (justificado desde ciertos mitos y reforzado a través del lenguaje). Un ejemplo de reinterpretación y apropiación de estos términos es el de "chingada", que hace referencia a la Malinche, mujer que en la narrativa nacional mexicana es considerada como símbolo de la traición (Paz, 1950).

La palabra "chingada" Anzaldúa la utiliza para reivindicarse a sí misma como "hija de la chingada", pero no el sentido de ser hija de la "mujer violada", que es como la interpreta Octavio Paz. El ejemplo que pone Anzaldúa para establecer que es una "hija de la chingada" transgrede varios aspectos del perfil femenino "deseado" en el discurso patriarcal de los chicanos. Ella menciona que le dicen:

"¿Y cuándo te casas Gloria? Se te va a pasar el tren" $Y$ yo les digo, "Pos si me caso no va a ser con un hombre." Se quedan calladitas. Sí, soy hija de la Chingada (1987, p. 17).

En este ejemplo los sentido de la palabra "chingada van más allá de los aceptados regularmente, pues, por un lado, Anzaldúa es una mujer soltera, una mujer que está "desperdiciando" su tiempo para cumplir con la meta de casarse y tener hijos, ya que la frase "Se te va a pasar el tren" recalca que es una mujer que está en el "límite" entre quedarse como soltera o casarse, y también está en el "límite" para la reproducción. Por otro lado, la respuesta que brinda desarticula a sus interlocutoras, las deja calladas, al exhibir su lesbianismo, aspecto que rompe con el rol esperado de una mujer, porque Anzaldúa rechaza que la mujer sólo esté destinada a 
ser esposa o madre. Incluso en el texto dice que "for a woman of my culture there used to be only three directions she could turn: to the Church as a nun, to the street as a prostitute, or the home as a mother" (p. 17). Así que ser una "hija de la chingada", en el sentido que le da la autora, significa arremeter contra los modelos impuestos a las mujeres, sobre todo contra la idea de que estas tenían que guardar silencio y no rezongar.

A nivel lingüístico también le tocó lidiar con la acusación de traición, por parte de un sector de latinos, por hablar inglés, ya que la identificaban como "pocha" -ya se observó la connotación negativa que históricamente tiene este término-, "you're the speaking the oppressor's language by speaking English, you're ruining the Spanish language', I have been accused by varios Latinos and Latinas" (p. 55). Anzaldúa menciona que las chicanas que han crecido hablando el spanglish han tenido la idea de hablar mal el español: "It is illegitimate, a bastard language. And because we internalize how our language has been used against us by the dominant culture, we use our language differences against each other" (p. 58).

Así que para romper el silencio y legitimar el spanglish, lengua defendida por Anzaldúa, se debe tener coraje, ser una "hija de la chingada" para poder enfrentar los ataques por atreverse a hablar y no hacerlo de la forma en que se "espera":

I will no longer be made to feel ashamed of existing. I will have my voice: Indian, Spanish, White. I will my serpent's tongue -my woman's voice, my sexual voice, my poet's voice. I will over come the tradition of silence (p. 59). 


\subsection{Coatlicue-Tonantzin-la Virgen de Guadalupe, la Llorona y la Malinche: símbolos de una nueva narrativa chicana}

Para Andrzej Wierciński "el símbolo es un signo que agrupa en torno suyo varias acepciones" (1985, p. 9). De ahí que no sea posible la univocidad en torno a éste. Cuando se interpretan los símbolos tenemos que considerar que la ambigüedad está presente, pues estamos frente a un signo que "no agota nunca por entero su significación" (García, 2012, p. 128). Según Lotman, "el símbolo se correlaciona activamente con el contexto cultural, se transforma bajo su influencia, pero también lo somete a transformación" (2002, p. 91, 92), es decir, existe una "función dual" del símbolo, ya que, por un lado, forma parte de una herencia cultural; y por otro lado, permite que haya una variabilidad en su sentido. Por ello, "nos encontramos con otra dimensión que metodológicamente es importante atender: todo símbolo forma parte de la memoria cultural, de la memoria colectiva" (García, 2012, p. 134). Resulta relevante, antes de plantear una reinterpretación, atender a la herencia en la que se inserta un símbolo, pues su "deconstrucción", en el sentido derridiano, no puede "ocultar" o "negar" el contexto cultural en el que se ha encontrado y se encuentra inserto. En este sentido, se toma la noción de "deconstrucción" porque, como menciona Derrida, no se trata de un término negativo, sino de indagar cómo se construyeron algunos símbolos a través de su dimensión histórica, "no para destruir, demoler o purificar, sino para acceder a sus posibilidades y significados, a su construcción y a su historia" (1993, p. 1). Por eso el término "deconstrucción" resulta apropiado para abordar los símbolos de la Virgen de Guadalupe, de la Llorona y de la Malinche, pues Anzaldúa no propone su destrucción, ni su abandono, sino una indagación, una crítica que permita resignificarlos.

La Virgen de Guadalupe, la Llorona y la Malinche son figuras centrales para la narrativa de Anzaldúa, porque a través de estos tres símbolos femeninos la autora exhibe las creencias y estereotipos que han 
dominado y justificado los roles de las mujeres en la sociedad chicana y mexicana. Muchas de esas creencias y estereotipos son infundadas para la autora, quien advierte que ha existido una narrativa tendenciosa sobre los papeles que estas figuras han asumido históricamente. En este sentido, habla de una tergiversación de figuras como la Llorona y la Malinche que resalta las características "negativas" de la mujer. Pocas versiones destacan un sentido "positivo" de ellas. En cambio, la Virgen de Guadalupe sí respondería a un figura "positiva" dentro de la sociedad chicana, pues se utiliza en un doble sentido: por un lado, es la madre indígena, la que reconoce a los desprotegidos, pero, por otro lado, refuerza las condiciones "deseables" de una mujer en el catolicismo oficial, porque se muestra pasiva y abnegada: "Guadalupe has been used by the Church to mete out institutionalized oppression: to plácate the Indians and mexicanos and Chicanos". En cambio, la Malinche (Chingada) ha simbolizado la traición indígena hacia el propio pueblo mexicano y, en vez de verse como el puente lingüístico que dio inicio al encuentro de dos mundos, es vista como la indígena traidora. De ahí que, en la narrativa hegemónica, "la Chingada to make us ashamed of our Indian side" (Anzaldúa, 1987, p. 31).Mientras que el Ilanto de la Llorona representa el sufrimiento que "merece" una mujer que decidió acabar con la vida de sus hijos. Sin embargo, para la autora estas tres mujeres son protectoras de los chicanos y son símbolos fundamentales en la narrativa que se pretende construir.

La gente Chicana tiene tres madres. All three are mediators: Guadalupe, the virgin mother who has not abandoned us, la Chingada (Malinche), the raped mother whom we have abandoned, and la Llorona, the mother who seeks her lost children and is a combination of the other two (p. 30). 
La mención de estas significaciones y el lugar que ocupan en la cultura chicana son pautas que revisan la mirada y la reinterpretación de la herencia recibida con la finalidad de visibilizar, desde una narrativa no patriarcal, estas figuras.

\section{En busca del equilibrio perdido}

Hay un punto clave en la reinterpretación de la Virgen de Guadalupe, la Malinche y la Llorona, dicho punto radica en el rastreo de las culturas indígenas, previo a la hegemonía de los aztecas, para mostrar que existía un equilibrio entre lo masculino y lo femenino (1987, p. 31). Enah Montserrat Fonseca describe que en el período Precolonial se pueden detectar dos abordajes sobre el género que determinaban los roles de las mujeres. Tal es el caso de "Teotihuacan [...] (200 a.C.-1500 d.C.) y de Tenochtitlan [...] (1200-1521 d.C.), para quienes el género fue una categoría social total y rotundamente diferente". En Teotihuacan la cuestión del género tendió a difuminarse. Mientras que en Tenochtitlán se realizó una división del género, con roles bien definidos. Lo masculino era asociado con "el cielo, el sol, la vida, la energía positiva, el fuego, la luz, el día, lo caliente" (2011, p. 77). Por su parte, lo femenino era relacionado con los contrarios de las características masculinas descritas. También "la dimensión de lo femenino se identificaba con las nociones: débil, pasivo, cobarde, penetrado, sumiso, vencido" (Rodríguez-Shadow y Campos, 2011, p. 109). El dominio azteca significó la prevalencia de un estado en donde lo importante era la guerra y, en consecuencia, los guerreros adquirieron un papel protagónico, mientras las mujeres fueron relegadas a un ámbito doméstico (Fonseca, 2011; Rodríguez-Shadow y Campos, 2011). 
La reafirmación de que la mujer estaba destinada al hogar tenía una dimensión ritual, pues "la partera enterraba ${ }^{39}$ el cordón umbilical de la recién nacida junto al hogar, en señal de que la niña no saldría de la casa para realizar correctamente las labores propias de su sexo" (Fonseca, 2011, p. 79). Desde pequeñas se les enseñaba que "su finalidad en esta vida consistía únicamente en la procreación, la educación de los hijos y el servicio de los demás" (Rodríguez-Shadow y Campos, 2011, p. 107). Así, la maternidad era un aspecto impuesto a las mujeres, pero también era una característica que las glorificaba, porque tener hijos significaba contribuir con guerreros para el imperio.

Esta anulación del equilibrio tiene una manifestación "objetiva" con el gobernante azteca Itzcóatl quien consciente del papel que desempeñaban los códices en la sociedad como registro y resguardo de la memoria, decidió crear una nueva narrativa a la vez que eliminó los códices antiguos. "The Aztec ruler, Itzcoatl, destroyed all the painted documents (books called codices) and rewrote a mythology that validated the wars of conquest and thus continued the shift from a tribe based on clans to one based classes" (Anzaldúa, 1987, p. 32). Miguel León-Portilla, en Toltecayotl, aspectos de la cultura náhuatl, también menciona esta política del gobernante azteca y profundiza sobre la importancia que tenía el recuerdo para las culturas indígenas, de ahí que a Itzcóatl lo describa como un gobernante que entendió que para lograr la sociedad "deseada" tenía que eliminar los registros que contradecían su concepción. "Era pues necesario reinterpretar el pasado para tener en él nuevo apoyo del destino que aguardaba a los seguidores de Huitzilopochtli" (1980, p. 65, 66). Todorov también retoma este evento como un ejemplo de lo que denomina "memoria amenazada", porque forma parte de los abusos de la memoria (2000, p. 11). Sin embargo, algunas de estas "memorias amenazadas" logran por medio de poesías, esculturas y relatos orales permanecer pese a los intentos por eliminarlas. Por ejemplo, en algunas esculturas del imperio azteca se observan dos

${ }^{39}$ En cambio, el cordón umbilical de los hombres era enterrado en el campo de batalla (Wierciński, 1985). 
narrativas: mientras una de ellas reafirma el rol de la mujer dentro del hogar y como madre; la otra le da atributos andróginos, por lo que, según Fonseca, coexisten dos discursos. "La ideología oficial refuerza el dominio masculino, devalúa el papel de reproductora de la mujer, pero las figurillas cerámicas cuentan otra historia, un discurso de resistencia del dominio del culto estatal" (2011, p. 84). Aunque, para María J. Rodríguez-Shadow y Lilia Campos Rodríguez, esa transgresión en muchas ocasiones llegó a pagarse con la muerte (2011, p. 112).

Este panorama muestra que la imposición azteca sobre la forma en que se asumían los roles de género no difería mucho de la concepción que posteriormente llegó con los españoles, por eso no resultan del todo sorprendentes las narrativas sobre la Malinche, la Virgen de Guadalupe y la Llorona, pues de ambos lados (indígena y español) existía una noción negativa de lo femenino. Asimismo, destaca el acercamiento que hace Anzaldúa hacia las culturas indígenas para mostrar que lo femenino no siempre respondió a lo "negativo", pero también para evidenciar cómo el control de la mujer, su sometimiento a nivel sexual, político y económico se hizo desde la violencia, imponiendo un estado guerrero.

\section{Coatlicue-Tonantzin-Guadalupe}

El sincretismo religioso solía reunir y vincular figuras de diversas creencias religiosas. Este fenómeno supone la creación de nuevas concepciones, producto de la pugna entre diversas culturas. Una versión afable del sincretismo supone que las culturas en conflicto salen ganando, pues se genera algo "nuevo" (Gussinyer, 1996). Aunque en el México colonial los conquistadores trataron de eliminar la religión prehispánica para sustituirla por la católica a través de la imposición. Esto generó una mezcla entre elementos paganos y cristianos, pues las creencias no se eliminan destruyendo códices, templos o edificios. Como previamente se mencionó, 
los indígenas encontraron resquicios para continuar practicando sus ritos y creencias, sin embargo, estas prácticas estaban relegadas a un ámbito privado en el sentido de que era una actividad "oculta" para los españoles. Así, algunos indígenas practicaban la religiosidad católica rindiendo tributo a los dioses indígenas.

El dualismo religioso y el sincretismo de elementos paganos y cristianos dentro de un mismo culto sentó las bases para una más completa cristianización de los indios mediante la decadencia gradual o la desaparición total del ritual pagano privado y el fortalecimiento de los elementos católicos de los cultos sincretizados (Carrasco, 1975, p. 202).

De esta forma, se terminó por relacionar a los dioses indígenas con los santos católicos. Un ejemplo de esto lo encontramos entre la diosa Tonantzin y la Virgen de Guadalupe (Carrasco, 1975), un caso emblemático del sincretismo religioso. La narrativa sobre este acontecimiento indica que, en 1531 en lo que hoy es la Ciudad de México, a un indígena llamado Juan Diego se le "apareció", en varias ocasiones, la Virgen de Guadalupe en el cerro del Tepeyac. Él fue el encargado de dar a conocer a los jerarcas católicos del Virreinato la aparición y el mensaje de la Virgen (Anzaldúa, 1987; Díaz, 2002; León-Portilla, 2000).

En el caso de Anzaldúa, su familia conservó rituales que estaban cerca de la religiosidad indígena, ya que, en su casa, como acontecía en muchas familias chicanas, se practicaba un "catolicismo folclórico", con muchos elementos paganos, por eso menciona que "mama grande Ramona toda su vida mantuvo un altar pequeño en la esquina del comedor. Siempre tenía las velas prendidas. Allí hacía promesas a la Virgen de Guadalupe". La autora expone un deslinde del catolicismo romano e introduce a la diosa 
Coatlicue como el vínculo con la herencia indígena (Anzaldúa, 1987, p. 27; Gómez, 2001, p. 7). Esta diosa es la madre de una de las deidades centrales en los mexicas: Huichilopoztli. Coatlicue también es identificada como "la de la falda de serpientes", y antes de la llegada de los españoles se le adoraba como Tonantzin en el Cerro del Tepeyac (Lafaye, 1993, p. 304; León-Portilla, 2000, p. 13; Paz, 1950, p. 35).

Anzaldúa recurre a la diosa Coatlicue no sólo para encontrar el nexo con el pasado indígena, sino para armar una estrategia, usada por otras autoras chicanas, con el fin de quitar o sacudir de la imagen tradicional la pasividad y la abnegación de la Virgen de Guadalupe, pues Coatlicue (asumida como antecesora de Guadalupe) representa la dualidad y se aleja de ser una diosa que sólo sea benéfica y pasiva (Gewecke, 1996, p. 22).

Entre las versiones que reafirman sólo el papel de madre abnegada y protectora de la Virgen encontramos la de Octavio Paz quien sostiene que, a diferencia de Tonantzin (quien era identificada como diosa de la fertilidad), el "atributo principal no es velar por la fertilidad de la tierra sino ser el refugio de los desamparados [...], es el consuelo de los pobres, el escudo de los débiles, el amparo de los oprimidos. En suma, es la Madre de los huérfanos" (1950, p. 35). Paz dibuja una Virgen que funciona y ha funcionado, desde la llegada de los españoles, como la "madre" que no resuelve la condición humana de opresión, pero ayuda a entenderla. Anzaldúa no niega el papel de madre de la Virgen, pero encuentra una concepción de Coatlicue y Tonantzin, en el mundo indígena, que le permite resignificar a la Virgen de Guadalupe desde la dualidad de principios, pues, como sostiene LeónPortilla, Tonantzin representa al "padre" y a la "madre": "Tonantzin, nuestra madre, Tonantzin, nuestro padre, eran conceptos claves en el pensamiento nahua que así concebía a 'aquel por quien se vive', supremo dador de la vida" (2000, p. 59).

Otro de los factores que terminó generando un vínculo significativo para que la Virgen de Guadalupe "sustituyera" a las divinidades indígenas fue que "eligió" para la transmisión de su mensaje al indígena Juan Diego, 
perteneciente al sector social de los macehuales, es decir, de la gente "común". En el "Nican Mopohua" (2000) se remarca esta figura de desprotección del indígena Juan Diego, cuando éste insiste en que él no es el indicado para llevar el mensaje de la Virgen al obispo, y después de sentirse ignorado por el jerarca católico en la primera visita, ya no quiere ser el mensajero:

Por eso, mucho te ruego, señora mía, nombre señora, mi muchachita, que a alguno de los preciosos nobles, los conocidos, reverenciados, honrados, así le encargas que lleve, que conduzca tu reverenciado aliento, tu reverenciada palabra, para que así sea creída (León-Portilla, 2000, p. 133).

Sin embargo, la Virgen insiste en que debe ser él, Juan Diego, "uno de sus hijos más queridos". De ahí que el mito de la aparición de la Virgen de Guadalupe haya tenido un eco significativo en la población indígena, primero porque elegía a uno de los miembros del pueblo oprimido y segundo porque retomaba elementos que estaban estrechamente relacionados con la simbología de Coatlicue-Tonantzin, este último punto explica el recelo que muchos frailes tuvieron en un inicio, pues creían que en realidad se trataba de una veneración simulada a la Virgen de Guadalupe. Como argumenta Carlos Guerrero Velázquez: "La imagen de la Virgen de Guadalupe no sustituyó a la diosa azteca, y si se pretendió que lo hiciera, no se consiguió borrar la fuerte impronta que dejó Tonantzin". De esta forma, la Virgen de Guadalupe logró trascender en el mundo colonial gracias a esa conexión que se realizó entre las características de Tonantzin y la nueva virgen de origen cristiano: "La fuerte devoción mariana que se establece en las colonias por parte de los sectores populares, está ligada a la existencia de 
diversas divinidades femeninas en las culturas precolombinas, las cuales estuvieron vinculadas principalmente con la fecundidad" $(2013$, p. 159, 164).

Una vez que se instala la Virgen de Guadalupe como símbolo del catolicismo y que es aceptado por los distintos sectores, se vuelve un factor fundamental dentro de ámbitos políticos y religiosos, debido a que es una de las figuras femeninas dentro de la cultura mexicana a la que se le da un lugar primordial y a la que se recurre ante acontecimientos trascendentes para el rumbo del país (León-Portilla, 2000). También "la imagen de la Guadalupe sirvió como alegoría para la nueva patria cuyas representaciones afirmaron la identidad de los nacidos en la Nueva España" (Godínez, 2017, p. 137). Uno de los eventos históricos más importantes en la nación mexicana, en donde la recurrencia a la Virgen ha sido emblemática, es el de la Independencia de México en 1810 (recordemos el uso de la imagen de la guadalupana por el que es considerado uno de los Padres de la Patria: Miguel Hidalgo). Anzaldúa considera que es a partir de la Independencia de México, lucha que se prolongó de 1810 a 1821, que la Virgen de Guadalupe cobró una relevancia sin precedentes: "Desde entonces para el mexicano ser Guadalupano es algo esencial/ Since then for the mexican, to be a Guadalupano is something essential". Se sabe que en la historia chicana el uso del estandarte guadalupano es uno de los símbolos más conocidos y utilizados durante las marchas en busca de mejoras laborales realizada por este grupo (Díaz, 2002, p. 37). Como afirma Anzaldúa: "During the 1965 grape strike in Delano, California and in subsequent Chicano farm workers marches in Texas and other parts of the Southwest, her image on banners heralded and united farm workers" $e$ incluso añade "in Texas she is considered the patron saint of Chicanos" (1987, p. 29, 30).

Esta veneración hacia la Virgen de Guadalupe se debe a que es una figura que representa el mestizaje de dos mundos: el "viejo" y el "nuevo". De esta forma, en la cultura chicana se hace una reapropiación de la imagen al considerar que ellos, los chicanos, también son el resultado del cruce entre culturas. Además, para los chicanos el guadalupanismo resulta 
trascendente, pues el culto a la Virgen de Guadalupe es la elección de una madre que se identifica más con lo indígena. Pero también es una reapropiación feminista del símbolo, porque para las chicanas no se trata de una madre sumisa, sino de una madre en la que confluyen dualidades que generan un equilibrio-masculino/femenino, vida/muerte, abnegada/rebeldeque se logra con el aporte de Coatlicue-Tonantzin, pues desde la mirada católica sólo se sostiene la versión de la madre protectora y abnegada.

Our faith is rooted in indigenous attributes, images, symbols, magic and myth. Because Guadalupe took upon herself the psychological and physical devastation of the conquered and oppressed indio, she is our spiritual, political and psychological symbol...To Mexicans on both sides of the border, Guadalupe is the symbol of our rebellion against the rich, upper and middleclass; against their subjugation of the poor and indio (Anzaldúa, 1987, p. 30).

\section{La "Llorona": de la mujer "maldita" a la "rebelde"}

La leyenda de la "Llorona" es una de las más conocidas en la cultura popular mexicana, aunque pueden encontrarse relatos similares en otras culturas, en donde las mujeres lloran por sus hijos (González, 2013, p. 542). Proviene de la tradición oral y sigue presente en contextos rurales y urbanos. Si bien a lo largo de los años se han ido modificando detalles del relato, la forma en que "aparece" sigue conservando cierta homogeneidad: se trata de una mujer, vestida de blanco, que se presenta por las noches y grita por sus hijos, específicamente dice "jayyy, mis hijos!" (Rodríguez y Verduzco, 2009, p. 311). Sobre esta leyenda existen, principalmente, dos versiones: la 
precolombina y la colonial (González, 2013). La única similitud que hay en los dos relatos es que se habla de una mujer que se lamenta, presagiando malos augurios: "La Llorona siempre se asocia con el dolor, la pena, la tristeza, la desesperación y un destino trágico" (Nogues, 2005, p. 64). Lo que cambia de manera considerable es la concepción sobre lo femenino en ambas figuras, pues mientras en el relato precolombino la mujer que llora es relacionada con la diosa Cihuacóat ${ }^{40}$, también identificada con Coatlicue y Tonantzin (Anzaldúa, 1987; Godínez, 2014), en la versión colonial se habla de una mujer "indígena, mestiza, criolla, nunca peninsular" y despechada, que en un arranque fue capaz de matar a sus hijos (González, 2013, p. 547).

Miguel León-Portilla, en Memoria Azteca de la Conquista, señala que los aztecas mencionaron a una mujer que lanzaba lamentos previos a la llegada de los españoles, como un presagio de lo que iba a pasar:

Presagio: Muchas veces se oía: una mujer lloraba; iba gritando por la noche; andaba dando grandes gritos.

- $\mathrm{i}$ Hijitos míos, pues ya tenemos que irnos lejos!

Y a veces decía:

-Hijitos míos, ¿a dónde os llevaré? (2000, p. 32)

Se ha vinculado a esa mujer con la diosa Cihuacóatl, "mujer serpiente", quien es identificada con la madre de Quetzalcóatt ${ }^{41}$. De ahí que quienes interpretaron el presagio antes descrito como un lamento que hacía la diosa, lo consideraron un recurso para proteger a sus hijos. Además, lo leyeron como la derrota de la "diosa serpiente", que a su vez

\footnotetext{
${ }^{40} \mathrm{~A}$ esta diosa se le asocia con los ríos y los mares, "murió al dar a luz, por lo que es protectora de las mujeres que se mueren en su primer parto" (González, 2013, p. 545).

${ }^{41}$ Es considerado una de las principales deidades en el México prehispánico. Quetzalcóatl significa "serpiente emplumada" y "era dios del viento, de Venus, del alba, de los gemelos, de los monstruos, de la energía vital, de la fecundidad: engendró a los seres humanos" (Ocaña, 2004, p. 70).
} 
implicó el sometimiento y ocultamiento de otras diosas femeninas, es decir, no se trató sólo de la advertencia a sus hijos por el sufrimiento que venía, producto de la llegada de los españoles, sino también del presagio de su pérdida como "madre", los hijos que ya no le "pertenecerán", por los que está destinada a seguir gritando "jay, mis hijos!” (Godínez, 2017, p. 135).

En la época colonial se observa un cambio importante en el relato sobre la Llorona. Durante este período comienza a correr una versión donde, como se ha adelantado, se trata de una mujer indígena, mestiza o criolla, pero nunca española. Se dice que se enamora de un español y tienen hijos, pero no se casa con ella porque no es española. Esta mujer se siente traicionada y mata a sus hijos: en algunas versiones los ahoga en una laguna (Rodríguez y Verduzco, 2009, p. 313), en otras los apuñala (González, 2013, p. 547). La Llorona se arrepiente de su crimen y se quita la vida. En esta versión se presenta a una mujer que no puede controlar sus impulsos, que es capaz de cometer los crímenes más atroces por despecho, y su castigo será penar por las noches, lamentando la pérdida irreparable, pues el filicidio es imperdonable. Este castigo representa también la exclusión social de una mujer que no fue capaz de proteger y reivindicar un aspecto considerado sagrado dentro de religiones como la católica: la maternidad (Lamas, 2012, p. 44).

Sylvie Nogues retoma el lamento de la Llorona y realiza una interpretación (a partir del cuento "El arroyo de la Llorona" de Sandra Cisneros, autora chicana) en la que argumenta que éste es una forma de protesta ante una organización social que se impone sobre las mujeres por medio del uso de la fuerza. La Llorona representa el rechazo del orden patriarcal, en donde las mujeres tienen marcado un "destino" de servicio al hombre. Ese lamento se reinterpreta como una forma de alzar la voz y rebelarse frente a los opresores, eliminando el sentido pasivo del grito, porque en el relato colonial sólo puede quejarse por lo que hizo, pero no cambiarlo: "la Llorona no tiene un auténtico lenguaje para siquiera explicar quién es. Está condenada a una casi mudez de hecho" (2005, p. 70). Este 
lamento también es retomado por Anzaldúa como una forma de protestar de las mujeres que tenían que despedir a sus hijos para participar en la guerra (sobre todo durante el dominio de las aztecas), era la forma en que mostraban su inconformidad a una sociedad que glorificaba al guerrero y en donde las mujeres no podían impedir que sus hijos fuesen tomados y preparados como guerreros (1987, p. 33). Para la autora chicana, el lamento sigue siendo una forma de queja de las mujeres mexicanas y chicanas ante una sociedad que las condena al silencio.

Anzaldúa relata que cuando ella era pequeña le contaban que la Llorona $^{42}$ se le "aparecía" a quienes andaban en malos pasos y se utilizaba para asustar a los niños (p. 35). Pero la autora considera que se trata de la diosa Cihuacóatl, quien en una ocasión se le "apareció" a ella en forma de serpiente, sintió su "presencia". A partir de entonces, Anzaldúa valoró las narrativas que le contaban de pequeña, ya que la "racionalidad" blanca había provocado que desestimara todo tipo de creencias que hicieran referencia a otro mundo (p. 36). Ahora bien, no sólo critica la "racionalidad", también sostiene que el catolicismo institucional ha contribuido con el descrédito de las creencias populares con su universo de espíritus, a las que califica de brujería. Así, la crítica central tanto a la "racionalidad" como al catolicismo tiene que ver con la separación del mundo espiritual y del racional, aspecto que ha violentado a los humanos, obligándolos a elegir alguna de esas "realidades" como si estuvieran separadas (p. 37).

La presencia de la Llorona en Anzaldúa muestra la subalternización de creencias por considerarlas "primitivas", una forma más de violencia sobre los chicanos. En esas reinterpretaciones de Anzaldúa hay una reivindicación de las creencias de sus antepasados, una voluntad de volcar lo que trae dentro, que no es ni lo que le dicta la racionalidad ni las tradiciones sobre la maldad femenina.

\footnotetext{
${ }^{42}$ En el Valle del Río Grande, donde pasó parte de su vida Anzaldúa, en muchas ocasiones a la Llorona la llamaban la "Jila".
} 
Así, La Llorona (Cihuacóatl) no llora por haber matado a sus hijos, sino porque se los arrebataron: "I remember la Jila following me once, remember her eerie lament. I'd like to think that she was crying for her lost children, los Chicanos/mexicanos" (p. 38).

\section{La Malinche: la mujer "maldita"}

"Malinalli-Tenepal, Malinche, Malitzin, doña Marina, mujer e indígena, madre y puta, traidora y útero simbólico de la nación mexicana, personaje ambiguo, así es como se nos presenta a la Malinche" (Núñez, 2002, p. 9), es otra de las figuras femeninas centrales en el análisis que realiza Anzaldúa al considerar que las interpretaciones que se han hecho sobre ésta han moldeado la creencia de que el lado indígena de las mujeres es traidor (1987, p. 22). Incluso en la actualidad el término es utilizado para describir a aquellos sujetos que "prefieren lo extranjero a lo mexicano", son malinchistas, prácticamente "traidores de la patria" (Paz, 1950; Miralles, 2004; Núñez, 2002). La "traición" de la Malinche consiste en haberse enamorado del verdugo de algunos indígenas: Hernán Cortés (Bartra, 2006, p. 203).

Octavio Paz indica que la Malinche también es la madre "chingada", por lo que la va a identificar con la Chingada. La Chingada es la mujer violada, la mujer que no tuvo opción y fue humillada, a diferencia de la "puta" que tiene relaciones por "placer" (Paz, 1950, p. 33).

Si la Chingada es una representación de la madre violada, no me parece forzado asociarla a la Conquista, que fue también una violación, no solamente en el sentido histórico, sino en la carne misma de las indias. 
El símbolo de la entrega es la Malinche, la amante de Cortés (p. 35).

Paz presenta a la Chingada como una mujer despreciable por su pasividad: "Esta pasividad abierta al exterior la lleva a perder su identidad: es la Chingada. Pierde su nombre, no es nadie ya, se confunde con la nada, es la Nada. Y sin embargo, es la atroz encarnación de la condición femenina" (p. 35). De esta forma, "los mexicanos descendemos de dos actos brutales: la traición y la violación" (Belausteguigoitia, 2015, p. 31), ambos actos encarnados por una mujer. Anzaldúa se posiciona en contra de esta visión de Paz, pues va a sostener que la Malinche no fue la que vendió a su gente, sino su gente a ella. Para la autora ese acontecimiento en donde la Malinche se "ofrece" a Hernán Cortés ha sido utilizado para concebir a la mujer como una traidora, aspecto que la ha silenciado por años, pues las mujeres han asumido lo que se dice de ellas, "male culture has done a good job on us. Son los (sic) costumbres que traicionan". Las mujeres que crecieron bajo el manto de esas creencias llevan más de 300 años considerándose inferiores y traidoras. Una traición que en muchas ocasiones las ha condenado al silencio y al ostracismo, pues no son dignas de alzar la voz, de mirar de frente al hombre que se siente dueño de ellas (1987, p. 22, 23).

La Malinche no es para Anzaldúa una traidora, es un símbolo del mestizaje, pues ella aprendió a hablar una nueva lengua, fue un puente lingüístico (León-Portilla, 2002, p. 37). La Malinche vivió en "Nepantla", en ese lugar intermedio, el mismo en el que viven los chicanos. Pero también representa a una mujer "quebrantada por la lengua y un cuerpo quebrado y atravesado por desigualdades raciales, de clase, de género..." (Belausteguigoitia, 2015, p. 32), como les pasa a los chicanos y a los que viven una cultura de frontería. 
Para Anzaldúa la conquista de México no se debió a la traición de la Malinche, sino al recelo y la animadversión provocadas por ciertas costumbres brutales de los aztecas (violación de las mujeres en las invasiones y altos impuestos) practicadas en los pueblos circundantes: "Thus the Aztec nation fell not because Malinali (la Chingada) interpreted fort and slept with Cortés, but because the ruling elite had subverted the solidarity between men and women and between noble and commoner" (1987, p. 34).

\subsection{Construcción de una "memoria Nepantla" a través de la "Nueva Mestiza"}

En esta tesis se introduce la noción de "memoria Nepantla". "Nepantla" es un término náhuatl que se deriva de la palabra "panotla" (que significa puente) y se traduce como "tierra de en medio" (Joysmith, 2015; Keating, 2007). La palabra es retomada por Anzaldúa (1987, p. 138) para reflexionar sobre la experiencia de habitar en distintas sociedades y transitar entre unas y otras (Joysmith, 2015, p. 12). Si bien, la noción de "puente" se puede asumir como un camino de "ida y vuelta", la idea de retorno no es concebida como el regreso a un punto previo, es más bien la llegada a una zona distinta. En este sentido, "Nepantla" se asocia "con un estado liminal dentro del rito de paso que experimentan los sujetos diaspóricos o migrantes" (Prieto, 2015, p. 65). Anzaldúa indica que "continually walk out of one culture/ and into another,/ because I am in all cultures at the same time" (1987, p. 77). Por lo que ha estructurado una "epistemología del Nepantla" al "nombrar y sondear las profundidades del reservorio de saberes de las liminalidades no articuladas, de sus complejas realidades, sus vastos imaginarios" (Joysmith, 2015, p. 13). Así, "la desorientación y la 'mirada de cabeza" son, para Anzaldúa, puntos de partida para lograr una epistemología alternativa, abierta a la diversidad y tolerante a la diferencia". Ya Mignolo había planteado la importancia de "Nepantla" no sólo como estado liminal, sino como un "entramado epistemológico" procedente de 
grupos subalternos que tienen que posicionarse frente a un desequilibrio en las relaciones de poder (Prieto, 2015, p. 66, 69).

Esta nueva epistemología brinda otra mirada hacia narrativas sobre el pasado que pretenden ser homogéneas y unívocas. De ahí que proponemos la noción de "memoria Nepantla" (derivada de la "epistemología del Nepantla") porque contribuye a detectar y analizar las intersecciones que generaron una narrativa que intenta ser hegemónica, pero también desentraña los conflictos y los sentidos que articulan otros discursos. En este sentido, la "memoria Nepantla" detecta los delgados y finos hilos que componen ciertas narrativas en donde a "simple vista" se escapan las justificaciones que siguen sosteniendo "los imaginarios patriarcales y nacionalistas" (Prieto, 2015, p. 69), que excluyen a las mujeres, las y los diferentes, los y las pobres, las y los prietas/os. Asimismo, esta memoria asume un estado de transición constante, porque aunque surja una nueva narrativa, esto no significa que sea definitiva, estará sujeta a cambios, tensiones y pugnas, pues sobre el pasado lo más riesgoso que se puede decir es que "ya se ha dicho todo". Esta "memoria Nepantla", producto del "pensamiento fronterizo" 43 y del "paradigma otro", se conecta con las memorias y las experiencias de la "otra parte de la modernidad", de aquella que ha sufrido en carne propia los estragos de la colonialidad (Mignolo, 2003). Ya no se trata de conceder que otros narren y dirijan determinadas miradas hacia el pasado, sino de romper el silencio, apropiarse de la narración para que emerjan las "otras memorias".

$\mathrm{Si}$ "borderlands" y "frontería" son términos que describen los cruces culturales, la mezcla de creencias, los límites difusos por el encuentro de distintos grupos sociales, la "memoria Nepantla" describe esa construcción

43 Para Mignolo el "pensamiento fronterizo" surge desde el siglo XVI, con lo que llama la "invención de América", y se ha prolongado a través del capitalismo. Ahora bien, la característica del "pensamiento fronterizo" es que reconoce el peso de la modernidad, pero no se somete a ésta. "El pensamiento fronterizo fuerte surge de los desheredados, del dolor y la furia de la fractura de sus historias, de sus memorias, de sus subjetividades, de su biografía [...]" (2003, p. 28). 
discursiva que parte de la diferencia, de la alteridad y reconoce la diversidad cultural. Se trata de una narrativa en la que se retoman las "otras memorias", esas que no tienen lugar en las versiones hegemónicas. Por eso, en esta memoria se engloban ritos, creencias, lenguas y símbolos que se entrelazan para mostrar una narrativa incluyente y abierta hacia los "otros". Un discurso que recupera las memorias subterráneas (Pollak, 2006), que construye una memoria justa (Vezzetti, 2009) y evita los abusos de la memoria (Todorov, 2000). Así, en Borderlands...se nos muestra una mirada hacia los chicanos y las chicanas que reinterpreta la posición del grupo en la sociedad estadounidense, ya que históricamente habían sido un sector relegado dentro de la sociedad "gringa".

Los chicanos han fincado en el conflicto entre México y Estados Unidos de América la construcción de su identidad, pues Anzaldúa considera que a través de engaños y abusos fueron despojados de un territorio que les pertenecía. De ahí que mirar hacia el momento en que pasaron a ser extranjeros dentro de su propio territorio sea para la autora una tarea fundamental, porque genera una narrativa de pertenencia, pero también lleva a reflexionar sobre ese paso de ser locales a extranjeros dentro de un territorio que alguna vez fue suyo, esa es una muestra de la transitoriedad, un cambio no elegido, una situación impuesta, por eso la necesidad de permanecer alerta. Esa mirada histórica también los lleva a pensar que no podrán recuperar lo que alguna vez fue de ellos, pero al menos tienen la legitimidad para habitar ese espacio, para resignificar el territorio.

Asimismo, encontramos la reivindicación de una lengua como el spanglish, resultado del cruce y ejemplo de la riqueza de las palabras y la imposibilidad de detener su uso, aunque no sea reconocida, pues el spanglish es una lengua viva. Así, lo que Anzaldúa reivindica con su defensa del spanglish es la inevitabilidad de que las lenguas cambien, se transformen y se reinventen.

También, Anzaldúa explora las memorias buscando articular prácticas políticas desde el testimonio escrito con el que desplaza el relato de los 
vencedores para dar paso al de los vencidos. Este desplazamiento va desde los indígenas conquistados por España, el territorio apropiado por Estados Unidos y las mujeres sometidas a un orden patriarcal. Operación similar encontramos en Traverso (2007) y en Vezzetti (2009) cuando realizan una distinción entre las memorias que glorifican las hazañas nacionales (exaltando héroes, mártires, guerras y victorias) buscando homogeneizar los lazos que unen a los ciudadanos, y aquellas memorias centradas en los testimonios de quienes han sido testigos y sobrevivientes de diversas atrocidades, a través de sus relatos cuestionan las proezas que justifican las memorias nacionales y su pretendida homogeneidad.

Además, observamos que la autora se reapropia de símbolos femeninos haciendo una deconstrucción de su concepción tradicional dentro de un discurso hegemónico. Por lo que no sólo se abre la posibilidad de tener nuevas interpretaciones de la Virgen de Guadalupe, la Malinche y la Llorona, sino que se rescatan nociones que se encuentran fuera de las narrativas dominantes. Un ejemplo claro de esto se observa en el caso de la Virgen de Guadalupe, cuando Anzaldúa resalta que en su familia se practicaba un ritual diferente al del catolicismo romano. En el caso de la Llorona se plantea una reinterpretación del lamento, pues se suele asumir que es el castigo de la mujer que ha matado a sus hijos, pero la autora chicana propone que se trata de una forma de protestar, de quejarse ante la inconformidad por lo que se espera de ella y el desacuerdo por el destino que tendrán sus hijos (como es el caso de las mujeres que lloraban cuando los hijos eran llevados a la guerra en el impero azteca). Mientras que la Malinche es vista como la mujer que inició el mestizaje, la que generó un puente lingüístico entre dos culturas, una mujer que no es traidora, sino generadora.

De esta forma, la "memoria Nepantla" es una de esas memorias otras que habitan las "tierras de en medio", es una zona de frontería/Borderlands. Por lo que esta memoria se conecta con la propuesta de la "Nueva 
Mestiza"44 que realiza Anzaldúa, ya que realza una narrativa abierta a la alteridad, en donde se asume una pertenencia a distintas culturas. Prieto argumenta que esta propuesta la realiza para recordarnos que los encuentros culturales, los cruces entre culturas no llegaron a su fin con la llegada de los españoles a América. La "Nueva Mestiza" trasciende el contexto de la comunidad para tender puentes y generar alianzas con otras personas, porque

la tierra de en medio no es de nadie (o es de todas), es un espacio que puede ser habitado por la búsqueda y el proceso incesante de construirse una identidad y una comunidad que al fin y al cabo es tan imaginaria como cualquier otro sitio fundacional (Tabuenca, 2015, p. 100).

Para la "Nueva Mestiza la ambivalencia no representa un aspecto indeseable, porque de lo que se trata es de cuestionar los paradigmas que se erigen como "verdades absolutas". En este sentido, "en unas pocas centurias, the future will belong to the mestiza. Because the future depends on the breaking down of paradigms, it depends on the straddlings of two or more cultures". Su tarea es reconocer sus herencias para distanciarse de los elementos que la dañan, como son el "machismo" y la marginación derivada de su condición de mujer, de su color de piel y de su lengua. Una vez que reconoce estos elementos perniciosos "She reinterprets history and, using new symbols, she shapes new myths" (Anzaldúa, 1987, p. 80, 82).

\footnotetext{
${ }^{44} \mathrm{Si}$ bien ya se habían señalado los problemas que el término "mestizaje" acarrea en la construcción de una narrativa nacional en México, "para la poeta chicana el concepto de mestizaje opera en resistencia a la ideología anglosajona del melting-pot (crisol dentro del que supuestamente se "derriten" los inmigrantes para producir 'al hombre americano')" (Prieto, 2015, p. 64).
} 
Configuración de una "memoria Nepantla" en Borderlands...

Maestría en Historia y Memoria

Universidad Nacional de la Plata

La "Nueva Mestiza" arremete contra los discursos nacionalistas, tan vigentes hoy en día como hace más de tres décadas. En vez de replegarse hacia un discurso esencialista para rechazar o negar al "otro", Anzaldúa apuesta por la apertura hacia la diferencia, asumiendo nuestra transformación al estar en contacto con otras alteridades. 


\section{Conclusiones}

Los discursos nacionalistas se han posicionado nuevamente en gran parte de los estados-nación. Se diserta sobre los "otros" haciendo énfasis en el peligro que conlleva abrirse a la alteridad bajo el argumento de que se ponen en riesgo tradiciones, creencias, lenguas, etc., pues si ese "otro" no está dispuesto a asimilarse a lo que se ofrece como parte "esencial" de una nación, entonces, ésta asume que no tiene la obligación y sí el "derecho" de rechazar a quien no esté dispuesto a integrarse a una sociedad que se presume homogénea.

Ese rechazo al "otro" desde un discurso hegemónico aparece como un recurso que se utiliza de manera frecuente por los estados para legitimar políticas que pongan en cuestión al que no está dentro su territorio o al que está pero no responde a patrones deseados, hay casos sobrados en este momento, por ejemplo: los mexicanos en Estados Unidos de América y los africanos en gran parte de Europa.

Las fronteras siguen siendo esa "herida abierta" porque todavía son escenarios de disputas y espacios de contención en los que los estados ponen en juego su aparato de seguridad para mostrar su rechazo al "otro", una exclusión selectiva que responde a factores como el color de piel, los ingresos económicos, el territorio de pertenencia, entre otros.

Gloria Anzaldúa vivió ese rechazo por no responder a lo que dictaba un discurso que legitimaba al patriarcado, al "gringo" y a una forma "correcta" de hablar. Por eso Borderlands/La Frontera... se ha vuelto un texto clave para observar y analizar el presente convulso en el que estamos, ya que en él se brinda un argumento que sigue vigente: no aceptar a los/las diferentes y las diferencias provoca dolor y marginación, ambos aspectos interpelan nuestro estado de derecho de manera constante. Por lo que sigue siendo una asignatura pendiente contrarrestar todas aquellas políticas y prácticas que denigran nuestra condición humana y la oprimen. 
Desde lo que testimonia Anzaldúa, las pugnas por la lengua no se han dejado de lado, y en Estados Unidos todavía hay un rechazo de algunos sectores hacia aquellos que no hablan un inglés "correcto". En este terreno, si bien los chicanos han ocupado importantes espacios, sobre todo a nivel político y académico, la lucha por su lengua sigue vigente.

Por otro lado, cuestionar estereotipos y prejuicios hacia las mujeres sigue siendo una tarea constante del feminismo. Anzaldúa profundiza esta crítica al exhibir cómo a través de los símbolos se refuerzan y justifican aspectos negativos de las mujeres, pero a través de un proceso de deconstrucción se pueden rastrear narrativas que contradicen esas características perniciosas.

De esta forma, la autora chicana apuesta por la construcción de narrativas abiertas hacia lo "extraño", lo "diferente", lo "anormal". Esta manera de teorizar rompe con la tendencia de los binarismos: racional/emocional, mujer/hombre, heterosexual/homosexual, normal/anormal, entre otros, y plantea el devenir como condición de nuestros imaginarios sociales. Lo cual implica asumir la imposibilidad de enmarcar las narrativas y discursos como herencias inamovibles. A partir de esto, "nación", "patriarcado", "raza" y "capitalismo" son términos que pierden la "naturalización" que por años los ha justificado. Por lo que, una vez que se remueven sus bases, comienzan a circular las voces "silenciadas", aquellas que agonizan bajo la sombra de las narrativas hegemónicas.

Finalmente, la propuesta de una "memoria Nepantla" contradice las versiones homogéneas sobre el pasado, pues esta memoria reconoce que es producto de muchas herencias. También cuestiona a aquellas memorias que no están abiertas a un debate, que se erigen como "verdad" y que reaccionan de manera dogmática ante el cuestionamiento. En definitiva, se trata de una apuesta por recoger los elementos que nos ayuden a alimentar narrativas más humanas, pues no se trata de excluir, sino de reconocer a esos "otros", porque al final de cuentas esa dicotomía "nosotros/otros" sólo 
Configuración de una "memoria Nepantla" en Borderlands...

Maestría en Historia y Memoria

Universidad Nacional de la Plata

ha profundizado la negación, el ocultamiento y la marginación de seres humanos. 


\section{Bibliografía}

\section{Libros y artículos de libros:}

- Aguirre, Pedro. (2001). Sistemas políticos y electorales contemporáneos: Estados Unidos. México: Instituto Federal Electoral.

- Alarcón, Norma. (1988). "La literatura feminista de la chicana: una revisión a través de Malintzin o Malintzin: devolver la carne al objeto". En Moraga, Cherrie y Castillo, Ana. Este puente, mi espalda (pp. 231241). San Francisco: Ismo.

- Anderson, Benedict. (1993). Comunidades imaginadas. Reflexiones sobre el origen y la difusión del nacionalismo. México: FCE.

- Anzaldúa, Gloria. (1987 y 2012). Borderlands/ La Frontera: The New Mestiza. San Francisco, Ca. Aunt Lute Books.

- Anzaldúa, Gloria. (2015). Borderlands/La Frontera: La nueva mestiza. México: UNAM.

- Anzaldúa, Gloria. (1988). "Hablar en lenguas. Una carta a escritoras tercermundistas". En Moraga, Cherrie y Castillo, Ana. Este puente, mi espalda (pp. 219-228). San Francisco: Ismo.

- Anzaldúa, Gloria. (1988). "La Prieta". En Moraga, Cherrie y Castillo, Ana. Este puente, mi espalda (pp. 157-168). San Francisco: Ismo.

- Arellano Aguilar, María Isabel. (1982). "El Movimiento Chicano". En Carlos García Moreno (comp.). Análisis de algunos problemas fronterizos y bilaterales entre México y Estados Unidos. México: UNAM. 
- Barnet, Miguel. (1997). Biografía de un Cimarrón. Buenos Aires: Centro Editor de América Latina. Recuperado de https://drive.google.com/file/d/OBxxGe5A9qhzfNTFmMjhjNDAtODZiO C00MDM2LWJkZDktYiZiZjVkMTRmZTRh/view?ddrp=1\&hl=es\#

- Bartra, Roger. (2006). La Jaula de la Melancolía. Identidad y metamorfosis del mexicano. México: Debolsillo.

- Belausteguigoitia Rius, Marisa. (2015). "Introducción" En Borderlands/La Frontera: la nueva mestiza (pp. 13-44). México: UNAM.

- Belausteguigoitia Rius, Marisa. (2015a). "Sandra Cisneros: la escritura como réplica en Caramelo o puro cuento, 'Ojos de Zapata' y ‘El arroyo de la Llorona". En Claire Joysmith (editora). Nepantla: liminalidad y transición: escritura chicana de mujeres (pp. 105-121). México: UNAM-CISAN.

- Bhabha, Homi. (2002). El Lugar de la Cultura. Buenos Aires: Manantial.

- Bhabha, Homi. (2000). "Narrando la nación". En Fernández, Álvaro (comp) La invención de la nación. Lecturas de la identidad de Herder a Homi Bhaba (pp. 211-219). Buenos Aires: Manantial.

- Blackwell, Maylei. (2008). "Las hijas de Cuauhtémoc: feminismo chicano y prensa cultural 1968-1973". En Suárez Navas, Liliana y Hernández Castillo, Rosalva. Descolonizando el feminismo: teorías prácticas de los márgenes. Recuperado de

http://www.reduii.org/cii/sites/default/files/field/doc/Descolonizando\%2 0el\%20feminismo.pdf

- Campos Rodríguez, Lilia; Rodríguez-Shadow, María. (2011). "Concepciones sobre las sexualidades de las mujeres entre los aztecas". En Género y sexualidad en el México antiguo (pp.99-118). Puebla: Centro de Estudios de la Antropología de la Mujer. 
- Cantú, Norma y Hurtado, Aída. (2012). "Breaking Borders/ Constructing Bridges: Twenty-Five Years of Borderlans/La Frontera". En Borderlands/La Frontera: The New Mestiza (pp. 3-13).

- Cantú, Norma Elia. (2015). "Traducir: abrir caminos, construir puentes". En Borderlands/La Frontera: la nueva mestiza (pp. 45-57). México: UNAM.

- Castro-Gómez, Santiago y Grosfoguel, Ramón. (2007). El giro decolonial. Reflexiones para una diversidad epistémica más allá del capitalismo global. Bogotá: Siglo del hombre editores. Recuperado de http://www.unsa.edu.ar/histocat/hamoderna/grosfoguelcastrogomez.p df

- Castronovo, Russ. (2003). "Narrativas comprometidas a lo largo de la frontera; La línea Mason-Dixon, la resistencia y la hegemonía." En Scott y Johnson. Teoría de la Frontera. Los límites de la política cultural. Barcelona: Gedisa.

- Cohen, Esther. (2006). Los narradores de Auschwitz. Monterrey: Fineo.

- Derrida, Jacques. (1997). "La Farmacia de Platón". En La Diseminación (pp. 91-261). Madrid: Espiral.

- Real Academia Española. (2014). Diccionario de la Lengua Española. https://dle.rae.es/?id=JYOQ3cz

- Eco, Umberto. (2009). Apocalípticos e Integrados. México: Tusquets.

- Fonseca Ibarra, Enah Montserrat. (2011). "¿Ideales femeninos? Un acercamiento a la identidad de género de teotihuacanos y mexicas". En López Hernández y Rodríguez-Shadow (eds.). Género y sexualidad en el México antiguo (pp. 75-97). Puebla: Centro de Estudios de la Mujer. 
- Freire, Paulo. (2005). Pedagogía del Oprimido. México: Siglo XXI.

- García Canclini, Néstor. (2009). Culturas Híbridas. Estrategias para entrar y salir de la modernidad. México: Random House Mondadori.

- Gellner, Ernest. (2001). Naciones y nacionalismo. Madrid: Alianza.

- Grimson, Alejandro. (2003). "Introducción" En Scott, M. y Johnson, D. Teoría de la Frontera. Los límites de la política cultural. Barcelona: Gedisa.

- Grimson, Alejandro. (2011). Los límites de la cultura. Crítica de las teorías de la identidad. Buenos Aires: Siglo XXI.

- Halbwachs, Maurice. (2004) La memoria colectiva. Zaragoza: Universidad de Zaragoza.

- Hernández, Guillermo. (1993). La sátira chicana. México: Siglo XXI.

- Hernández-Gutiérrez, Manuel de Jesús. (1994). El colonialismo interno en la narrativa chicana. Arizona: Editorial Bilingüe.

- Herrera Carassou, Roberto. (2006). La perspectiva teórica en el estudio de las migraciones. México: Siglo XXI.

- Hobsbawm, Eric. (1998). Naciones y nacionalismo desde 1780. Barcelona: Mondadori.

- Hooks, Bell. (2017). El feminismo es para todo el mundo. Madrid: Traficantes de sueño. Recuperado de https://www.traficantes.net/sites/default/files/pdfs/TDS map47 hooks web.pdf

- Ikas, Karin. (2012). "Interview with Gloria Anzaldúa". En Anzaldúa, Gloria. Borderlands/La Frontera... (pp. 267-284). San Francisco: Aunt Lute Books. 
- Jelin, Elizabeth. (2005). "Exclusión, memorias y luchas políticas". En Daniel Mato. Cultura, política y sociedad. Perspectivas Latinoamericanas (pp. 219-239). Buenos Aires: CLACSO. Recuperado de

http://bibliotecavirtual.clacso.org.ar/ar/libros/grupos/mato/Jelin.rtf

- Joysmith, Claire. (2015). "Nepantla y escritura chicana". En Nepantla: liminaridad y tradición. Escritura chicana de mujeres (pp. 11-26). México: UNAM-CISAN.

- Keating, Ana Louise. (2009). The Gloria Anzaldúa readers. United of America: Duke University Press.

- Kuhn, Thomas. (2013). La estructura de las revoluciones científicas. México: FCE.

- Lafaye, Jacques. (1993). Quetzalcóatl y Guadalupe. La formación de la conciencia nacional en México. México: FCE.

- Leal, José Luis. (2000). "El concepto Aztlán en la poesía Chicana”. En Valenzuela Arce, José Manuel. Entre la magia y la historia: tradiciones, mitos y leyendas de la frontera (pp. 215-230). Tijuana: Colegio de la Frontera Norte-Plaza y Valdés. Recuperado de https://books.google.com.mx/books?id=3KzXWFpTpv8C\&pg=PA215\& lpg=PA215\&dq=Aztl\%C3\%A1n+mito+chicano\&source=bl\&ots=SF1Zf6 HVI7\&sig=BLNgwi1RlylP5bd8emJVZ1 rphAo\&hl=es\&sa=X\&ved=0ahU KEwjH1sundLKAhUDLyYKHc98CYEQ6AEILDAD\#v=onepage\&q=Aztl\%C3\%A1n $\% 20$ mito $\% 20$ chicano\&f=false

- León-Portilla, Miguel. (1980). Toltecayotl, aspectos de la cultura náhuatl. México: FCE.

- León-Portilla, Miguel. (2000). Tonantzin Guadalupe. Pensamiento náhuatl y mensaje cristiano en el "NicanMopohua". México: FCEColegio de México. 
- León-Portilla, Miguel. (2002). Memoria Azteca de la Conquista. México: Planeta-CONACULTA.

- Lienhard, Martín. (2003) La voz y su huella. México: Casa Juan Pablo.

- Lipski, John. (1985). Linguistic Aspects of Spanish-English. Language Switching. Tempe: Arizona State University, Center for Latin American Studies.

- Marginson, Simon y Ordorika, Imanol. (2010). Hegemonía en la era del conocimiento. México: UNAM.

- Mariátegui, José Carlos. (2000). "El florecimiento de las literaturas nacionales". En Fernández, Álvaro (comp) La invención de la nación. Lecturas de la identidad de Herder a Homi Bhaba (pp. 67-73). Buenos Aires: Manantial.

- Martín-Rodríguez, Manuel. (2006). La voz urgente. Antología de la literatura chicana en español. España: Fundamentos.

- Mignolo, Walter. (2003). Historias Locales/Diseños Globales. Madrid: AKAL.

- Mignolo, Walter. (2007). "El pensamiento decolonial: desprendimiento y apertura. Un manifiesto". En Castro Gómez, Santiago y Grosfoguel, Ramón. El giro decolonial. Reflexiones para una diversidad epistémica más allá del capitalismo global (pp. 25-46). Bogotá: Siglo del Hombre Editores.

- Miralles, Juan. (2004). La Malinche. México: Tusquets.

- Moraga, Cherríe. (1988). "La güera". En Este puente mi espalda (pp. 19-28). San Francisco: Ismo.

- Navarrete, Federico. (2004). Las relaciones interétnicas en México. Ciudad de México: UNAM. 
- Núñez, Cecillia. (2015). "Queering Nepantla: escritura ritual y performatividad fronteriza en Borderlands/La Frontera". En Claire Joysmith (editora). Nepantla: liminalidad y transición: escritura chicana de mujeres (pp. 73-88). México: UNAM-CISAN.

- Núñez Becerra, Fernando. (2002). La Malinche: de la historia al mito. México: INAH.

- Parekh, Bhikhu. (2000). "El etnocentrismo del discurso nacionalista". En Fernández, Álvaro (comp) La invención de la nación. Lecturas de la identidad de Herder a Homi Bhaba (pp. 91-122). Buenos Aires: Manantial.

- Pastrana Flores, Miguel. (2009). Historias de las conquistas. Aspectos de la historiografía de tradición náhuatl. México: UNAM.

- Paz, Octavio. (1950 y 2004). El Laberinto de la Soledad. México: FCE.

- Pollak, Michael. (2006). Memoria, olvido y silencio. La Plata: Al Margen.

- Poniatowska, Elena. (2015). "Escritoras chicanas y mexicanas". En Claire Joysmith (editora). Nepantla: liminalidad y transición: escritura chicana de mujeres (pp. 29-32). México: UNAM-CISAN.

- Prieto Stambaugh, Antonio. (2015). "Gloria Anzaldúa: epistemóloga del Nepantla". En Claire Joysmith (editora). Nepantla: liminalidad y transición: escritura chicana de mujeres (pp. 61-71). México: UNAMCISAN.

- Quijano, Aníbal. (1988). Modernidad, identidad y utopía en América Latina. Lima: Sociedad y Política.

- Ramírez, Alex. (2008). "Chicanas y chicanos: dos facetas de la migración". En Galeana, Patricia (edit.). La migración México-Estados Unidos y su feminización. México: UNAM. 
- Ranciére, Jacques. (2002). El Maestro ignorante. Barcelona: Laertes.

- Renan, Ernest. (2010). “¿Qué es una nación?”. En Bhabha, Homi. Nación y Narración (pp. 21-38). Argentina: Siglo XXI.

- Rodríguez Tapia, Stella Maris; Verduzco Argüelles y Gabriel Ignacio. (2009). "La Llorona: análisis literario-simbólico". En López, Teresa y Moreno, Fernando (eds). Ensayos sobre ciencia ficción y literatura fantástica: actas del Primer Congreso Internacional de literatura fantástica y ciencia ficción (pp. 306-318). Madrid: Asociación Cultural Xafati. Recuperado de https://e-archivo.uc3m.es/handle/10016/8675\#preview

- Ruiz, Vicki. (2008). From out of the shadows. Mexican women in Twentieth-Century America. New York: Oxford.

- Scott, Michaelsen y Johnson, David. (2003). Teoría de la Frontera. Los límites de la política cultural. Barcelona: Gedisa.

- Senemi, Yolotl. (2015) Andar en huaraches. Aguascalientes: Cerromuerto.

- Steiner, George. (2007). Logocratas. México: FCE-Siruela.

- Tabuenca Córdoba, María Socorro. (2015). "Borderlands/La Frontera de Gloria Anzaldúa. 'Que veinte años no es nada': una relectura desde mi Nepantla"' (pp. 89-102). En Claire Joysmith (editora). Nepantla: liminalidad y transición: escritura chicana de mujeres. México: UNAM-CISAN.

- Todorov, Tzvetan. (2000). Los abusos de la memoria. Buenos Aires: Paidós.

- Touraine, Alain. (1994). Crítica a la modernidad. Buenos Aires: FCE.

- Traverso, Enzo. (2007). "Historia y memoria. Notas sobre un debate". En Franco Mariana y Levín, Florencia (com.). Historia reciente. 
Configuración de una "memoria Nepantla" en Borderlands...

Maestría en Historia y Memoria

Universidad Nacional de la Plata

Perspectivas y desafíos para un campo en construcción. Buenos Aires: Paidós.

- Vallejo, César. (1984). "El Tungsteno-Paco Yunque”. Barcelona: Laia. Recuperado de

http://www.biblioteca.fundacionbbva.pe/libros/libro 000036.pdf

- Vasconcelos, José. (1948). La Raza Cósmica. Recuperado de http://www.turemanso.com.ar/larevista/bajadas/larazacosmica.pdf

- Vezzetti, Hugo. (2002). Pasado y presente. Buenos Aires: Siglo XXI.

- Vezzetti, Hugo. (2009). Sobre la violencia revolucionaria: memorias y olvidos. Buenos Aires: Siglo XXI.

- Villanueva Nieves, Natalia. (2015). "Un rebozo tecnicolor: memoria transcultural en Caramelo de Sandra Cisneros". En Claire Joysmith (editora). Nepantla: liminalidad y transición: escritura chicana de mujeres (pp. 123-136). México: UNAM-CISAN.

- Vizcarra, Fernando. (2005). "En busca de la frontera. Identidades emergentes y migración. Apuntes para una aproximación reflexiva". En La frontera interpretada. Procesos culturales en la frontera noroeste de México. Mexicali: CONACULTA.

\section{Artículos de revistas y online}

- Alarcón, Norma. "Anzaldúa's Frontera: Inscribing Gynetics". Anuario de Letras Modernas, Vol. 6 (1993-1994). Recuperado de http://teorialiteraria.filos.unam.mx/mis archivos/u8/02 alarcon.pdf

- Amezcua Gómez, David. (2016). La noción de tercer país en Borderlands/La Frontera como metáfora de la escritura transfronteriza de Gloria Anzaldúa. Actio nova: Revista de Teoría de la Literatura y Literatura Comparada, Núm. 0. 
DOI: http://dx.doi.org/10.15366/actionova2016.0

- Anzaldo-González, Demetrio. (2016). Coatlicue, la piedra, la palabra: Somos indias. En Los recuerdos del porvenir y Borderlands/La Frontera: The New Mestiza. Revista de Filología y Lingüística, Vol. 42 (Número especial), 131-144. DOI: 10.15517/RFL.V42I10.26470

- Arreola Martínez, Betzabé. (2009). Vida y obra de José Vasconcelos: el caudillo cultural de la nación. Casa del Tiempo, Vol. III ( 25), 4-10. Recuperado de http://www.uam.mx/difusion/casadeltiempo/25 iv nov 2009/casa del tiempo elV num25 04 10.pdf

- Basile, Teresa y Trigo, Abril. (2015). Las tramas de la memoria. Introducción. Alter/nativas, Núm. 5, 1-11. Recuperado de https://alternativas.osu.edu/es/index.html

- Belausteguigoitia Rius, Marisa. (2009). Borderlands/La Frontera: el feminismo chicano de Gloria Anzaldúa desde las fronteras geoculturales, disciplinarias y pedagógicas. Debate Feminista, Recuperado de

- http://www.debatefeminista.cieg.unam.mx/wpcontent/uploads/2016/03 larticulos/040 11.pdf

- Belausteguigoitia Rius, Marisa. (2009). Límites y fronteras: la pedagogía del cruce y la transdisciplina en la obra de Gloria Anzaldúa. Estudios Feministas, Vol. 17 (3), 755-767.

DOI: org/10.1590/S0104-026X2009000300008

- Betti, Silvia. (2016). Una cuestión de identidad... español y spanglish en los Estados Unidos. Camino Real: estudios de las hispanidades norteamericanas, Vol. 8 (11), 61-76. Recuperado de https://ebuah.uah.es/dspace/handle/10017/29102

- Betti, Silvia. (2010). Spanglish ¿Pseudolengua o identidad? Estudios de Lingüística Aplicada, Núm. 52, 29-59. Recuperado de 
Configuración de una "memoria Nepantla" en Borderlands...

Maestría en Historia y Memoria

Universidad Nacional de la Plata

\section{http://ela.enallt.unam.mx/index.php/ela/article/view/507/537}

- Carrasco, Pedro. (1975). La transformación de la cultura indígena durante la Colonia. Historia Mexicana, Vol. 25 (2), 175-203. Recuperado de

http://historiamexicana.colmex.mx/index.php/RHM/article/view/2833/2 $\underline{343}$

- Cacheux Pulido, Elena Margarita. (2003). Feminismo chicano: raíces, pensamiento político e identidad de las mujeres. Reencuentro, Núm. 37, 43-53. Recuperado de

http://www.redalyc.org/pdf/340/34003706.pdf

- Carroll, Patrick James. (1995). Los mexicanos negros, el mestizaje y los fundamentos olvidados de la 'Raza Cósmica': una perspectiva regional. Historia Mexicana, Vol. 44 (3), 403-428. Recuperado de http://historiamexicana.colmex.mx/index.php/RHM/article/view/2295/1 $\underline{901}$

- Chinchilla Sánchez, Kattia. (2015). Jano: el dios de los inicios y el dios de las puertas. Filología y Lingüística, Vol. 26 (1), 227-241. DOI: 10.15517/RFL.V26I1.21013

- Cortázar Rodríguez, Francisco Javier. (2004). Chicanos y mexicoamericanos en tres comunidades electrónicas. Comunicación y Sociedad, Núm. 2, 125-159. Recuperado de http://www.redalyc.org/pdf/346/34600206.pdf

- Crisco, Virginia. (2204). Rethinking language and culture on the institutional borderland. Journalof Basic Writing, Vol. 3 (1), 39-63 Recuperado de https://files.eric.ed.gov/fulltext/EJ684121.pdf

- Cruz Prados, Alfredo. (1995). Sobre los fundamentos del nacionalismo. Revista de Estudios Políticos (Nueva Época), Núm. 88, 199-221. Recuperado de 
Configuración de una "memoria Nepantla" en Borderlands...

Maestría en Historia y Memoria

Universidad Nacional de la Plata

https://recyt.fecyt.es/index.php/RevEsPol/article/view/46819/28303

- Delhalle, Jean-Claude; Luykx, Albert. (1992). Coatlicue o la degollación de la madre. Indiana, Vol. 12, 15-20.

DOI: http://dx.doi.org/10.18441/ind.v12i0.15-20

- Díaz Barriga, Miguel. (2002). Repensando a la Virgen de Guadalupe: devoción, empoderamiento e identidad masculina chicana. Alteridades, Vol. 12 (23), 35-47. Recuperado de http://www.redalyc.org/articulo.oa?id=74702304

- Erlij, David. (2005). Un hombre asustado. Letras Libres, Núm. 77. Recuperado de https://www.letraslibres.com/mexico/precursoras-la-democracia-en$\underline{\text { mexico }}$

- Ferro Vida, Luis Enrique. (2017). La voz y su huella de Martín Lienhard. Boletín de Antropología Universidad de Antioquia, Vol. 32 (54), 298-302. Recuperado de https://www.redalyc.org/pdf/557/55752394013.pdf

- García Canclini, Néstor. (1997). Culturas híbridas y estrategias comunicacionales. Estudios sobre las culturas contemporáneas, Vol. III (5), 109-128. Recuperado de http://www.redalyc.org/articulo.oa?id=31600507

- García Peña, Lilia Leticia. (2012). Nociones esenciales para el análisis de símbolos en los textos literarios. Teoría de la literatura y literatura comparada. Recuperado de

https://ddd.uab.cat/pub/452f/452f a2012n6/452f a2012n6p124iSPA.p df

- Garduño, Everardo. "Antropología de la frontera, la migración y los procesos transnacionales". Revista Internacional de Fronteras, Núm. 30, 2003, Colegio de la Frontera Norte. Recuperado de https://ojs.colef.mx/index.php/fronteranorte/article/view/1511/959 
- Gewecke, Frauke. (1996). La literatura chicana entre resistencia, transgresión y asimilación. Notas: Reseñas Iberoamericanas. Literatura, Sociedad, Historia, Vol. 3 (3), 2-47. Recuperado de https://www.jstor.org/stable/43116499?read$\underline{\text { now}=1 \& \text { loggedin=true\&seq=1\#page scan tab contents }}$

- Godínez Rivas, Gloria Luz. (2017). Lloronas, madres y fantasmas: necrobarroco en México. Estudios de género del Colegio de México, Vol. 3 (5), 129.163. Recuperado de http://estudiosdegenero.colmex.mx/index.php/eg/article/view/120

- Godínez Rivas, Gloria Luz. (2014). Mujer-serpiente en México. De Cihuacóatl a Lukas Avendaño. Amerika. Recuperado de https://journals.openedition.org/amerika/5314

- Gómez Carro, Carlos. (2001). Huichilopoztli y Guadalupe: la simétrica reinvención del mito. Casa del Tiempo. Recuperado de http://www.uam.mx/difusion/revista/julago2001/gomez.pdf

- González Manrique, Manuel Jesús. (2013). El 'estigma de Eva' en la leyenda mexicana la llorona. Revista de Antropología Experimental, Núm. 13, 541-556. Recuperado de

https://revistaselectronicas.ujaen.es/index.php/rae/article/view/1843/1 $\underline{599}$

- González, Rodolfo. (1969). El Plan Espiritual de Aztlán. Recuperado de

\section{http://clubs.arizona.edu/ mecha/pages/PDFs/EIPlanDeAtzlan.pdf}

- Guerrero Velázquez, Carlos Alberto. (2013). El Mestizaje en el Tepeyac y la construcción discursiva de una hierofanía en el comienzo del despertar poscolonial. Espacio e Cultura, Núm.34, 151172. Recuperado de http://www.epublicacoes.uerj.br/index.php/espacoecultura/issue/view/839/showToc 
- Gussinyer i Alfonso, Jordi. (1996). Sincretismo, religión y arquitectura en Mesoamérica (1521-1571). Boletín Americanista, Núm. 46, 187241. Recuperado de

https://dialnet.unirioja.es/servlet/autor?codigo $=1261175$

- Gutiérrez, Ramón. (1993). Community, patriarchy and individualism: The politics of Chicano history and the dream of equality. American Quarterly, Vol. 45 (1), 44-72. DOI: 10.2307/2713052

- Gutiérrez Magallanes, María del Socorro. (2018). Gloria Anzaldúa y el giro descolonial desde la frontera para el mundo. Camino Real, Vol. 10 (13), 79-89. Recuperado de https://ebuah.uah.es/dspace/handle/10017/33752

- Hernández Castillo, Rosalva Aída. (2003). Posmodernismos y feminismos: diálogos, coincidencias y resistencias. Desacatos, Núm.13, 107-121. DOI: https://doi.org/10.29340/13.1109

- Lakhtikov, Anastasia. (2017). Code-Switching in Anzaldúa's Borderlands/La Frontera and Walcott's Omeros: A Literary Device for New Readability. Poroi. An Interdisciplinary Journal of Rhetorical Analysis and Invention, Vol. 13, 1-30. DOI:10.13008/2151-2957.1239

- Lamas, Marta. (2012). Mujeres, aborto e iglesia católica. Nueva época, Núm. 3. Recuperado de http://ojs.colsan.edu.mx/index.php/COLSAN/article/view/517

- Lipski, John. (2003). La lengua española en los Estados Unidos: avanza a la vez que retrocede. Revista Española de Lingüística, Núm. 2, 231-260. Recuperado de http://www.sel.edu.es/pdf/jul-dic-03/01LIPSKI.pdf

- Lockhart, Tara. (2007). Writing the Self: Gloria Anzaldúa, Textual Form, and Feminist Epistemology. Michigan feminist studies, Vol. 20. Recuperado de 
Configuración de una "memoria Nepantla" en Borderlands...

Maestría en Historia y Memoria

Universidad Nacional de la Plata

- https://quod.lib.umich.edu/cgi/t/text/text-

idx?cc=mfsfront; $\mathrm{c}=\mathrm{mfs} ; \mathrm{c}=\mathrm{mfsfront} ; \mathrm{idno}=\mathrm{ark} 5583.0020 .002 ; \mathrm{g}=\mathrm{mfs}$

$\mathrm{g} ; \mathrm{rgn}=$ main; $;$ iew=text; $\mathrm{xc}=1$

- Lotman, luri. (2002). El símbolo en el sistema de la cultura.

Forma y Función, núm. 15, 88-101. Recuperado de

http://www.redalyc.org/articulo.oa?id=21901505

- López Arámburo, María del Consuelo. (2010). Nacionalismo, religión y sexualidad en la frontera: Las visiones de Josefina Rendón Parra y Gloria Anzaldúa. Meyibó, Núm. 1, 123-149.

Recuperado de

http://iih.tij.uabc.mx/iihDigital/MeyiboCap/Num1/EnsayoNacionali smo\%20JRendonP.pdf

- Martin, Holly. (2005). Code-switching in US ethnic literature: multiple perspectives presented through multiple languages. Changing English, Vol. 12 (3), 403-415. DOI:

https://doi.org/10.1080/13586840500347277

- Martín, Luciana Mara. (2009). Borderlands/La Frontera, de Gloria Anzaldúa: la construcción de una nueva conciencia y el relato de la Historia. Espacios, Núm. 42, 135-139. Recuperado de

http://www.filo.uba.ar/contenidos/secretarias/seube/revistaespacios/art iculos42.html

- Morales Blouin, Egla. (1978). Símbolos y motivos nahuas en la literatura chicana. La Revista bilingüe, Vol. 5 (1/2), 99-106. Recuperado de

http://www.jstor.org/stable/25743762?seq=1\#page scan tab contents

- Morlley, Raúl. (1993). Entrevista a Derrida. Deconstrucción y Filosofía. Zona erógena, Núm. 14, 1-9. Recuperado de

http://www.mercaba.org/SANLUIS/Filosofia/autores/Contempor\%C3\% A1nea/Derrida/Deconstrucci\%C3\%B3n\%20y\%20filosof\%C3\%ADa.pdf 
- Nogues, Sylvie. (2005). El arroyo de la Llorona de Sandra Cisneros: recuperación y transformación chicanas de una leyenda mexicana. Actas del XXXV Congreso Internacional de la Asociación Europea de Profesores de Español, 63-72. Recuperado de

http://cvc.cervantes.es/ensenanza/biblioteca ele/aepe/pdf/congreso 3 5/congreso 35 09.pdf

- Ocaña Jiménez, Lucila. (2004). El laberinto de Quetzalcóatl. Estudios Políticos, Núm. 3, 61-98.

DOI: http://dx.doi.org/10.22201/fcpys.24484903e.2004.3.37629

- Poplack, Shana. (1980). Sometimes l'll start a sentence in Spanish y termino en Español: toward a typology of code-switching. Revista Linguistics, Núm. 18, 581-618. Recuperado de http://www.sociolinguistics.uottawa.ca/shanapoplack/pubs/articles/Pop lack1980Sometimes.pdf

- Prieto Osorno, Alexander. (2004). Spanglish: una patria, una identidad. Centro Virtual Cervantes. Recuperado de https://cvc.cervantes.es/el rinconete/anteriores/mayo 04/25052004 0 1.htm

- Rodríguez, Roberto. (1996). The Origins and History of the Chicano Movement. Occasional paper, Núm. 7, 1-8. Recuperado de https://jsri.msu.edu/upload/occasional-papers/oc07.pdf

- Sierra González, Angela. (2009). Una aproximación a la teoría queer: el debate sobre la libertad y la ciudadanía. Cuadernos del Ateneo, Núm. 26, 29-42. Recuperado de https://dialnet.unirioja.es/servlet/articulo?codigo $=3106547$

- Soberanes Fernández, José Luis y Vega Gómez, Juan. (1998). El Tratado de Guadalupe-Hidalgo en su sesquicentenario. Cuadernos Constitucionales México-Centroamérica. Recuperado de http://biblio.juridicas.unam.mx/libros/libro.htm?l=166 
Configuración de una "memoria Nepantla" en Borderlands...

Maestría en Historia y Memoria

Universidad Nacional de la Plata

- Spoturno, María Laura. (2005). La alternancia de códigos en la literatura chicana. Acta del III Coloquio Nacional de Investigadores en Estudios del Discurso, Recuperado de

https://es.scribd.com/document/70602358/ALTERNANCIA-DECODIGOS-EN-LA-LITERATURA-CHICANA

- Trigo, Abril. (1997). Fronteras de la epistemología: epistemologías de la frontera. Papeles de Montevideo, Núm. 1, 71-89. Recuperado de https://mediostamayo.files.wordpress.com/2013/10/fronteras de la e pistemologi.pdf

- Wierciński, Andrzej. (1985). Ometéotl-concepción de la deidad suprema en el México prehispánico. Revista de Estudios Latinoamericanos, Núm. 10, 9-32. Recuperado de http://www.ikl.org.pl/Estudios/EL10/EL10 1.pdf

- Zentella, Ana Celia. (1995). La hispanofobia del movimiento 'inglés oficial' en los Estados Unidos para la oficialización del inglés. Alteridades, Núm. 10, 55-65. Recuperado de https://alteridades.izt.uam.mx/index.php/Alte/article/view/563/561 